Australian

National

University

Crawford School of Public Policy

\title{
CAMA
}

Centre for Applied Macroeconomic Analysis

\section{Negative Interest Rate Policies: Sources and Implications}

\section{CAMA Working Paper 52/2016 August 2016}

\section{Carlos Arteta}

Development Prospects Group, World Bank

\section{Ayhan Kose}

Development Prospects Group, World Bank Brookings Institution

CEPR and

Centre for Applied Macroeconomic Analysis, ANU

\section{Marc Stocker}

Development Prospects Group, World Bank

Temel Taskin

Development Prospects Group, World Bank 


\section{Abstract}

Against the background of continued growth disappointments, depressed inflation expectations, and declining real equilibrium interest rates, a number of central banks have implemented negative interest rate policies (NIRP) to provide additional monetary policy stimulus over the past few years. This paper studies the sources and implications of NIRP. We report four main results. First, monetary transmission channels under NIRP are conceptually analogous to those under conventional monetary policy but NIRP present complications that could limit policy effectiveness. Second, since the introduction of NIRP, many of the key financial variables have evolved broadly as implied by the standard transmission channels. Third, NIRP could pose risks to financial stability, particularly if policy rates are substantially below zero or if NIRP are employed for a protracted period of time. Potential adverse consequences include the erosion of profitability of banks and other financial intermediaries, and excessive risk taking. However, there has so far been no significant evidence that financial stability has been compromised because of NIRP. Fourth, spillover implications of NIRP for emerging market and developing economies are mostly similar to those of other unconventional monetary policy measures. In sum, NIRP have a place in a policy maker's toolkit but, given their domestic and global implications, these policies need to be handled with care to secure their benefits while mitigating risks.

\section{Keywords}

Unconventional monetary policy, quantitative easing; bank profitability, financial stability, negative yields, event study, emerging markets, developing countries

\section{JEL Classification}

E52, E58, E60

\section{Address for correspondence:}

(E) cama.admin@anu.edu.au

ISSN 2206-0332

The Centre for Applied Macroeconomic Analysis in the Crawford School of Public Policy has been established to build strong links between professional macroeconomists. It provides a forum for quality macroeconomic research and discussion of policy issues between academia, government and the private sector.

The Crawford School of Public Policy is the Australian National University's public policy school, serving and influencing Australia, Asia and the Pacific through advanced policy research, graduate and executive education, and policy impact. 


\title{
Negative Interest Rate Policies: Sources and Implications"
}

\author{
Carlos Arteta, M. Ayhan Kose, Marc Stocker, and Temel Taskin
}

August 2016

\begin{abstract}
Against the background of continued growth disappointments, depressed inflation expectations, and declining real equilibrium interest rates, a number of central banks have implemented negative interest rate policies (NIRP) to provide additional monetary policy stimulus over the past few years. This paper studies the sources and implications of NIRP. We report four main results. First, monetary transmission channels under NIRP are conceptually analogous to those under conventional monetary policy but NIRP present complications that could limit policy effectiveness. Second, since the introduction of NIRP, many of the key financial variables have evolved broadly as implied by the standard transmission channels. Third, NIRP could pose risks to financial stability, particularly if policy rates are substantially below zero or if NIRP are employed for a protracted period of time. Potential adverse consequences include the erosion of profitability of banks and other financial intermediaries, and excessive risk taking. However, there has so far been no significant evidence that financial stability has been compromised because of NIRP. Fourth, spillover implications of NIRP for emerging market and developing economies are mostly similar to those of other unconventional monetary policy measures. In sum, NIRP have a place in a policy maker's toolkit but, given their domestic and global implications, these policies need to be handled with care to secure their benefits while mitigating risks.
\end{abstract}

JEL Codes: E52, E58, E60.

Keywords: Unconventional monetary policy, quantitative easing; bank profitability, financial stability, negative yields, event study, emerging markets, developing countries.

\footnotetext{
* Arteta (Development Prospects Group, World Bank; carteta@ worldbank.org); Kose (Development Prospects Group, World Bank; Brookings Institution; CEPR; CAMA; akose@ worldbank.org); Stocker (Development Prospects Group, World Bank; mstocker1@worldbank.org); Taskin (Development Prospects Group, World Bank; ttaskin@worldbank.org). We would like to thank Erdem Basci, Eduardo Borenzstein, Ajai Chopra, Stijn Claessens, Kevin Clinton, Charles Collyns, Christian Eigen-Zucchi, Erik Feyen, Jaime De Jesus Filho, Raju Huidrom, Ergys Islamaj, Eung Ju Kim, Jean Pierre Lacombe, Franziska Ohnsorge, Patrizio Pagano, Bryce Quillin, Modeste Some, Naotaka Sugawara, Dana Vorisek, many colleagues, and participants at seminars at the World Bank for their useful comments and suggestions. We are grateful to Mai Anh Bui and Peter Williams for outstanding research assistance. This Working Paper represents the views of the authors and does not necessarily represent World Bank Group views or policy. The views expressed herein should be attributed to the authors and not to the World Bank Group, its Board of Executive Directors, or its management.
} 

[In] the first full year with negative interest rates, [banks' net interest income] went up. [...] So all in all the [NIRP] experience has been positive.

Mario Draghi, April 2016

Negative nominal rates have reinforced forward guidance in the euro area, sped up the process of portfolio rebalancing ... and supported the effectiveness of the recent targeted longer-term refinancing operations.

Benoît Couré, July 2016

...overall, as a tool of monetary policy, negative interest rates

appear to have both modest benefits and manageable costs.

Ben Bernanke, March 2016

There are large benefits to being able to reduce the lower bound on the short-term nominal interest rate by as little as fifty basis points.

Narayana Kocherlakota, February 2016

The MPC is very clear that 'lower bound' is a positive number... I am not a fan of negative rates. We see the negative consequences through the financial system in other jurisdictions...

Mark Carney, August 2016

A decrease in the real interest rate to -3 or even -4 percent will make little or no difference, perhaps [...] exposing the economy to greater financial instability.

Joseph Stiglitz, April 2016

Zero or negative real interest rates, when they become quasi-permanent, undermine the efficient allocation of capital and set the stage for bubbles, busts, and crises.

Kemal Derviş, March 2016

Far from encouraging lending and spending, negative interest rates at the central bank might work in the opposite direction.

William White, December 2014 



\section{CONTENTS}

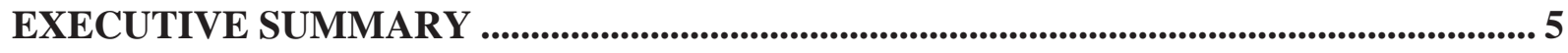

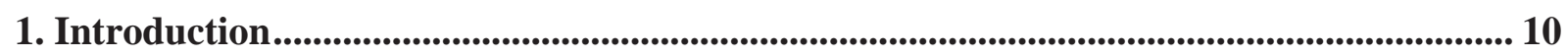

2. Why are some monetary policy rates negative? .............................................................. 13

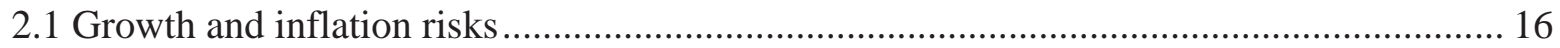

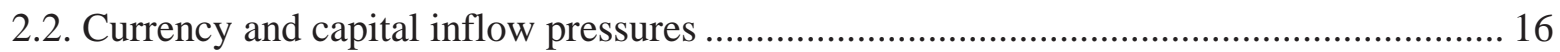

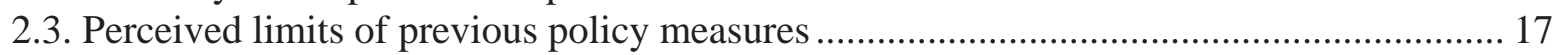

3. How do transmission channels of monetary policy operate under NIRP? ........................ 19

4. How have key financial variables evolved since the introduction of NIRP? ..................... 20

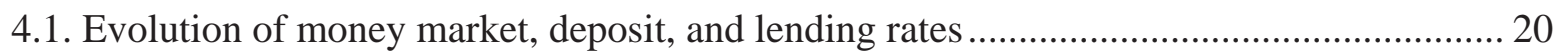

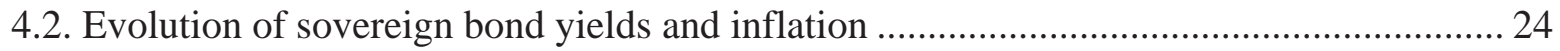

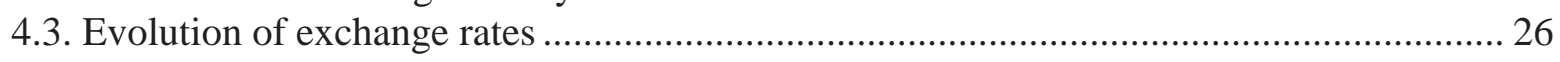

4.4. Initial reaction in financial markets to NIRP announcements: An event study ................. 26

4.5. Comparison of NIRP with other monetary policies in the euro area: An event study ....... 29

5. How could NIRP affect financial stability? ..................................................................................... 30

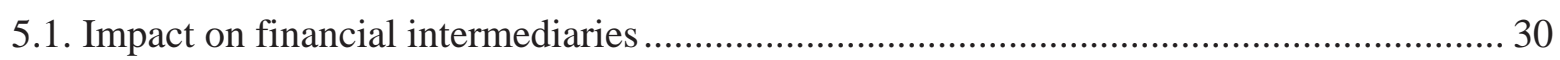

5.2. Changes in financial-sector variables following NIRP: An event study .......................... 35

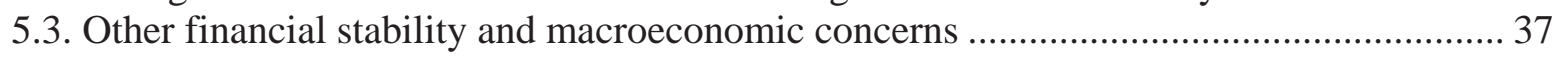

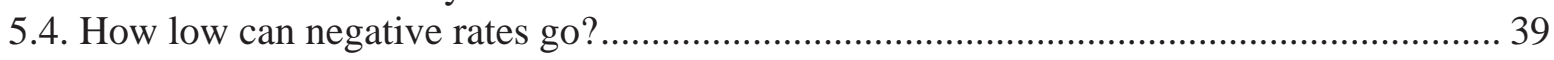

6. What are the implications of NIRP for emerging market and developing countries? .... 41

6.1. Potential impact on financing conditions for EMDEs................................................ 41

6.2. EMDE financial variables following NIRP announcements: An event study .................. 46

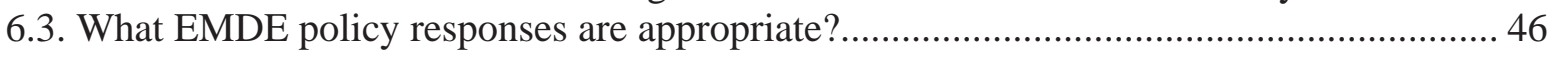

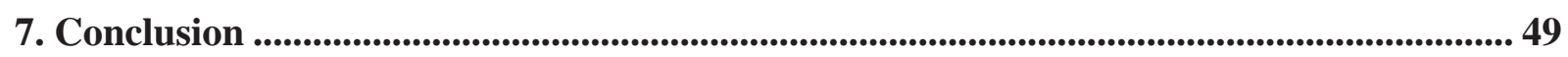

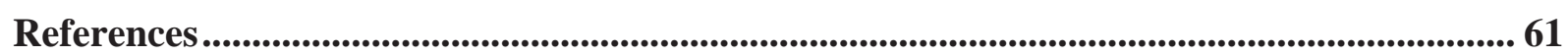

\section{TABLES}

Table 1. NIRP announcements and complementary policies.

\section{FIGURES}

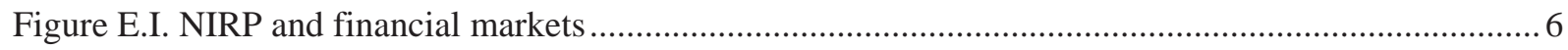

Figure E.II. NIRP, financial stability and emerging and developing economies ........................................ 8

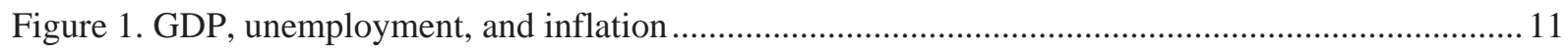

Figure 2. Policy interest rates and size of economies with negative rates ............................................... 12

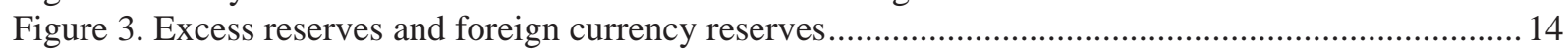

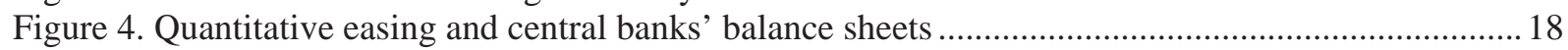

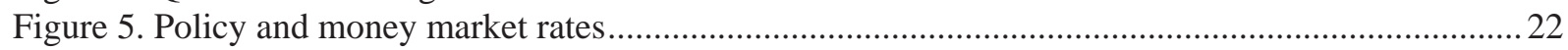

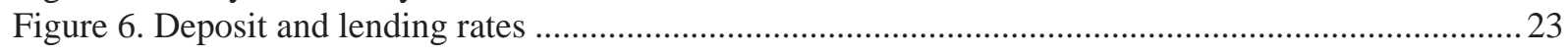

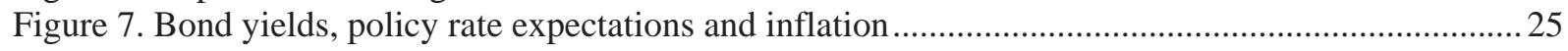


Figure 8. Exchange rates, yield differentials and foreign reserves ...................................................2 27

Figure 9. NIRP announcements: changes in selected financial variables over one-day window ...............28

Figure 10. ECB policy announcements: changes in selected financial variables over one-day window ....29

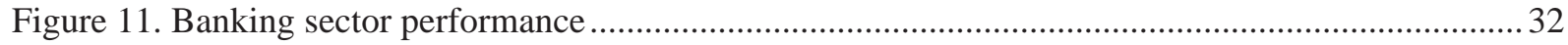

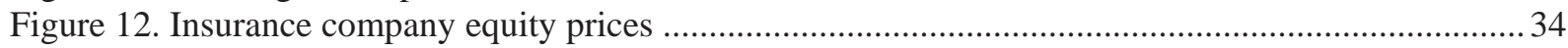

Figure 13. NIRP announcements: changes in financial sector variables over one-day window..................36

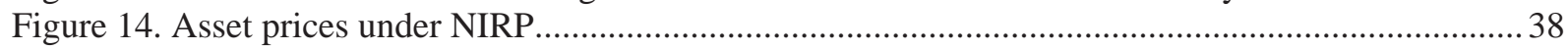

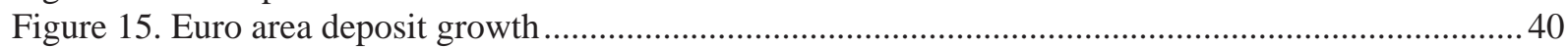

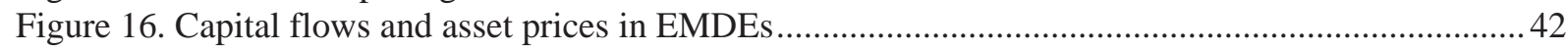

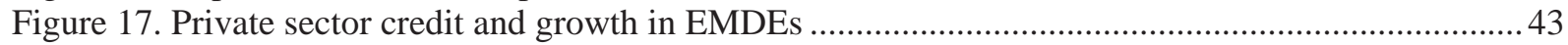

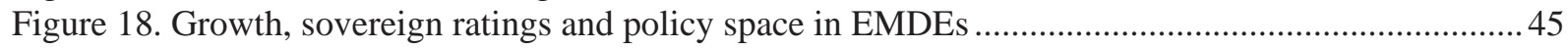

Figure 19. NIRP announcements: changes in EMDE financial variables over one-day window ...............47

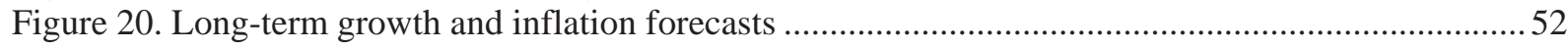

\section{ANNEXES}

Table A.1. Summary of the literature on the impact of QE policies

Table A.2. NIRP announcements: country-specific changes in selected financial variables over one-day

window

Table A.3. NIRP announcements: changes in EMDE financial variables over one-day window ..............59

Figure A.1. NIRP announcements: changes in selected financial variables up to one month ....................55 Figure A.2. NIRP announcements: country-specific changes in selected financial variables over one-day window.

Figure A.3. NIRP announcements: changes in financial sector variables up to one month ......................58

Figure A.4. NIRP announcements: changes in EMDE financial variables up to one month.......................60 


\section{EXECUTIVE SUMMARY}

Context: new frontier of unconventional monetary policy. A number of central banks, including the Danmarks Nationalbank (DNB), European Central Bank (ECB), Swiss National Bank (SNB), Swedish Riksbank, Bank of Japan (BoJ), and Central Bank of Hungary (MNB), have employed negative interest rate policies (NIRP) to provide additional monetary policy stimulus over the past few years (Figure E.I). These central banks are now charging (instead of paying) commercial banks for their excess reserves. The unprecedented use of NIRP in multiple countries, accounting together for one-fourth of world GDP, has not just extended the boundaries of unconventional monetary policies but also fueled an already polarized debate on the implications of these policies. This paper presents a comprehensive analysis of NIRP by exploring the reasons behind their implementation and examining their domestic and international implications. Specifically, the paper addresses the following questions:

- Why are some monetary policy rates negative?

- How do transmission channels of monetary policy operate under NIRP?

- How have key financial variables evolved since the introduction of NIRP?

- How could NIRP affect financial stability?

- What are the implications of NIRP for emerging and developing economies (EMDEs)?

Reasons behind NIRP: stabilize inflation expectations, support growth, and relieve currency pressures. The aforementioned central banks introduced NIRP to provide additional monetary policy accommodation in a context of continued growth disappointments, depressed inflation expectations, and declining real equilibrium interest rates. The use of NIRP aimed to show central banks' resolve to meet their policy objectives, as the perceived zero lower bound constrained their ability to commit to additional policy easing. In particular, the main motivation for the implementation of NIRP by the ECB, BoJ, Riksbank, and MNB was the need to stabilize inflation expectations and support growth. In the case of the SNB and DNB, an immediate motivation was the need to respond to currency appreciation and capital inflow pressures. For central banks implementing quantitative easing $(\mathrm{QE})$ policies, two additional considerations were the narrowing pool of assets eligible for their purchase programs and the possibility of diminishing returns from QE.

Transmission channels under NIRP: mostly standard, but more limited and with possibly unintended consequences. Transmission channels of monetary policy in the presence of NIRP are conceptually analogous to those under conventional monetary policy. Specifically, NIRP are expected to be transmitted mainly through the interest rate, credit, portfolio, and exchange rate channels. However, complications associated with these channels under NIRP could limit policy effectiveness, particularly if they have adverse effects on the financial sector. For example, in the case of the interest rate channel, commercial banks may hesitate to impose negative rates on depositors in order to prevent a loss of their deposit base. This downward rigidity in retail deposit 
Figure E.I. NIRP and financial markets

\section{A. Policy interest rates}

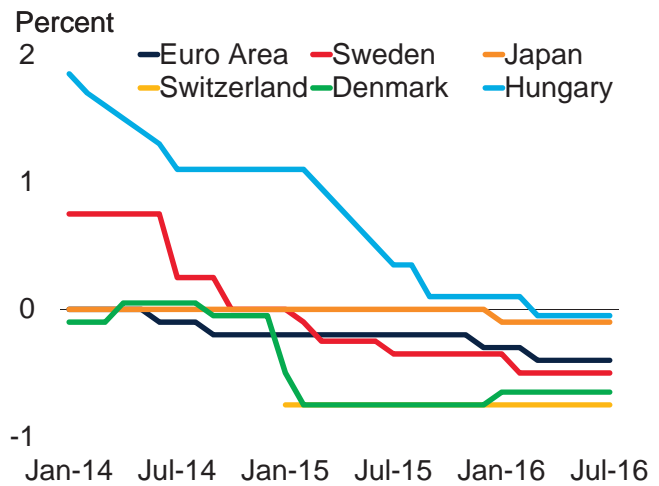

\section{Real equilibrium interest rates}

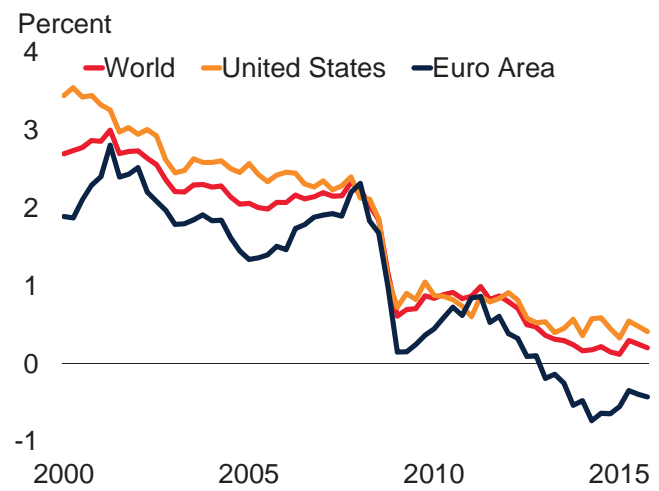

E. Money market rates and bond yields responses to NIRP announcements

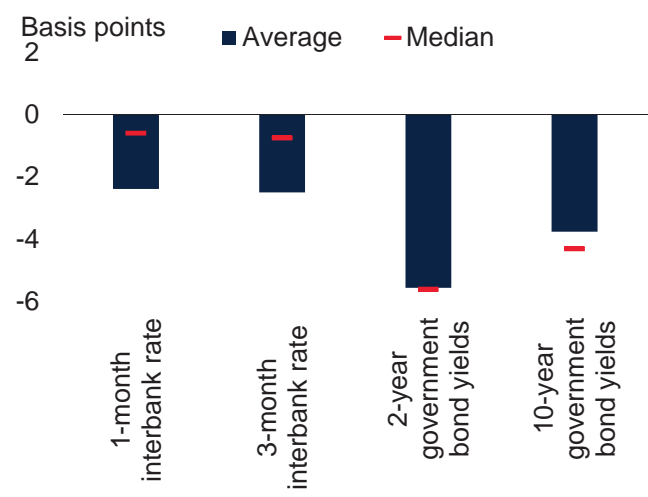

B. Size of economies with negative interest rates

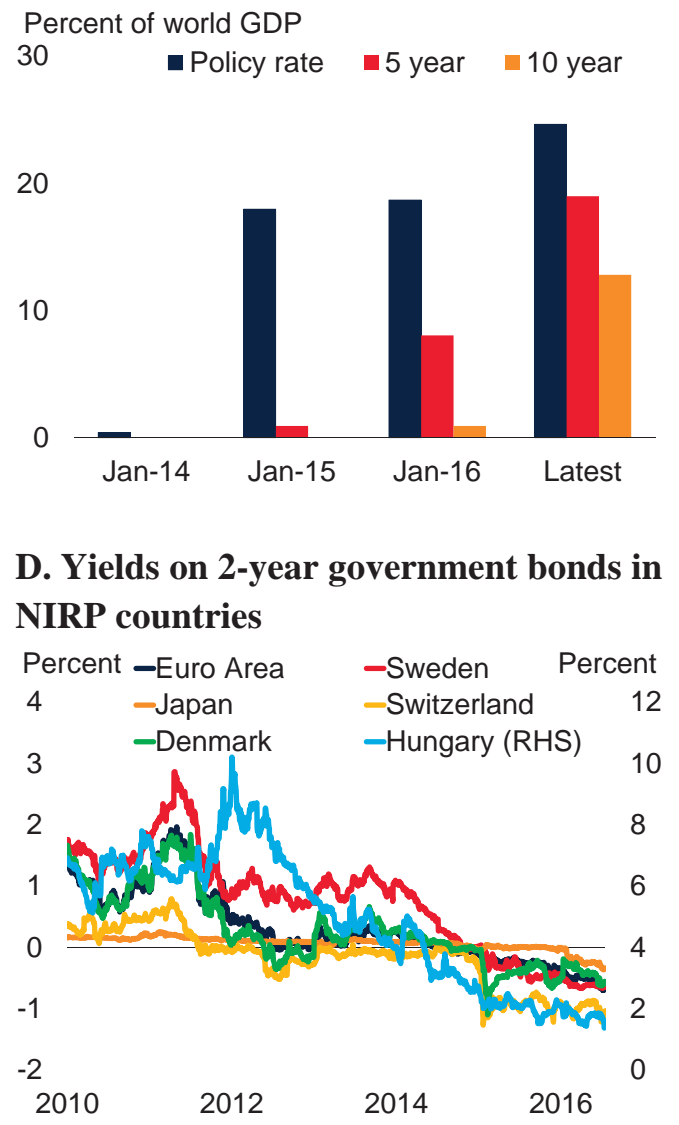

F. Money market rates and bond yields: responses to $\mathrm{ECB}$ policy announcements

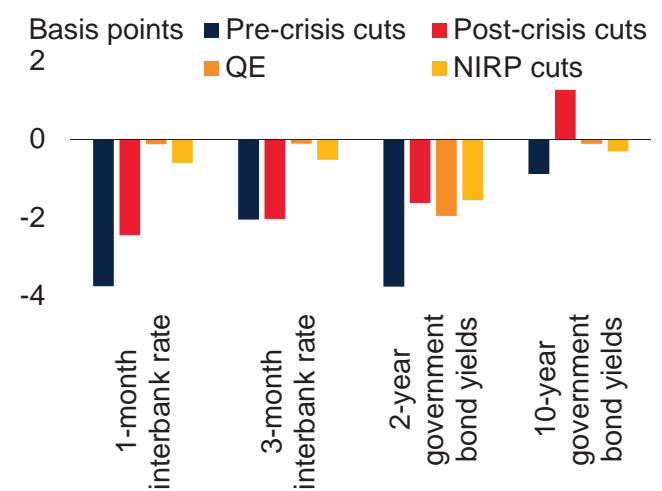

Sources: European Central Bank, Riksbank, Danmarks Nationalbank, Swiss National Bank, Bank of Japan, Central Bank of Hungary, Holston, Laubach and Williams (2016), Haver Analytics, Bloomberg, World Bank.

A: See notes of Figure 2.A; B: See notes of Figure 2.B; C: Real equilibrium interest rates are real policy interest rates consistent with a neutral monetary policy stance. Estimates are from Holston, Laubach and Williams (2016). World real rate is proxied by a GDP-weighted average of real equilibrium rates for the United States, euro area, United Kingdom and Canada. Last observation is 2015Q4; D: See notes of Figure 7.A; E: See notes of Figure 9.A.; F: See notes of Figure 10.A. 
rates may either limit the pass-through to lending rates, as banks seek to maintain interest margins, or adversely affect profitability, which could eventually weaken the transmission of monetary policy.

Evolution of key financial variables under NIRP: broadly as expected. Since the introduction of NIRP, key financial variables have evolved broadly as implied by the standard transmission channels of monetary policy. For example, policy rate cuts to negative levels have been generally reflected in corresponding declines in money market rates and short-term government bond yields. The fall in bank wholesale funding costs has helped lower lending rates, but to varying degrees across countries. The decline in rates on new loans has been particularly notable in the euro area, although other policy initiatives make the specific contribution of NIRP difficult to isolate, while the pass-through in other countries has been more limited. Inflation expectations have continued to decline in most NIRP economies. Currencies of countries implementing NIRP have on average depreciated since the corresponding policy decisions, with the exception of the marked appreciation of the Japanese yen and Swiss franc.

An event study indicates that money market rates and sovereign bond yields fall on the day of NIRP announcements, whereas inflation expectations do not change much and currency movements vary across countries. For the euro area, a comparison of the responses of key financial variables to announcements of NIRP, QE, and conventional interest rate cuts shows that the responses following NIRP are directionally consistent to those of conventional cuts, although on somewhat smaller. Overall, despite its potential drawbacks, NIRP appear to have helped deliver additional monetary stimulus in a challenging macroeconomic environment.

NIRP and financial stability: potential risks. NIRP could pose risks to financial stability, particularly if rates go substantially below zero or if NIRP are employed for a protracted period of time. Adverse outcomes could include the erosion of profitability of banks and other financial intermediaries and excessive risk taking. Available data so far provides inconclusive evidence of a significant impact of NIRP on bank profitability. While some bank surveys indicate a perception among survey participants that NIRP are having an adverse impact on bank profits, bank lending margins remain within post-crisis ranges and credit growth has improved, albeit sluggishly in most cases (Figure E.II). An event study also shows that the initial reaction of bank equity prices to NIRP announcements has been muted in most cases, while financial sector CDS spreads have generally declined on the announcement day.

Most central banks have introduced complementary policy measures to mitigate the potentially negative impact of NIRP on bank profitability. For example, in the case of the ECB, the implementation of NIRP was part of a package of measures including exceptionally favorable refinancing conditions for banks as well as expanded asset purchases. The BoJ, Riksbank, DNB, and SNB also implemented additional measures to alleviate pressure on bank earnings stemming from NIRP. 
Figure E.II. NIRP, financial stability and emerging and developing economies

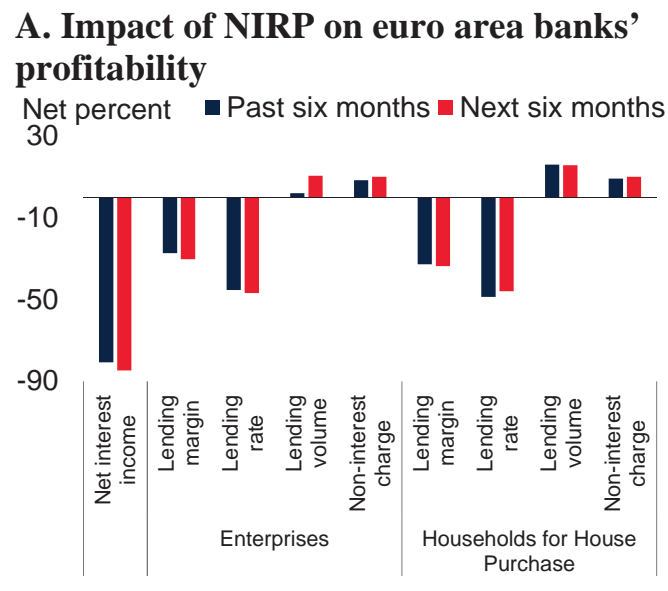

\section{Credit growth}

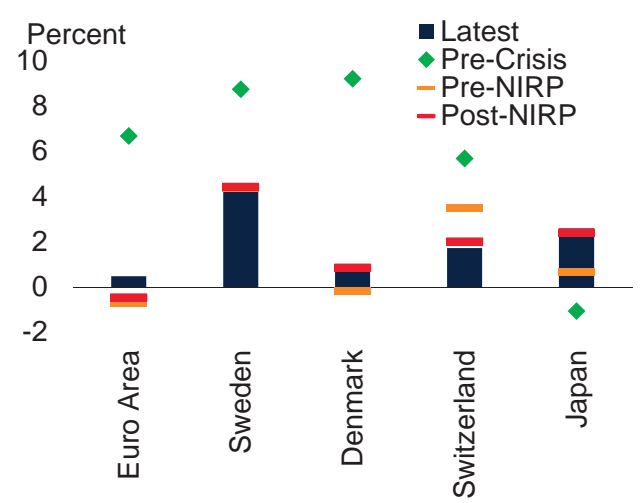

E. Share of capital inflows accounted by euro area residents

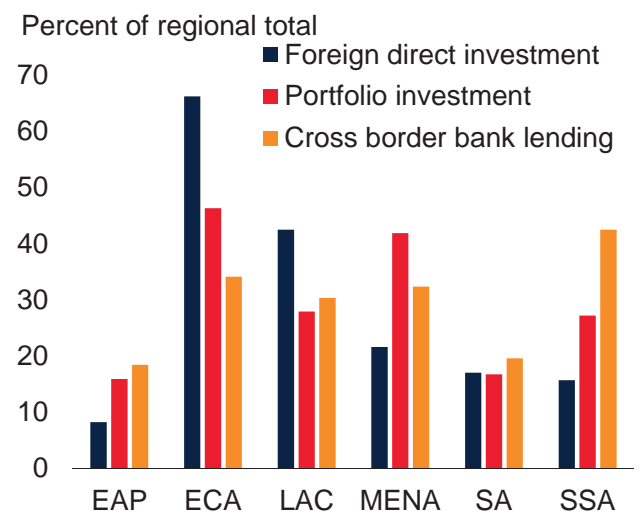

\section{B. Interest margins on household lending}

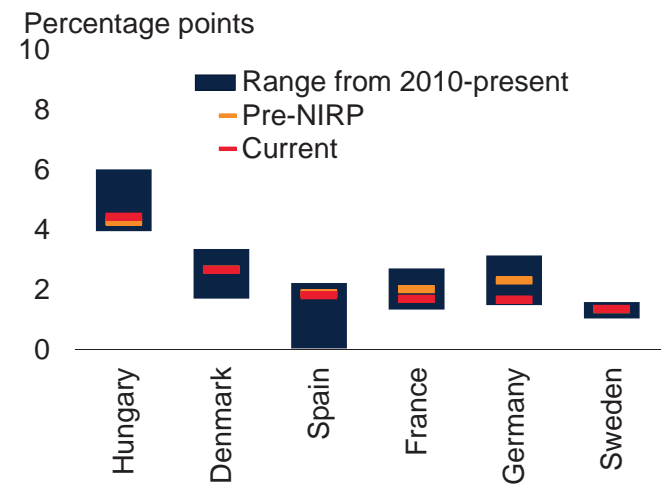

D. Financial sector asset prices: responses to NIRP announcements

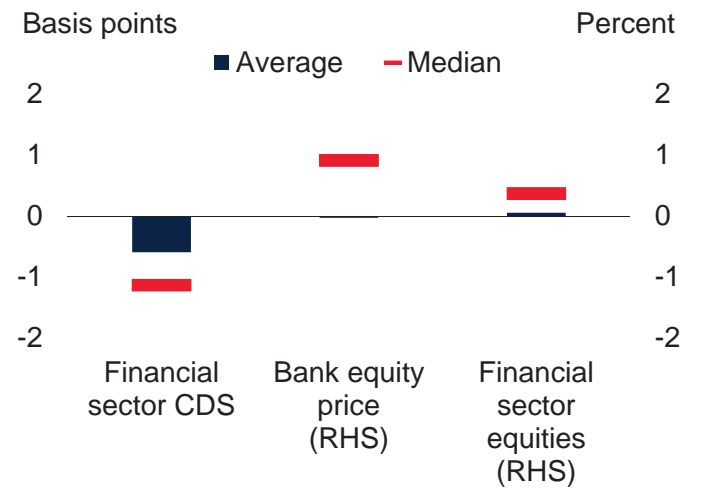

F. Emerging market asset prices: responses to NIRP announcements

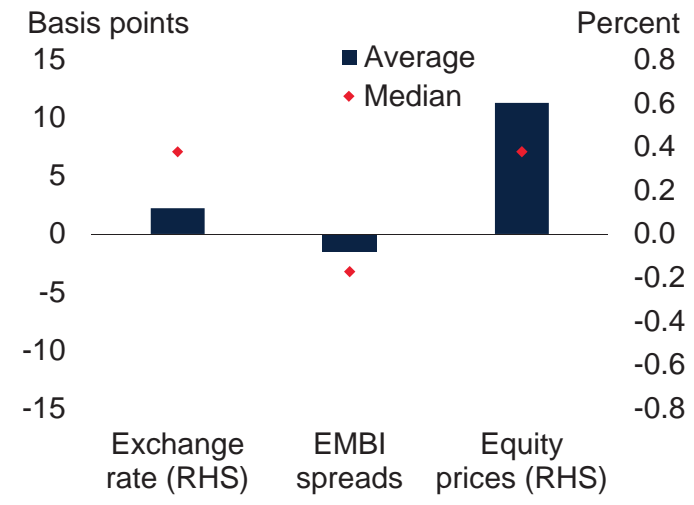

Sources: European Central Bank, Riksbank, Danmarks Nationalbank, Swiss National Bank, Bank of Japan, Haver Analytics, Bloomberg, World Bank.

A: See notes of Figure 11.A; B: See notes of Figure 11.D; C: See notes of Figure 11.F; D: See notes of Figure 13.A; E: See notes of Figure 16.E; F: See notes of Figure 19.A. 
With the rising share of negative-yielding debt securities, pension and life insurance companies could struggle to generate adequate returns to meet their long-term liabilities. Like other unconventional monetary policies, NIRP could also encourage excessive risk-taking, which could contribute over time to the formation of asset price bubbles. However, increases in house and equity prices have thus far remained moderate in most NIRP economies.

NIRP raise the question of how low negative rates can go before market distortions become significant enough to threaten financial stability. At the extreme, if central banks pushed policy rates too far into negative territory, there is a risk that large sectors of the economy could become cash-based. While some central banks have reduced their policy rates below -0.5 percent without any easily discernible financial market distortions, it is unclear whether rates could go much lower, or for a prolonged period, without raising financial stability concerns.

Impact of NIRP on EMDEs: benefits and risks. As the United States embarks on a gradual normalization of monetary policy, accommodative monetary policies, including NIRP, by other major central banks could help contain the ensuing increase in global interest rates and support demand for riskier, higher-yielding assets, including those of EMDEs. Regions that could benefit most directly from negative interest rates in the euro area include Europe and Central Asia, Latin America and the Caribbean, and Sub-Saharan Africa.

An event study shows that the responses of EMDE assets to NIRP announcements have been on average broadly consistent with expectations: currencies of EMDEs appreciated, bond spreads declined, and equity prices increased on the day of the announcement. The average impact on EMDEs is also qualitatively similar to those for QE policies by major central banks. While unconventional monetary policies, including NIRP, in advanced economies could have positive effects on global financial conditions, risks stemming from these policies could combine with domestic vulnerabilities and lead to disruptions in capital inflows to EMDEs. EMDEs should rebuild the necessary policy buffers and implement policies to mitigate the impact of volatile capital flows.

NIRP: securing benefits and mitigating risks. In an environment of weak growth, depressed real interest rates and low inflation expectations, NIRP can help provide additional monetary policy stimulus, as long as policy interest rates are only modestly negative and they do not stay negative for too long as to avoid lasting adverse effects on the financial sector. As such, negative policy interest rates have a place in a policy maker's toolkit but these policies need to be handled with care to secure their benefits while mitigating risks. 


\section{Introduction}

Major central banks cut their policy rates to or slightly above zero during the global financial crisis. As zero was then considered the lower bound for policy rates, further monetary easing was achieved through unconventional measures - such as forward guidance, asset purchase programs, and credit easing - to stimulate growth and stabilize inflation expectations. These policies led to a substantial decline in nominal and real interest rates, and helped support a slow and uneven recovery in economic activity (Figure 1$){ }^{1}$

However, spare capacity persisted in many advanced economies, both actual and expected inflation drifted below official targets, and downside risks to growth continued to dominate the outlook. Moreover, there was a perception of tight constraints on further policy easing, as policy rates were near zero, the net supply of eligible assets for central bank purchase programs was declining, and commercial banks were hoarding excess reserves rather than lending to households and companies.

Against this background, removing the perceived lower bound of policy interest rates was seen by some central banks as a necessary complement and amplifier of existing policy measures. As a result, a number of central banks-including the Danmarks Nationalbank (DNB), European Central Bank (ECB), Swiss National Bank (SNB), Swedish Riksbank, Bank of Japan (BoJ), and Central Bank of Hungary (MNB) — have pushed key policy rates (mainly the deposit rate on excess commercial bank reserves) into negative territory over the past few years (Figure 2). At present, countries with negative interest rate policies (NIRP) account for one-fourth of world GDP. In conjunction with the implementation of NIRP, yields on a sizable class of sovereign bonds in some of these countries have fallen further below zero.

Historically, negative interest rates-policy-determined or otherwise-have been an extremely rare phenomenon. In the United States, some Treasury bill yields briefly fell below zero during the Great Depression and during the height of the 2008-09 global financial crisis. ${ }^{2}$ The SNB sporadically introduced negative interest rates on foreign deposits during the 1970s in order to prevent capital inflows and excessive appreciation of Swiss franc (Meggyesi 2010). Yields on some Japanese government bonds were negative for a brief period during the downturn of the late 1990s. Swedish Riksbank temporarily lowered its deposit rate below zero in 2009. However, the widespread emergence of negative interest rates outside of a financial crisis is unprecedented.

\footnotetext{
${ }^{1}$ Bernanke (2013) and Blinder (2013) consider the evolutions of monetary policies after the crisis. Lo (2012) reviews a number of major books on the global financial crisis. Kose and Terrones (2015) briefly examine the evolutions of monetary and fiscal policies implemented after the 2007-09 global financial crisis and compare these policies with those during the previous global recession episodes.

${ }^{2}$ Based on closing levels, U.S. 1-month and 3-month T-bill rates fell below zero between early December and midDecember of 2008. During the 1930s, some U.S. government securities appeared to have sporadically returned slightly negative nominal yields (Cecchetti 1988).
} 
Figure 1. GDP, unemployment, and inflation

\section{A. GDP in major advanced economies} Index, 2007Q1=100

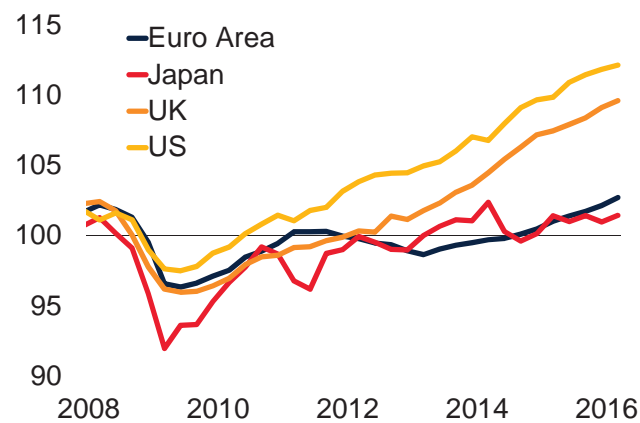

C. Unemployment rate in NIRP economies Percent - Latest -2008Q2 ^ Post-crisis peak 16

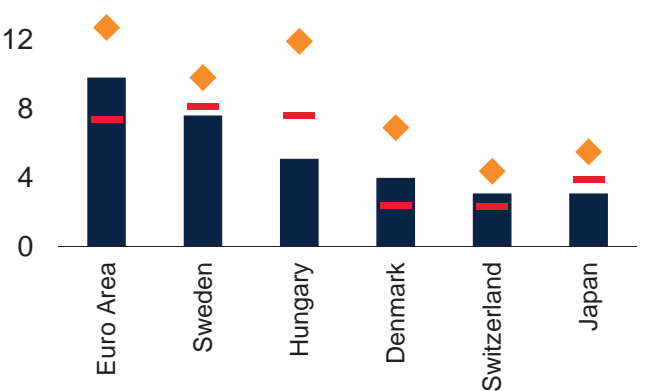

E. 2016 inflation forecasts for NIRP economies

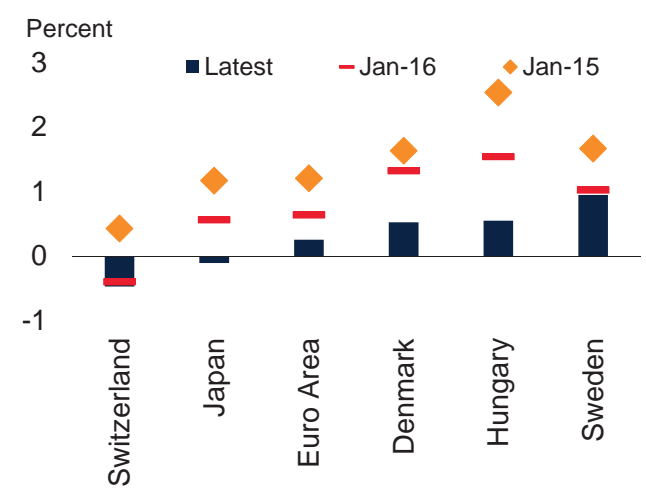

B. Inflation in major advanced economies

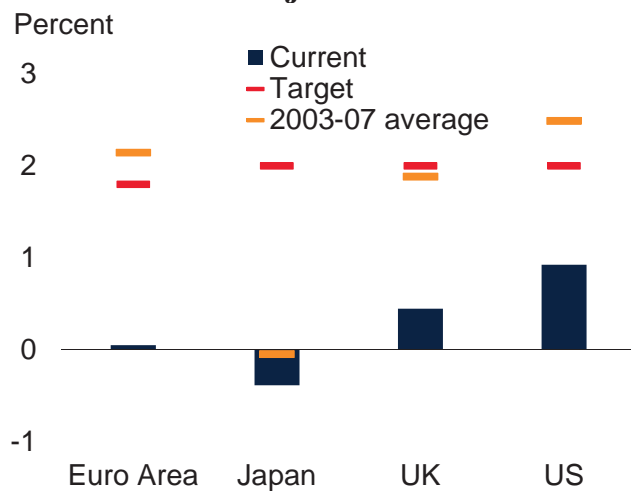

D. 2016 growth forecasts for NIRP economies Percent

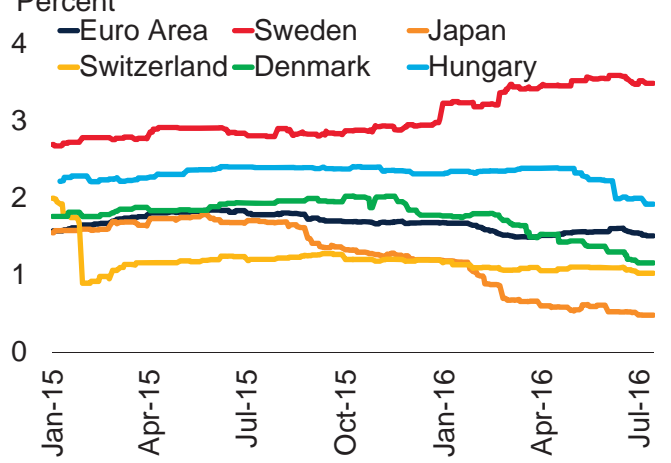

F. 2020 inflation forecasts for NIRP economies

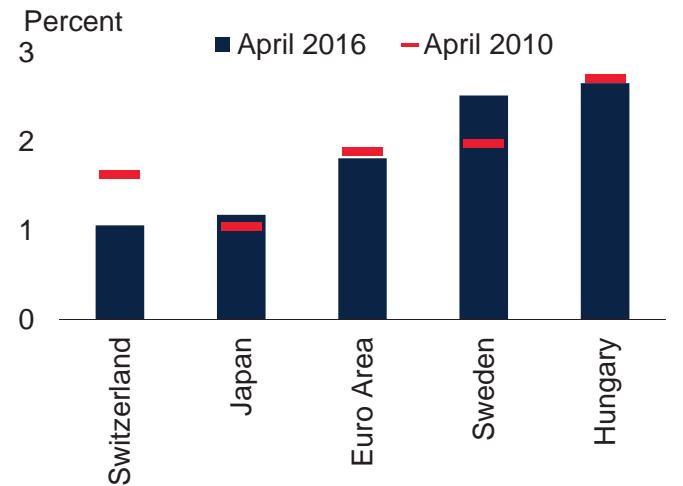

Sources: Haver Analytics, Bloomberg, Consensus Economics, World Bank.

A. Last observation is 2016Q1.

B. Inflation measured as year-on-year changes in the price index for personal consumption expenditures for the United States and headline consumer price indexes for others. Last observation is June 2016.

C. Peak is 2013Q1 for euro area, 2009Q2 for Sweden, 2012Q1 for Hungary, 2010Q1for Denmark, 2009Q4 for Switzerland, and 2009Q3 for Japan. Last observation is June 2016.

D. Consensus Economics growth forecasts for 2016 over time. Last observation is June 2016.

E. Consensus Economics inflation forecasts for 2016 over time. Last observation is June 2016.

F. Consensus Economics inflation forecasts for 2020. 
Figure 2. Policy interest rates and size of economies with negative rates

\section{A. Policy interest rates}

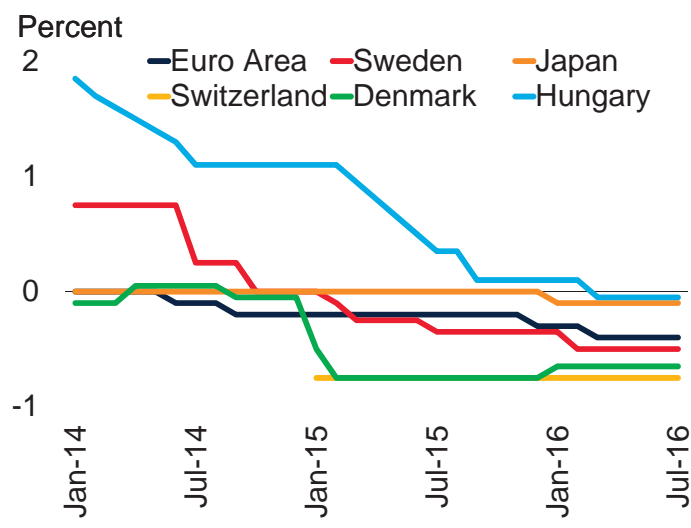

\section{B. Size of economies with negative interest rates}

Percent of world GDP

$30 \quad$ - Policy rate $\quad 5$ year $\backsim 10$ year

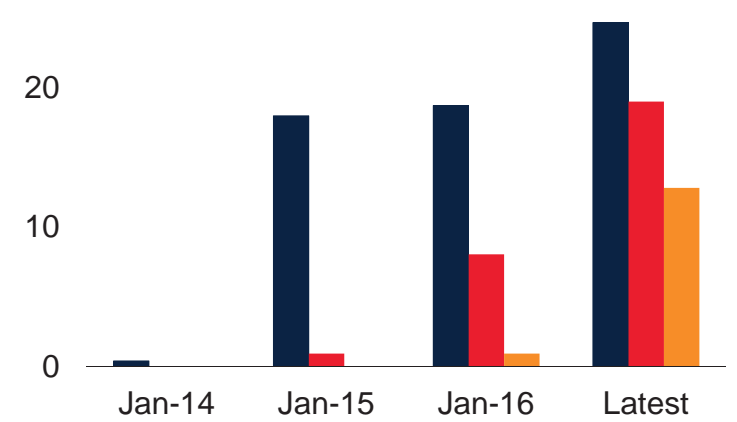

Sources: European Central Bank, Bank of Japan, Swedish Riksbank, Swiss National Bank, Danmarks Nationalbank, Central Bank of Hungary, Haver Analytics, Bloomberg, World Bank.

A: Policy rates are the following: euro area, overnight deposit facility; Sweden, repo rate; Japan, current account deposit; Switzerland, middle point of target range for three-month LIBOR; Denmark, one week certificate of deposit; Hungary, overnight deposit. Last observation is June 2016.

B: Share of world real GDP (in 2010 US\$) accounted for by economies with negative policy rates, 5- and 10- year government bond yields. Monthly averages. Last observation is June 2016.

A cut in policy rates slightly below zero should in principle have similar effects as a cut in rates to low but positive territory. However, policy rates substantially below zero for a protracted period of time could lead to greater risks of financial market disruptions. NIRP, like other unconventional monetary policy measures, could also have spillover effects to emerging market and developing economies (EMDEs), as search for yields in reaction to negative rates in advanced economies may affect capital flows to EMDEs. However, deteriorating macroeconomic fundamentals in EMDEs could limit potential gains from exceptionally favorable financing conditions in NIRP countries, while balance sheet pressures stemming from a strengthening U.S. dollar could heighten policy challenges.

The introduction of NIRP has led to an intensive debate, as illustrated by the quotations at the beginning of this paper. Some argue that NIRP have so far served the intended purpose, complementing the broader set of expansionary measures employed by central banks. Others, however, emphasize financial stability risks associated with NIRP and claim that they may have weakened banks' willingness to lend, contributed to financial market distortions, further inflated asset prices, and delayed the implementation of necessary macroeconomic and structural policies.

Despite these highly polarized discussions, research on NIRP has been quite limited. ${ }^{3}$ This paper aims to shed light on the issue by presenting a comprehensive analysis of the sources and the short-

\footnotetext{
${ }^{3}$ This study builds on an earlier essay we produced on the implications of NIRP employed by some European central banks (World Bank 2015a). Hannoun (2015), Jackson (2015), Cœuré (2016), Citi (2016a), Deutsche Bank (2016a), Hamilton (2016), Morgan Stanley (2016a), Vinals, Gray and Eckhold (2016) and Wessel and Olson (2016) present
} 
term domestic and international implications of NIRP. Specifically, it addresses the following questions:

- Why are some monetary policy rates negative?

- How do transmission channels of monetary policy operate under NIRP?

- How have key financial variables evolved since the introduction of NIRP?

- How could NIRP affect financial stability?

- What are the implications of NIRP for EMDEs?

The rest of the paper is organized as follows. Section 2 presents the context and motivation for implementing NIRP. Section 3 briefly examines the major transmission channels of monetary policy under NIRP. Section 4 analyzes changes in key financial variables after the introduction of NIRP. Following the recent literature on the effects of quantitative easing (QE) policy announcements, this section also uses an event study to assess the initial domestic market reactions to NIRP announcements. ${ }^{4}$ Section 5 explores financial stability implications. Section 6 examines spillovers from NIRP to EMDEs and policy responses to mitigate possible adverse effects. Section 7 concludes.

\section{Why are some monetary policy rates negative?}

Monetary policy across advanced economies has had to deal, since the global financial crisis, with weak demand and below-target inflation. Globally, a lack of investment combined with abundant savings and a diminishing pool of highly-rated low-risk fixed income assets have been associated with a secular decline in the equilibrium real rate of interest (Summers 2014; Rachel and Smith 2015; Bean et al. 2015). ${ }^{5}$ These circumstances help explain why, in a context of continued growth disappointments and rising deflation risks, and with limited support from fiscal and structural policies, a number of central banks have decided, in addition to previous unconventional monetary policy measures, to cut policy rates to negative levels and thus provide additional accommodation. The central banks implementing NIRP are now charging (instead of paying) commercial banks for their excess reserves, effectively taxing banks for hoarding cash.

Commercial banks hold deposits at their central bank for two main reasons: to settle interbank transactions and to meet legal minimum reserve requirements. In return for commercial banks' excess reserves (i.e., reserves above the required minimum level), central banks may pay interest,

brief reviews of various aspects of NIRP. IMF (2016a) analyzes the implications of NIRP in the euro area. Bech and Malkhozov (2016) examine operational aspects of NIRP.

${ }^{4}$ An empirical investigation of broader macroeconomic effects of NIRP would require longer time series to conduct counterfactual analysis and disentangle the role of different factors and policies.

${ }^{5}$ Although estimates vary and are subject to significant measurement uncertainty, real equilibrium rates have been estimated to be only marginally above zero in the United States and slightly negative in the euro area at present (Holston, Laubach and Williams 2016). Given the ECB's inflation target of close but below 2 percent, the neutral nominal rate of interest could currently be as low as $1 \frac{1}{2}$ percent in the euro area, implying that policy rates of zero might not deliver strong enough stimulus in the face of persistent economic headwinds. 
Figure 3. Excess reserves and foreign currency reserves
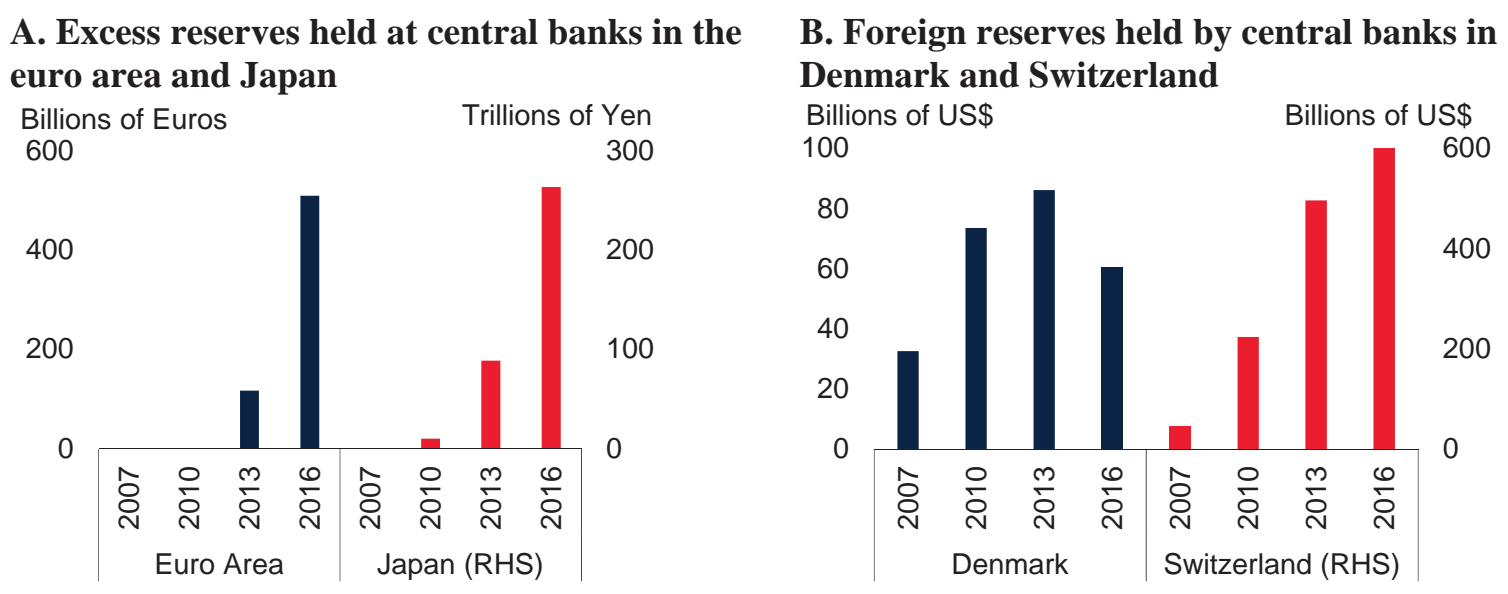

Sources: European Central Bank, Bank of Japan, Danmarks Nationalbank, Swiss National Bank.

A. Excess reserves are the difference between total reserve balances and minimum reserves held by banks. Last observation is June 2016.

B. Foreign reserves are foreign currency assets held by central banks. Last observation is May 2016 for Switzerland, and April 2016 for Denmark.

or a "deposit rate." During normal times, banks minimize such excess reserves, as deposit policy rates are typically below money market rates. However, since the global financial crisis, a wide range of factors, including persistent macroeconomic and financial uncertainty, and bank balance sheet repair, have encouraged commercial banks to maintain higher-than-usual balances in central bank deposit facilities in some advanced economies (Figure 3).

The reasons highlighted by central banks in their decisions to implement NIRP have varied somewhat. The main motivation stated by the ECB, BoJ, Riksbank, and MNB was the need to stabilize inflation expectations, and support growth. In the case of the SNB and DNB, a proximate motivation was the need to respond to currency appreciation and capital inflow pressures. In some cases, NIRP have been accompanied by complementary policy measures to ease financing conditions and stimulate activity while mitigating adverse effects on bank earnings (Table 1). ${ }^{6}$ This section first presents evidence on the aforementioned motives behind the use of NIRP, then briefly discusses why NIRP were employed to respond to the perceived limits of previous policy measures.

\footnotetext{
${ }^{6}$ The Riksbank's deposit rate fell below zero in 2009 for the first time. However, its main policy rate for monetary transmission is weekly repo rate at which banks can borrow or deposit for a period of one week. Danmarks Nationalbank's deposit rate fell slightly below zero (-0.2) in July 2012 for the first time, and returned to positive territory in April 2014. It remained positive until September 2014, and went below zero again after that. In figures presenting monetary policy rates, the reference period starts with the date at which weekly repo rate went below zero for Sweden, and the second period (starting with September 2014) for Denmark.
} 
Table 1. NIRP announcements and complementary policies

\begin{tabular}{|c|c|c|c|}
\hline Central Bank (policy rate) & Date & Rate & Complementary Policies Announced \\
\hline \multicolumn{4}{|l|}{ European Central Bank } \\
\hline \multirow[t]{4}{*}{ (Overnight deposit facility rate) } & June-2014 & -0.10 & $\begin{array}{l}\text { Targeted Longer-Term Refinancing Operations program with 2- } \\
\text { year maturity. Announced preparations for an Asset Backed } \\
\text { Securities Purchase Program }\end{array}$ \\
\hline & September-2014 & -0.20 & Asset Backed Securities Purchase Program initiated \\
\hline & December-2015 & -0.30 & $\begin{array}{l}\text { 6-month extension of asset purchase programs. Expanded pool } \\
\text { of available assets for purchase, no increase in monthly amount }\end{array}$ \\
\hline & March-2016 & -0.40 & $\begin{array}{l}\text { Expanded size of Quantitative Easing program from €60 billion to } \\
€ 80 \text { billion per month until March 2017, added non-financial } \\
\text { corporate bonds to list of assets elibible for purchase, new } \\
\text { Targeted Longer-term Refinance Operations program with four } \\
\text { year maturity }\end{array}$ \\
\hline \multicolumn{4}{|l|}{ Riksbank } \\
\hline \multirow[t]{4}{*}{ (One week repo rate) } & February-2015 & -0.10 & Forward guidance, SEK 10 billion of government bond purchases \\
\hline & March-2015 & -0.25 & Expanded bond purchases to SEK 30 billion \\
\hline & July-2015 & -0.35 & Expanded bond purchases to SEK 75 billion \\
\hline & February-2016 & -0.50 & Reinvested maturing bonds and coupons from QE program \\
\hline \multicolumn{4}{|l|}{ Danmarks Nationalbank } \\
\hline \multirow[t]{6}{*}{ (One week certificate of deposit rate) } & July-2012 & -0.20 & \\
\hline & September-2014 & -0.05 & \\
\hline & January-2015 & -0.20 & \\
\hline & January-2015 & -0.35 & \\
\hline & January-2015 & -0.50 & Suspension of new bond issuance \\
\hline & February-2015 & -0.75 & \\
\hline \multicolumn{4}{|l|}{ Swiss National Bank } \\
\hline \multirow[t]{2}{*}{ (Overnight sight deposit rate) } & December-2014 & -0.25 & Minimum exchange rate reaffirmed \\
\hline & January-2015 & -0.75 & $\begin{array}{l}\text { Franc floor abandoned as overall "overvaluation has decreased," } \\
\text { if necessary promises currency intervention in the future }\end{array}$ \\
\hline \multicolumn{4}{|l|}{ Bank of Japan } \\
\hline (Current account deposit rate) & January-2016 & -0.10 & $\begin{array}{l}\text { No changes to existing Qualitative and Quantitative Easing } \\
\text { program }\end{array}$ \\
\hline \multicolumn{4}{|l|}{ Central Bank of Hungary } \\
\hline (Overnight deposit rate) & March-2016 & -0.05 & \\
\hline
\end{tabular}

Sources: European Central Bank, Riksbank, Danmarks Nationalbank, Swiss National Bank, Bank of Japan, and Central Bank of Hungary.

Notes: "Rate" refers to the main deposit policy rate in most cases, and the main refinancing rate for the Riksbank. Euro area, Denmark, and Switzerland have exemption thresholds and Japan has a three-tier system for negative policy rates. Danmarks Nationalbank also employed currency interventions to maintain the Danish krone's peg against the euro. 


\subsection{Growth and inflation risks}

Reflecting persistent downside risks to growth and declining inflation expectations, the ECB first introduced a negative interest rate applied on its deposit facility in June 2014 and undertook additional cuts through March 2016. For similar reasons, in July 2014, the Riksbank also cut its deposit rate below zero, and became in February 2015 the first (and still to date the only) central bank to bring its main refinancing rate to negative territory. Amid weak growth and inflation prospects, the BoJ and MNB have been the most recent central banks introducing NIRP-in January and March 2016, respectively.

Official statements from these four central banks clearly express the main motivations of the use of NIRP: to provide further accommodation in order to support growth and stabilize inflation in line with their main policy objectives. For example, in a March 2016 press release, the ECB communicated that its main motivation for continued rate cuts deep into negative territory was "to further ease financing conditions, stimulate new credit provision and thereby reinforce the momentum of the euro area's economic recovery and accelerate the return of inflation to levels below, but close to, 2 percent" (ECB 2016a).

As the Riksbank announced the latest rate cut and preserved its bond purchase program in February 2016, it conveyed its main motivation as: "To provide support for inflation so that it rises and stabilizes around 2 percent in 2017, the Executive Board of the Riksbank has therefore decided to cut the repo rate by 0.15 percentage points to -0.50 percent. Purchases of government bonds will continue for the first six months of this year, in accordance with the plan adopted in October" (Riksbank 2016).

The BoJ's decision to implement NIRP in January 2016 was unexpected by many market participants. However, the rationale behind the decision — continued deflation risks amid volatility in global financial markets and slowdown in major emerging markets-was by that point familiar to policy makers. In a January 2016 press release, the BoJ stated: "Policy Board decided to introduce Quantitative and Qualitative Monetary Easing (QQE) with a Negative Interest Rate in order to achieve the price stability target of 2 percent at the earliest possible time" (BoJ 2016a).

Most recently, the MNB referred to "persistently low cost-side inflationary pressure, the slowdown in global growth and the historically low level of inflation expectations" in a March 2016 press release, when it cut its overnight deposit rate to -0.05 percent (MNB 2016).

\subsection{Currency and capital inflow pressures}

For the central banks of Switzerland and Denmark, the reasons for employing NIRP are slightly different. For both countries, spillovers associated with economic and financial conditions in the euro area were a major factor behind pushing policy rates into negative territory.

In Switzerland, to stem capital inflows and maintain the exchange rate cap against the euro in place since 2011, the SNB announced its intention to lower its deposit rate below zero in December 
2014, before abandoning the cap and further slashing its main policy rate in January 2015. Foreign currency reserves, however, continued to accumulate (Figure 3). The SNB stated in March 2016 that "[t]he Swiss franc is still significantly overvalued... [n]egative interest [rate] is making Swiss franc investments less attractive," an indication that the exchange rate is a key input for the SNB's monetary policy decisions (SNB 2016).

The DNB, which maintains its currency within a narrow fluctuation band around the euro, initially set its deposit rate below zero in July 2012, in response to rising capital inflows amid heightened financial stress in the euro area. The deposit rate returned to positive territory in April 2014, but was cut again to negative territory in September 2014, following the ECB's decision to implement negative rates. In a speech in March 2015, DNB Governor Lars Rohde noted: "In order to stem the capital inflow, DNB intervened in the foreign exchange market for very large amounts, and we also reduced our monetary policy interest rates on several occasions. The interest rate on certificates of deposit is now minus 0.75 per cent - a level not seen previously" (Rohde 2015).

\subsection{Perceived limits of previous policy measures}

In addition to downside risks to growth and inflation, and capital inflows and currency considerations mentioned above, the perceived limits of unconventional easing measures encouraged a further extension of the menu of policy options, including the removal of the zero lower bound constraint on policy rates in some economies. There are at least three major reasons why these central banks introduced NIRP, instead of simply expanding earlier unconventional measures.

Showing resolve to meet policy objectives. As discussed by Williams (2014), two major messages emerge from research on conventional monetary policy in the neighborhood of the zero lower bound. First, policymakers should act aggressively in response to deflation risk; second, monetary policy should remain more expansionary than prescribed by standard policies following an episode during which policy is constrained by the zero lower bound.

However, the perceived zero lower bound for policy rates constrains central banks' ability to commit to additional policy easing if downside risks materialize. The adoption of negative policy rates relaxed this non-negativity constraint, and underlined the resolve of central banks to undertake additional measures to meet their objectives. ${ }^{7}$ NIRP also signaled these central banks' intention to maintain policy rates at low levels for an extended period of time, contributing to a downward shift in the yield curve.

Diminishing pool of assets to purchase. Since the 2007-09 global financial crisis, central banks have implemented a range of unconventional measures, including asset purchase and credit easing

\footnotetext{
${ }^{7}$ IMF (2016a, 2016b) claim that ECB's NIRP signaled a strong commitment to price stability. Kocherlakota (2016a) emphasizes the importance of this issue in the context of the U.S. monetary policy. He argues that if the Federal Reserve convinces market participants its desire and ability to employ NIRP, this could help promote confidence in monetary policy and possibly accelerate the process of policy normalization.
} 
Figure 4. Quantitative easing and central banks' balance sheets

\section{A. Size of asset purchase programs}

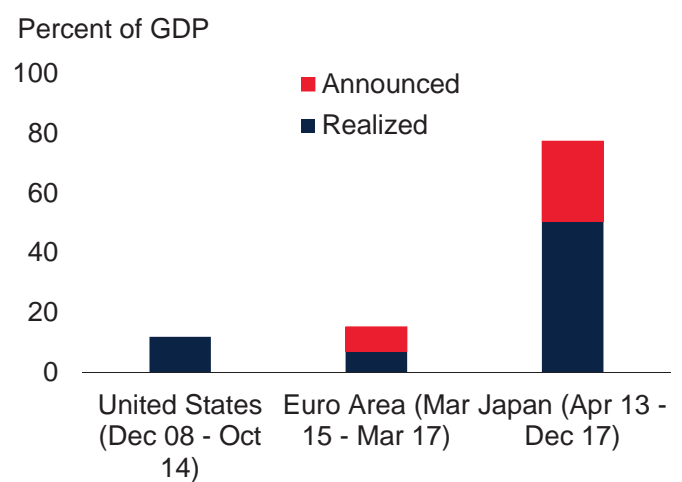

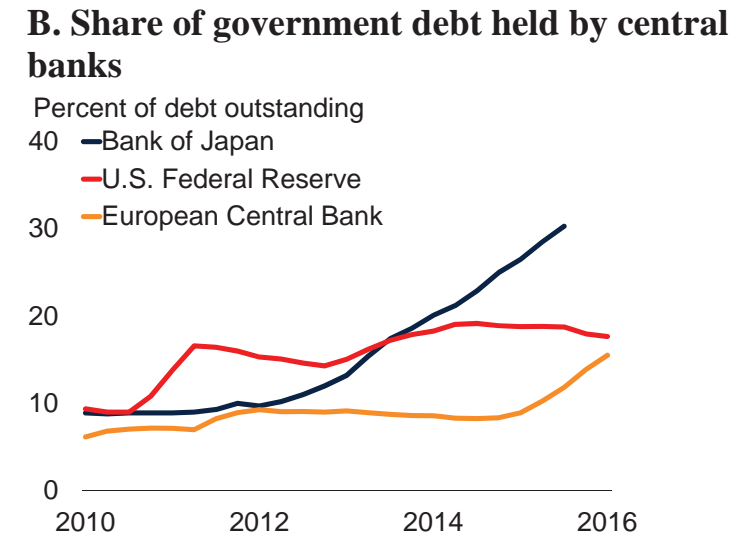

B. Share of government debt held by central banks

Percent of debt outstanding

-European

Sources: J.P. Morgan, Bloomberg, Federal Reserve Bank of St. Louis, Haver Analytics, National central banks, World Bank. A. Net asset purchases since the beginning of quantitative easing programs. Announced estimates based on stated policy intentions as of May 2016. The ECB's QE program is assumed to end in March of 2017 and the Bank of Japan's QQE is assumed to continue until the end of 2017.

B. Last observation is 2016Q1 for the U.S. Federal Reserve and the European Central Bank, and 2015Q4 for the Bank of Japan.

programs, as well as exchange rate interventions. As a result, their balance sheets have expanded rapidly (Figure 4). In some cases, central bank purchases have drawn down the pool of eligible assets. For instance, asset purchases by the ECB, which amount to $€ 80$ billion per month until at least March 2017, mainly comprise sovereign bonds based on a defined allocation key and strict eligibility criteria. Specifically, these criteria prohibit purchases beyond 25 percent of the outstanding amount of individual securities, 33 percent of any given issuer's debt, and of bonds with yields below the ECB's deposit rate, currently set at -40 basis points. Despite a relatively limited fraction of government debt currently held by the ECB, scarcity considerations could intensify given the increasing share of highly rated sovereign bonds trading at yields closer to the lower limit of eligibility. ${ }^{8}$ The risk of mismatch between the effective supply and the intended scale of ECB's government bond purchases encouraged a broadening of eligibility criteria and the implementation of other easing measures, including purchases of corporate sector bonds and NIRP.

In Japan, the size of central bank balance sheet and the share of government debt held by the BoJ increased sharply under its Qualitative and Quantitative Easing (QQE) program, initially launched in April 2013. Under the current program, government bond purchases will cover roughly half of newly issued debt expected for fiscal year 2016 (Japan Ministry of Finance 2016; BoJ 2016b). The BoJ committed to purchase other types of assets, such as exchange-traded funds, real estate investment trusts, and corporate bonds, before deciding to introduce NIRP to signal a further extension of policy easing measures.

\footnotetext{
${ }^{8}$ IMF (2015a) argues that the ECB could preempt the risk of shortage in these bonds by having a more flexible menu of assets to purchase. The ECB started buying corporate bonds in June 2016.
} 
Diminishing returns from $Q E$. Evidence suggests that the effectiveness of $\mathrm{QE}$ might have diminished over time (Krishnamurthy and Vissing-Jorgensen 2011; Bauer and Neely 2014; Glick and Leduc 2012). In general, event studies of earlier QE programs show larger impacts, as the abatement of market stress, forward guidance, and portfolio balance channels combined to generate more significant effects on financing conditions. Event studies of later QE programs indeed report a smaller impact, potentially indicating diminishing returns over time (Table A.1).

\section{How do transmission channels of monetary policy operate under NIRP?}

While the underlying motives for the implementation of NIRP vary across central banks, their transmission channels to activity and inflation are conceptually analogous to those of conventional monetary policy. ${ }^{9}$ Specifically, NIRP are expected to be transmitted mainly through the interest rate, credit, portfolio, and exchange rate channels. However, under NIRP, there are complications associated with these channels that could limit the effectiveness of policy.

Interest rate channel. Similar to rate cuts in positive territory, cutting policy rates slightly below zero should reduce the rates at which financial intermediaries conduct their borrowing and lending activities. In particular, rate cuts in negative territory can be expected to reduce money market rates and bond yields at the short end of the maturity spectrum. ${ }^{10}$ A policy-induced decline in the short-term nominal interest rates should result in lower longer-term nominal interest rates, as investors arbitrage differences in risk-adjusted expected returns across debt securities of different maturities. ${ }^{11}$ NIRP could also further compress long-term yields if charging banks for hoarding cash leads to purchases of longer dated debt securities. These effects could combine to lower real interest rates and borrowing costs, thus encouraging households and firms to increase spending and investment.

However, the interest rate channel of monetary policy transmission faces some constraints under NIRP. For example, regarding commercial deposit and lending rates, banks may hesitate to impose negative rates on individual or corporate depositors to prevent a shift to cash or other financial assets that would reduce their deposit base. This tendency, combined with efforts to maintain interest margins, could potentially reduce the pass-through of NIRP to lending rates. ${ }^{12}$

Credit channel. Monetary policy is expected to affect the amount of credit available to households and firms by changing their external finance premium (balance sheet channel or broad credit channel), and by changing banks' incentive for extending loans (bank lending channel or narrow

\footnotetext{
${ }^{9}$ Mishkin (1995) and Boivin, Kiley and Mishkin (2010) present reviews of monetary policy transmission channels.

${ }^{10}$ DNB Governor Lars Rohde, suggested that the transmission would be similar to positive low interest rates: "Apart from certain technical difficulties, negative interest rates are, basically, not so different for the financial sector to handle than persistent low interest rates" (Rohde 2015).

${ }^{11}$ The degree to which changes in policy interest rates can affect the long-rates depends, among others, on the monetary policy regime, the credibility of the central bank, the structure of financial markets, and external factors (Walsh 2010; Duffee 2013).

${ }^{12}$ Waller (2016) argues that NIRP could even have an adverse effect on financing conditions, as banks might increase lending rates or charge higher fees for their activities in order to mitigate any adverse impact of negative rates on their profits.
} 
credit channel). The credit channel facilitates an amplification mechanism (financial accelerator mechanism) alongside the interest rate channel (Bernanke and Gertler 1995; Bernanke, Gertler, and Gilchrist 1999). NIRP effectively amounts to a tax on liquidity hoarding by banks, which should encourage them to use excess reserves to increase lending. However, there could be an adverse impact on credit growth if banks charge higher lending rates to cover their likely losses associated with negative interest rates or if lower profitability and diminished capital base make them more reluctant to lend. ${ }^{13}$

Portfolio channel. A policy-induced decline in short-term interest rates should support the demand for higher-yielding assets, such as equities. Higher asset prices in turn can induce wealth effects, and through higher valuations support investment and eventually growth. The positive effect could be reinforced by expectations of stronger growth associated with additional monetary policy easing. The transmission mechanism under NIRP should be broadly similar, but NIRP (as other unconventional monetary policies), could potentially distort asset valuations and lead to risks of asset price bubbles, if sustained over a prolonged period of time.

Exchange rate channel. In open economies, additional effects of a policy-induced decline in short-term interest rates come through currency adjustments. When domestic interest rates decline relative to foreign rates, the domestic currency is expected to depreciate to equalize risk-adjusted real returns on various debt instruments. Hence, rising interest rate differentials associated with NIRP can be expected to contribute to domestic currency depreciation, discourage capital inflows, and promote net exports. However, if many countries simultaneously undertake NIRP to promote exports, these could lead to beggar-thy-neighbor policies of competitive devaluations.

\section{How have key financial variables evolved since the introduction of NIRP?}

In light of the above transmission channels and expected movements in key domestic financial variables, this section first explores the evolution of money market, deposit, and lending interest rates, bond yields, and currencies after the introduction of NIRP. It then presents two event studies focusing on changes in key financial variables following NIRP announcements and comparison of these changes with those of previous monetary policy announcements.

\subsection{Evolution of money market, deposit, and lending rates}

As suggested by the interest rate channel, policy rate cuts are usually reflected in analogous declines in money market rates. Consistent with expectations of a similar effect to those of conventional monetary policy transmission, the overnight, 1-month, and 3-month money market

\footnotetext{
${ }^{13}$ While the opportunity cost of holding cash could set a physical limit to negative interest rates, the point when further rate cuts in negative territory cease to provide stimulus to the economy might impose an equally binding constraint on NIRP for central banks (Cœuré 2016). Brunnermeier and Koby (2016) refer to this rate as the "reversal rate", which could depend on market structure, prudential regulation and other policy initiatives, including QE.
} 
rates have declined below zero following NIRP announcements in all economies (except in Hungary, where the MNB reduced its deposit rate to just negative 5 basis points) (Figure 5). Declining wholesale rates have allowed large corporations with direct access to commercial paper and corporate bond markets to reduce their short-term funding costs, while negative money market rates have encouraged investors to switch to riskier and longer duration assets.

The fall in bank wholesale funding costs has been reflected in lower lending rates, but downward rigidities to retail deposit rates might have contributed to reduced pass-through in some cases (Figure 6). Movements in deposit rates have varied across countries but there is evidence that banks have generally proved reluctant to pass on negative rates to retail depositors, as these remain a key source of financing. In the euro area and Sweden, deposit rates moved to about zero, remaining slightly positive in the euro area. ${ }^{14}$ However, some rates on corporate deposits have gone below zero in Denmark and Switzerland. ${ }^{15}$

Banks that rely more on retail deposits for funding are less able to reduce lending rates to corporations and households and have in some cases increased fees to compensate for lower margins. In most cases, however, lending rates declined under NIRP, particularly in countries with greater competition among banks and a higher proportion of variable rates and shorter lending maturities (IMF 2016a). The decline in short-term lending rates in the euro area has exceeded that of policy and wholesale funding rates. Since other policy initiatives were undertaken over the same period, including additional QE measures, the specific impact of NIRP on lending rates is difficult to isolate. In Denmark and Sweden, lending rates generally declined following NIRP announcements, albeit sluggishly (Viñals, Gray and Eckhold 2016).

The link between policy rates and longer term lending rates, such as residential mortgages, can be complex. For instance, SNB (2015) notes that Swiss banks initially increased mortgage rates following the policy rate cut to -0.75 percent, to counter pressure on interest margins, as the cost

\footnotetext{
${ }^{14}$ This observation is consistent with ECB's views, as noted by Draghi (2016): "We also saw no significant evidence that these negative rates had been passed through to the depositors or to the borrowers from the banking system." IMF (2015b) also reports that the deposit rates remained positive in Sweden, except for those of large corporations. ${ }^{15}$ SNB (2015) states that banks reacted to the decline in money market rates following the NIRP decision by applying negative interest rates or higher fees on large corporate and institutional deposits. DNB (2015b, 2015c) reports that developments within the NIRP territory were not unusual: mortgage rates declined, and negative rates were passed to some degree onto depositors except households. Huttl (2014) reports minor changes, if any, in retail interest rates during DNB's earlier experience in negative territory between July 2012 and April 2014. He argues that banks might have hesitated to pass through loan rates due to profitability concerns. Also, the level of policy rate was relatively higher in that period compared with more recent levels (-20 basis points in the earlier period versus -75 basis points more recently). Tong (2016) examines the drivers of bank deposit rates under NIRP in Japan. He reports that the variation in banks' responses to NIRP likely reflect their ability to rebalance portfolios, to avoid negative policy rates on their excess reserves, and to maintain their funding costs.
} 
Figure 5. Policy and money market rates

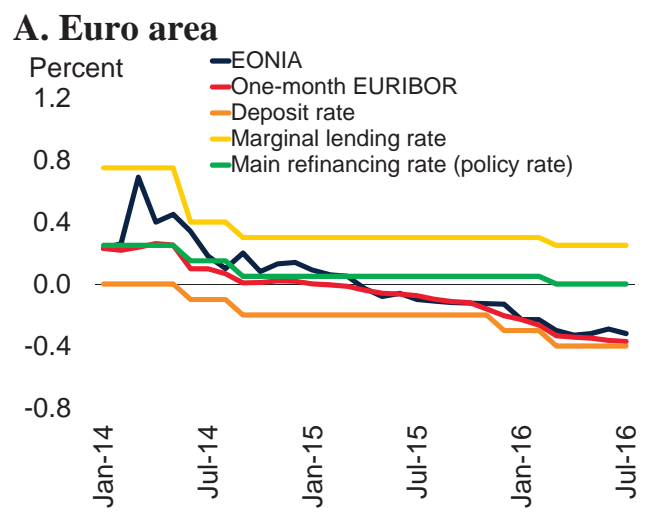

\section{Switzerland}

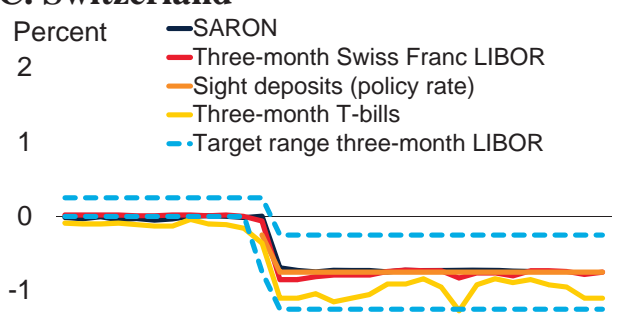

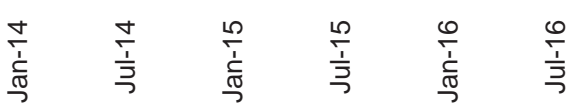

\section{E. Japan}

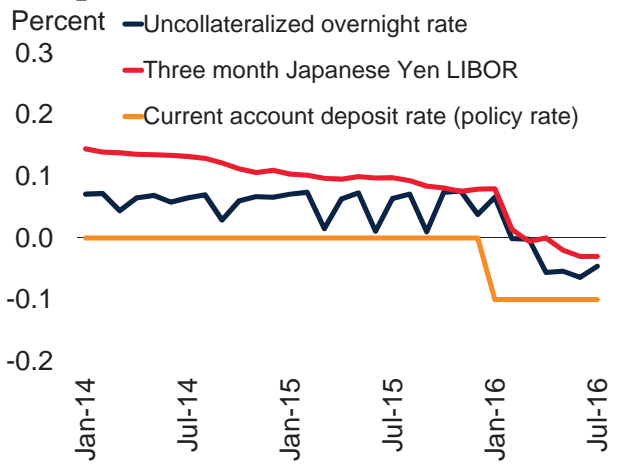

\section{B. Sweden}

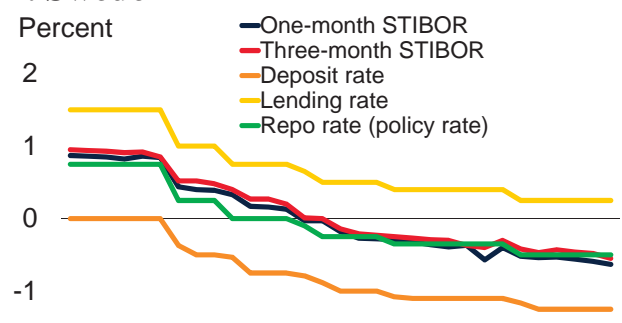

$-2$

\begin{tabular}{|c|c|c|c|c|}
\hline 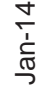 & $\frac{\stackrel{\Delta}{1}}{\frac{1}{5}}$ & 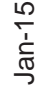 & $\frac{\stackrel{2}{7}}{\frac{1}{5}}$ & $\begin{array}{l}\stackrel{0}{1} \\
\stackrel{1}{\sigma} \\
\stackrel{\sigma}{n}\end{array}$ \\
\hline
\end{tabular}

\section{Denmark}

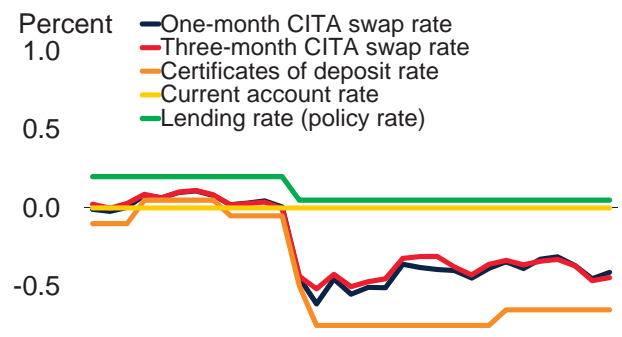

$-1.0$

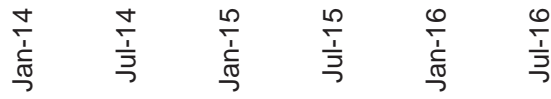

\section{F. Hungary}

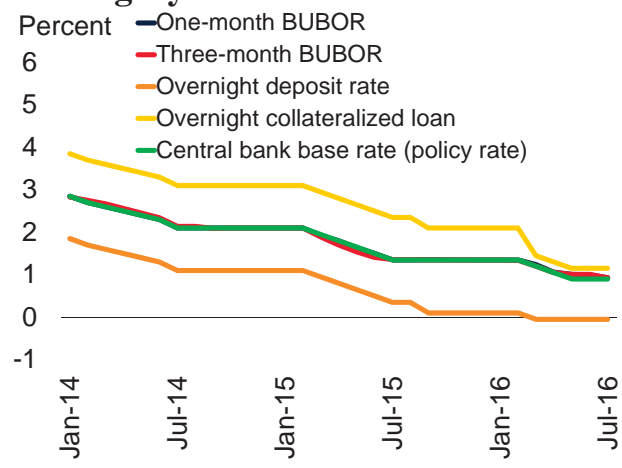

Sources: European Central Bank, Riksbank, Danmarks Nationalbank, Swiss National Bank, Bank of Japan, Central Bank of Hungary, Haver Analytics, Bloomberg, World Bank, Trading Economics.

Notes: Last observation is July 2016.

A. EONIA: Euro Over Night Index Average. Euribor: Euro Interbank Offered Rate.

B. STIBOR: Stockholm Interbank Offered Rate.

C. SARON: Swiss Average Rate Overnight.

D. CITA: Copenhagen Interbank Tomorrow/Next Average.

E. LIBOR: London Interbank Offered Rate.

F. BUBOR: Budapest Inter-Bank Offer Rate. 
Figure 6. Deposit and lending rates

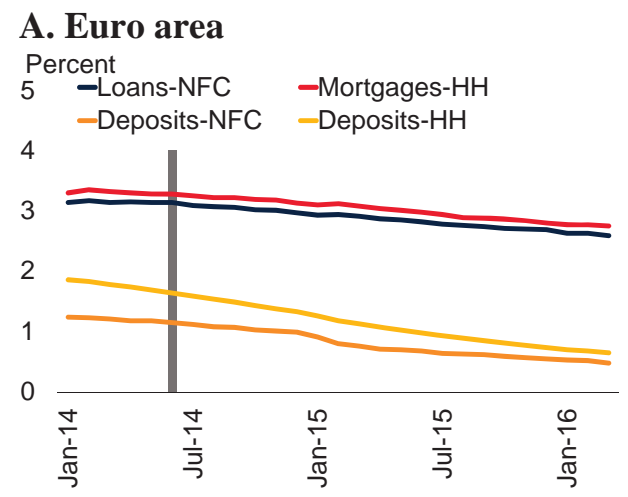

C. Switzerland

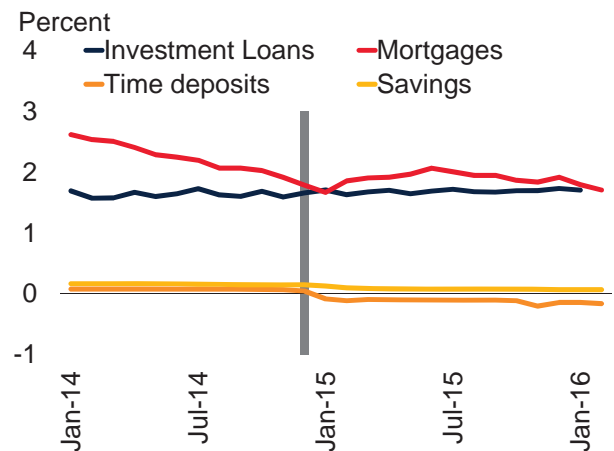

E. Japan

Percent

$1.2 \quad$-Loans -Deposits

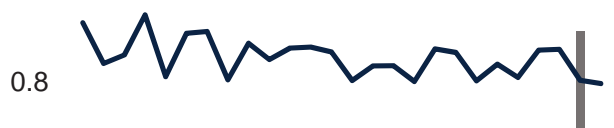

0.4

0.0

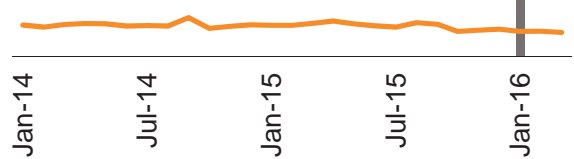

B. Sweden

Percent

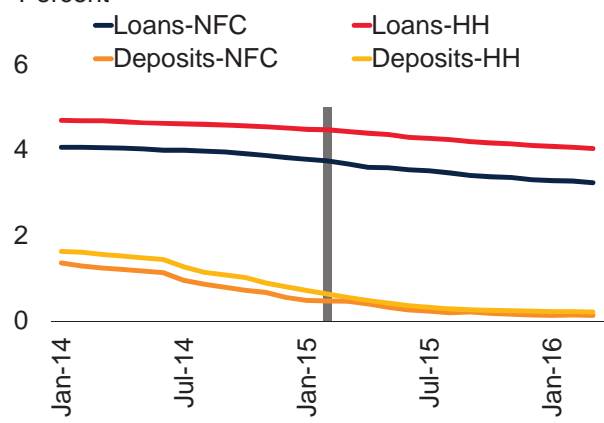

D. Denmark

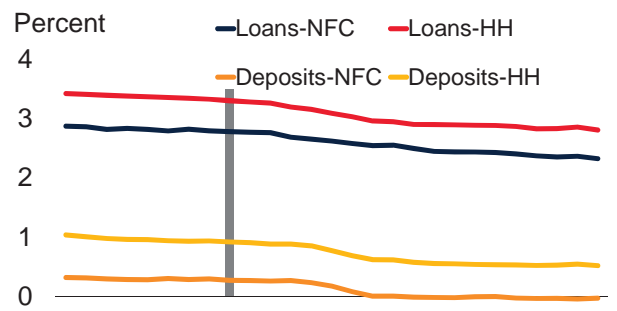

$-1$

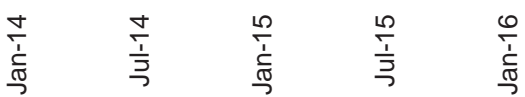

F. Hungary

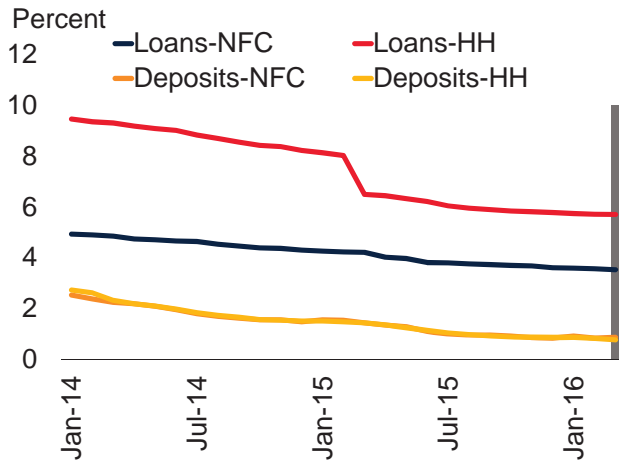

Sources: European Central Bank, Swiss National Bank, Danmarks Nationalbank, Bank of Japan, World Bank.

Notes: Last observation is March 2016 and rates are annualized unless otherwise reported. The vertical lines refer to the date at which corresponding central bank started implementing NIRP.

A. B. F. Loan and mortgage rates are for lending with maturity over 5 years. Deposits are with agreed maturity up to two years. "HH" stands for "Households and non-profit institutions serving households". "NFC" stands for "Non-financial corporations". Rates for domestic outstanding amount in local currency.

C. Investment loans are with fixed interest rate. Mortgages are with fixed interest rates and 10 years of maturity. Time deposits are at least CHF100,000 and maturity in 12 months. Reported rates are on domestic new business amount in local currency. All series represent median values across banks. Last observation is February 2016 for Investment Loans and March 2016 for the rest.

D. "HH" stands for "Households and non-profit institutions serving households". "NFC" stands for "Nonfinancial corporations". Rates for domestic outstanding amount in local currency.

E. Deposits represent average interest rates on new time deposits. Loans represent average contracted interest rate on new loans and discounts with domestically licensed banks. The last observation of loans is February 2016.

Rates on domestic new business in local currency. 
of term hedging rose during a period of uncertainty in financial markets. In 2016, markets adapted to the negative policy rate environment, and Swiss mortgage rates fell again, albeit marginally in view of the significant drop in policy rates. A low pass-through may, among other factors, reflect the greater reliance of Swiss banks on retail deposits (BIS 2013).

\subsection{Evolution of sovereign bond yields and inflation}

Consistent with the above transmission channels, NIRP has generally been associated with a downward shift in the yield curve. Government bond yields on short maturities have turned increasingly negative (Figure 7). In the economies where NIRP have been implemented, around 40 percent of sovereign bonds with maturities between one and three years were trading at negative yields in June 2016. The fraction of negative yielding bonds is the highest in Switzerland, followed by Japan and Germany. Both Germany and Japan issued 10 year sovereign bonds yielding negative returns in 2016, while, in Switzerland, sovereign debt of up to 50 years maturity briefly traded at negative yields in mid-2016. The impact of NIRP on bond yields appears to reflect primarily a downward shift in expectations about the future path of policy rates, rather than a further compression of term premia from already low levels. This is consistent with the stated goals of NIRP and highlights its complementarity with QE policies targeting more specifically a compression of term premia and portfolio balance effects.

Besides the effect of NIRP, there are other factors driving negative yields, particularly those beyond the short end of the yield curve. These include global forces, such as declining inflation and growth expectations, low investment and excess savings, as well as a diminishing pool of highly-rated low-risk fixed income assets, which have put significant downward pressure on global real interest rates. ${ }^{16}$ Large scale asset purchase programs by major central banks, safe haven flows during financial stress episodes, and deteriorating creditworthiness have further drained the pool of safe assets in the post-crisis period, driving long-term yields down (Caballero and Farhi 2014).

Since the introduction of NIRP, both inflation projections and expectations have continued to decline. The downgrades in inflation projections over the policy relevant horizon (two years) reflected to a large extent the impact of sharply declining oil and other commodity prices since mid-2014. However, long term inflation expectations have also showed signs of a downward drift. $^{17}$

\footnotetext{
${ }^{16}$ Bernanke (2005), for instance, argues that a major reason for globally low interest rates has been the global excess of saving over investment. Caballero et al. (2008) find that asset market collapses in Asian economies during 1990s may have led to a shortage in the supply of low-risk assets and stimulated capital flows to the United States, driving real interest rates down. For the literature on factors that led to the emergence of negative yields, see Summers (2014), Rachel and Smith (2015), Bean et al. (2015), Blanchard, Furceri, and Pescatori (2014).

${ }^{17}$ Inflation compensation derived from forward swap rates are subject to changing liquidity and market conditions, but the persistent decline observed in some NIRP economies and across other major advanced economies since 2014 could also reflect changing views of market participants about the ability of central banks to generate inflation when policy rates are already negative or close to zero (Perez-Segura and Vigfusson 2016; Elliot et al. 2015; Sussman and Zohar 2015).
} 
Figure 7. Bond yields, policy rate expectations and inflation

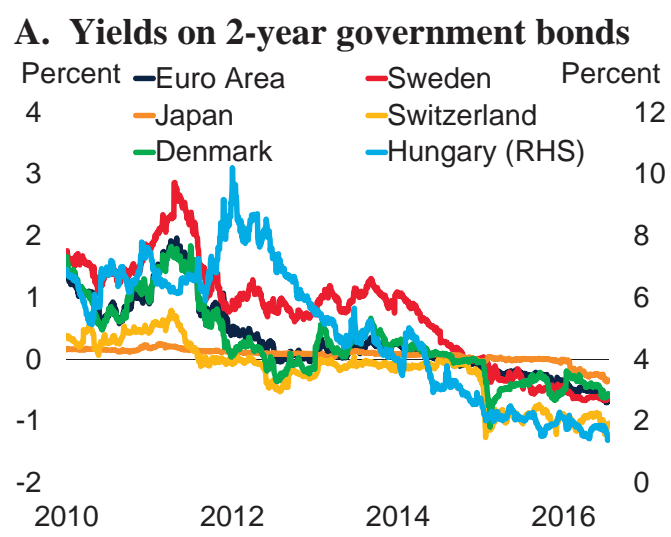

C. Policy interest rate expectations

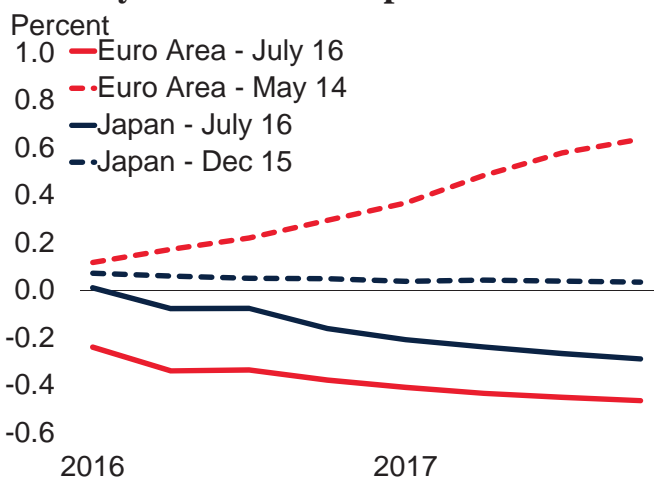

E. 2016 inflation forecasts

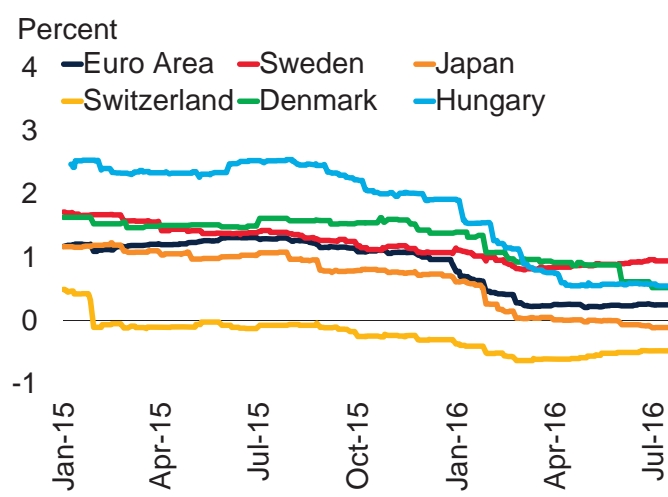

B. Yields on 10-year government bonds

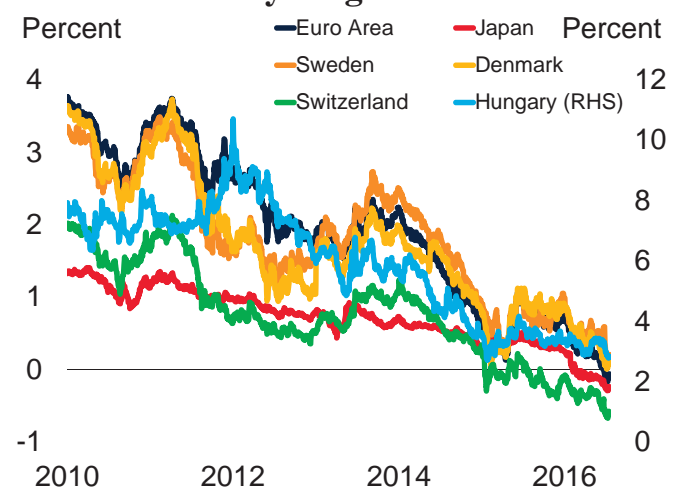

D. Term spreads

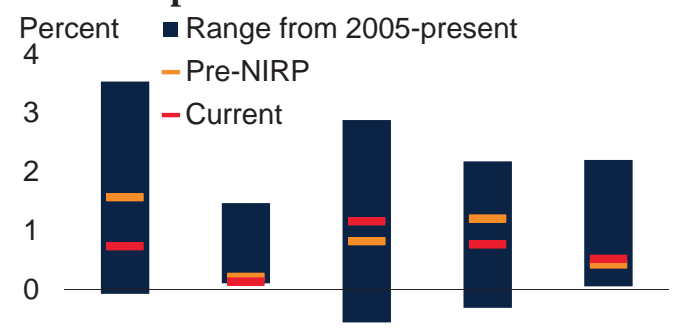

$-1$

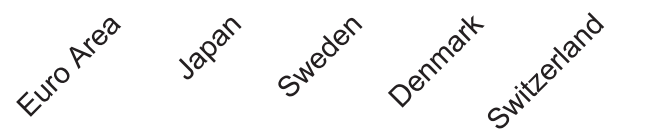

\section{F. Long term market-based inflation} expectations

Percent

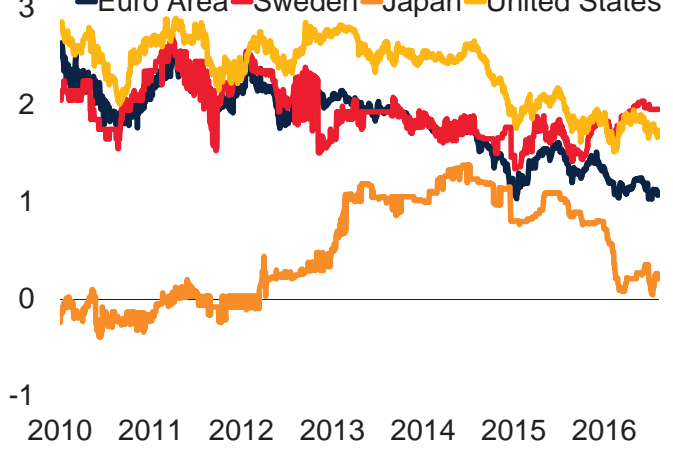

Sources: European Central Bank, Bloomberg, J.P. Morgan, Haver Analytics, World Bank.

A.B. "Euro Area" yield is from the ECB's fitted AAA-rated euro area government bond yield curve which includes all AAA rated euro area sovereigns. Last observation is July 2016.

C. Policy rate expectations derived from interest swap contracts. Last observation is July 2016.

D. Term spreads are the percentage point differences between 10- and 2-year government bond yields. "Pre-NIRP" is the

level on from the day before each country entered into its negative policy rate regime. Last observation is May 2016.

E. Consensus Economics inflation forecasts for 2016 over time. Last observation is June 2016.

F. Inflation expectations derived from 10-year zero coupon swap rates. Last observation is July 2016. 


\subsection{Evolution of exchange rates}

The currencies of NIRP countries have shown varied responses. On average, they have depreciated against the U.S. dollar and to a lesser extent in trade-weighted-terms since the corresponding policy decisions, consistent with the exchange rate channel mentioned earlier. However, the Japanese yen and Swiss franc are notable exceptions to this trend (Figure 8). ${ }^{18}$ In Japan, the appreciation of the yen appeared to be mostly driven by capital inflows due to flight to safety considerations and concerns about deflation risks raising expected real interest rates. ${ }^{19}$ In Switzerland, the rate cut in January 2015 was directly related to the SNB's decision to abandon its exchange rate ceiling vis-à-vis the euro, which led to a sharp appreciation. In place since 2011, the exchange rate policy had become untenable in the face of rapid capital inflows and increasingly accommodative policy in the euro area.

\subsection{Initial reaction in financial markets to NIRP announcements: An event study}

While a visual exploration of the evolution of various financial variables gives a sense of the transmission channels of NIRP, it does not provide evidence on the specific effect of the adoption of NIRP. Isolating the effect of monetary policy announcements and their subsequent impact from complementary policies or other economic developments constitutes a significant empirical challenge. To address this difficulty, a large strand of the literature on the impact of QE policies employs event studies over short periods of time (Gagnon 2016). In this section, an event study is conducted to analyze changes in key financial variables following NIRP announcements.

The "event" is defined as a policy rate cut announcement into (or within) negative territory, for a total a 17 observations for the five major central banks implementing NIRP (four for ECB, four for Riksbank, six for DNB, two for SNB, and one for BoJ). The event study tracks seven variables: 1- and 3-month interbank market rates, 2- and 10-year bond yields, 10-year inflation expectations (swap rates), the nominal effective exchange rate, and equity prices. The study is restricted to a one-day event window around the announcement, as longer windows likely include the effects of other unrelated developments. Events are pooled over time and across countries, and changes in the variable of interest are tracked and averaged within the observation window.

The event study has some important caveats implying that it provides useful but only tentative evidence of the initial impact of NIRP. First, the number of events in the sample is relatively small. Second, additional policy measures (particularly QE measures) were often announced or signaled at the same time as did NIRP. While it is reasonable to assume that NIRP announcements can help explain changes in short-term market interest rates, the changes in longer-term yields, inflation expectations, and equity and currency markets can be difficult to interpret. Third, the measured

\footnotetext{
${ }^{18}$ Vinals, Gray and Eckhold (2016) argue that the impact of NIRP on exchange rates has been mixed across countries. Huttle (2014) studies developments during Denmark's first experience with NIRP, and shows that the Danish krone depreciated during that episode.
} 
Figure 8. Exchange rates, yield differentials and foreign reserves

A. Bilateral exchange rate with U.S. dollar Percent - Change since June 2014

$20-$ Change since first NIRP announcement

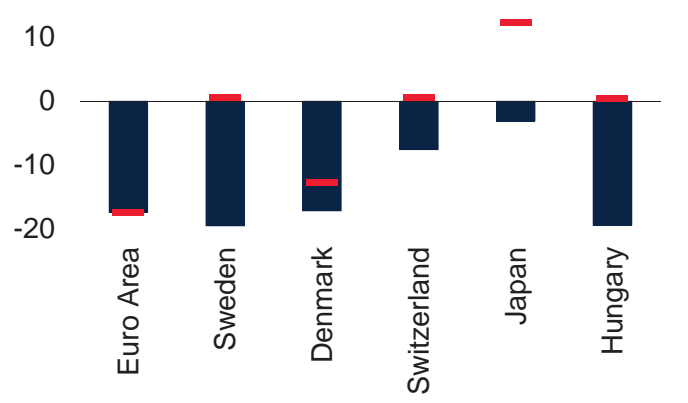

\section{Real effective exchange rate}

Percent Change since June 2014

$10-$ Change since first NIRP announcement

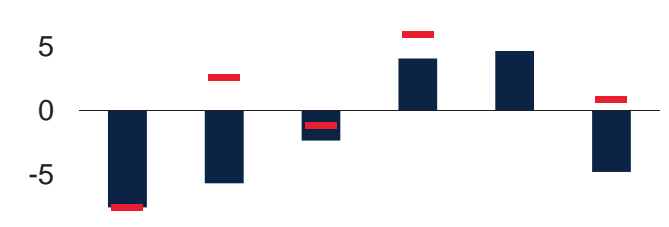

$-10$

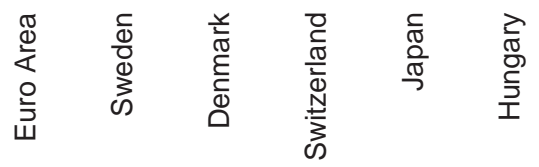

E. Yen and yield differential with U.S. Exchange rate
14

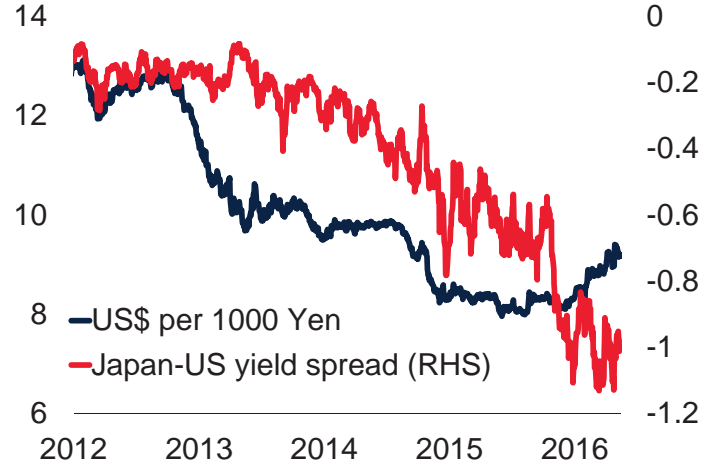

\section{B. Nominal effective exchange rate}
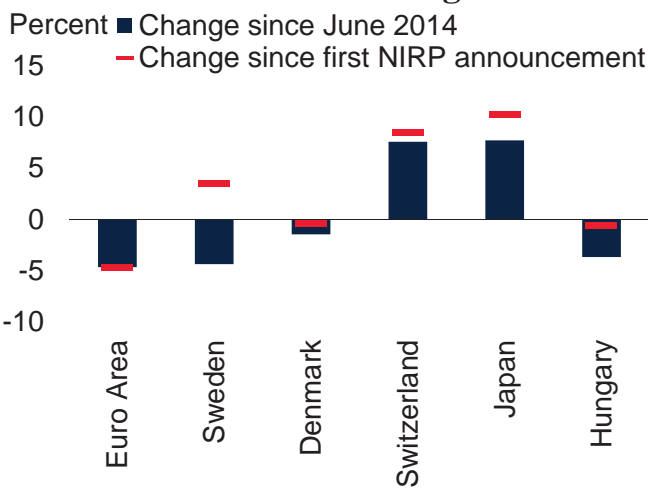

D. Euro and yield differential with U.S.

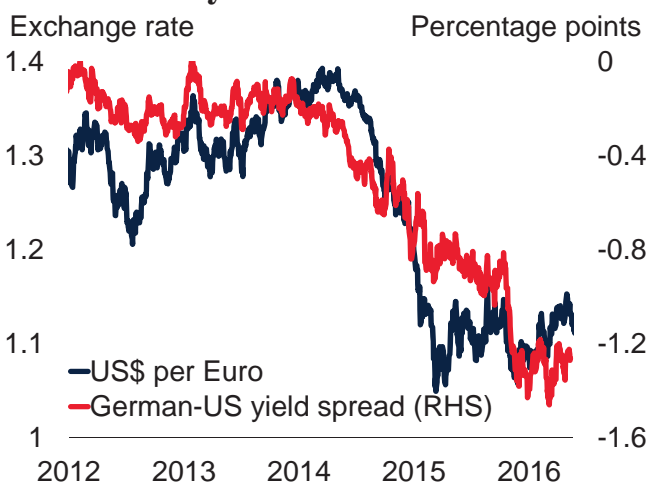

F. Swiss Franc and foreign reserves

Exchange rate Billions of Swiss Francs

1.00 -Euro per Franc 700

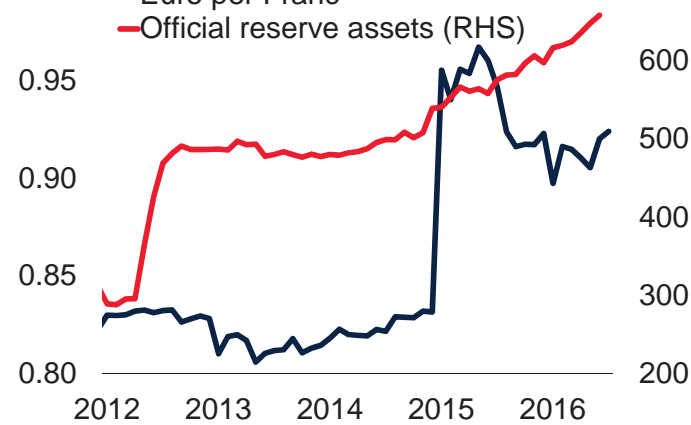

Sources: J.P. Morgan, Bloomberg, Haver Analytics, World Bank.

Notes: A.B.C. A decline in the exchange rate (negative value) indicates a depreciation. NIRP announcements are June 2014 for euro area, February 2015 for Sweden, December 2014 for Switzerland, September 2014 for Denmark, January 2016 for Japan, and March 2016 for Hungary. Last observation is June 2016.

D. German-US yield spread is the percent difference between 2-year government bond yields in Germany and the United States. Last observation is June 2016.

E. Japan-US yield spread is the percent difference between 2-year government bond yields in Japan and the United States.

Last observation is June 2016.

F. Last observation is June 2016. 
change on the announcement day does not account for anticipation effects. Fourth, policy interest rate cuts of different sizes are treated equally.

Following NIRP announcements, money market rates on average declined by 2 to 3 basis points, 2-year sovereign bond yields dropped by close to 6 basis points and 10-year sovereign bond yields by nearly 4 basis points (Figure 9). Inflation expectations hardly moved around policy announcements, while developments in foreign exchange rate markets were mixed, with the sharp appreciation in the Swiss franc in January 2015 having a large influence on the sample average.

If the event window is extended up to one month, qualitatively similar but generally larger results are obtained, even though this longer window is likely to be influenced by factors unrelated to NIRP (Figure A.1). During a 30-day period, the median cumulative drop in 2-year and 10-year government bond yields was more than 15 basis points, reflecting a corresponding shift in policy rate expectations. Although the range of outcomes varies significantly across countries and events, NIRP appear to have been associated with the expected downward shift in the yield curve in most cases. Enduring changes in exchange rates and equity market indexes cannot be discerned from other factors affecting them over time.

Country-specific developments show significant variations (Figure A.2; Table A.2). The largest movements in money market rates and bond yields were observed in Switzerland, Japan, and Denmark, possibly reflecting the fact that policy rate cuts were more significant, or policy changes unexpected. NIRP announcements by the ECB were associated with relatively subdued drop in

\section{Figure 9. NIRP announcements: changes in selected financial variables over one-day window}

\section{A. Money market rates and bond yields}

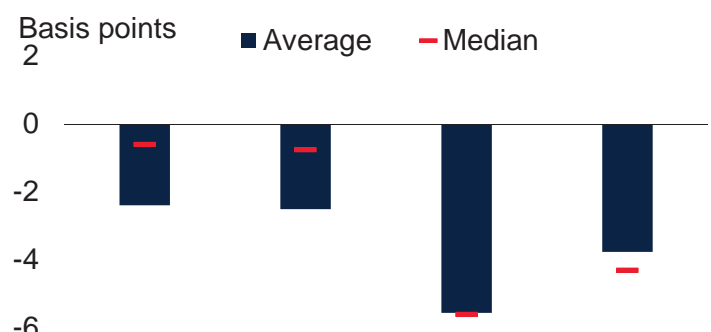

$-6$
B. Inflation expectations, exchange rates, and equities
Basis points average - Median Percent
2
2

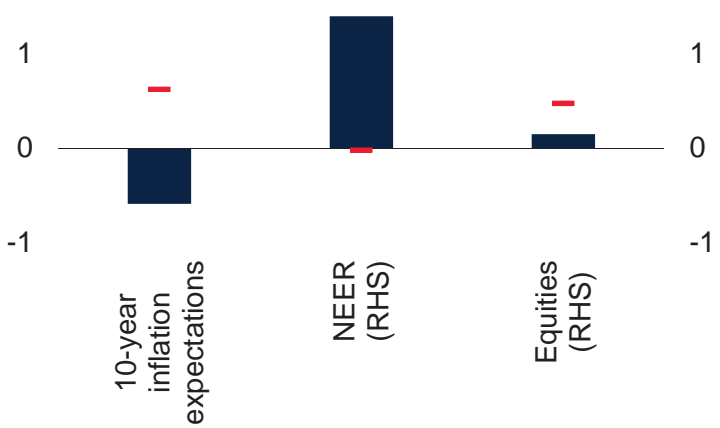

Sources: Bloomberg, Haver Analytics, European Central Bank, Riksbank, Danmarks Nationalbank, Swiss National Bank, Bank of Japan, Central Bank of Hungary, World Bank.

Notes: Basis points or percent change between closing values on the day before the NIRP announcement and closing values on the day of the announcement. Pooled average and median across NIRP announcements by five major central banks: the European Central Bank, the Bank of Japan, the Swiss National Bank, the Swedish Riksbank and Danmarks Nationalbank. The government bond yields are on benchmark bonds for each country, except for the European Central Bank events where they are from the ECB's euro area fitted yield curve. 10-year inflation expectations are derived from inflation swaps rates (not available for Switzerland). NEER is the nominal effective exchange rate; a decrease indicates depreciation. Equities are the main stock market index for each country, expressed in local currency. 
bond yields, probably reflecting the fact that complementary policies and forward guidance were on the whole less expansionary than previously expected by financial markets. Exchange rates and equity-market developments have also been mixed in the euro area.

\subsection{Comparison of NIRP with other monetary policies in the euro area: An event study}

A natural question to ask is whether the responses of key financial variables to NIRP announcements differ from those of other types of monetary policies. One approach could be to compare the initial market response following NIRP announcements with that following conventional rate cuts in positive territory and QE announcements. To do this, another event study in the context of the ECB policies is conducted. ${ }^{20}$ This event study is subject to the same caveats mentioned above.

This exercise leads to the following observations (Figure 10). First, compared with policy rate cuts during the easing cycle of the early-2000s, the reaction of money market rates and bond yields to recent NIRP announcements was qualitatively similar, but often smaller. This mainly reflects

Figure 10. ECB policy announcements: changes in selected financial variables over one-day window

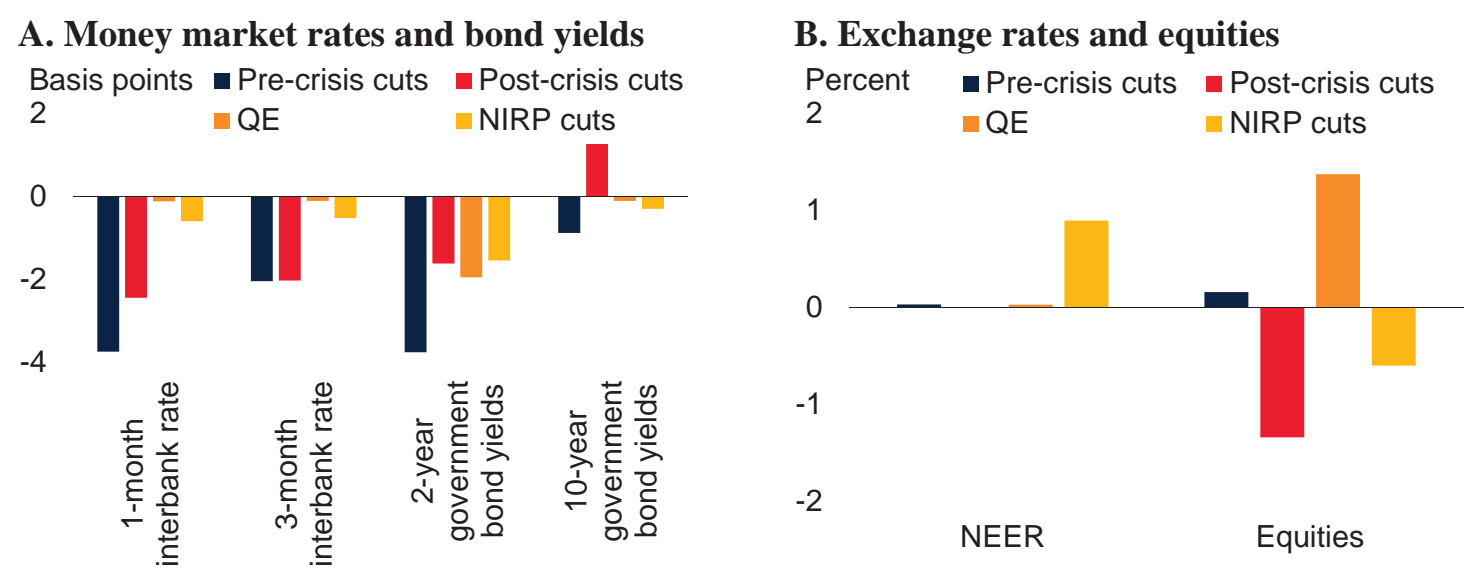

Sources: Bloomberg, Haver Analytics, European Central Bank, World Bank.

Notes: Variable definitions are the same as in Figure 9. Pre-crisis policy rate cuts includes seven cuts to the main refinancing operation (MRO) rate over the period 2001 to 2003. Post-crisis policy rate cuts includes twelve cuts to the MRO rate over the period 2008 to 2013 (a period that also included hikes to the MRO rate during 2011). QE announcements include nine official policy announcements or expansions of the following programs: the covered bond purchase program, the securities market program, the outright monetary transactions program, the asset-backed securities purchase program, the public sector purchase program, and the corporate sector purchase program. NIRP announcements include four announcements which have resulted in the ECB's deposit facility rate moving into, or further into, negative territory.

\footnotetext{
${ }^{20}$ The specific focus on the ECB reflects its systemic nature and the broad range of policy easing measures it undertook both prior and after the global financial crisis.
} 
smaller cuts in deposit rates and stable marginal refinancing operations (MRO) rate in the NIRP era. MRO rates were only cut by 25 basis points since the start of NIRP while deposit rates were reduced by 40 basis points.

Second, policy rate cuts in the immediate aftermath of the global financial crisis coincided with significant declines in short-term interest rates (and declines in long-term interest rates in some countries), likely reflecting the soothing effects of monetary policy accommodation amid substantial market jitters in the run-up and during the euro area debt crisis. Although based on a small number of events, the initial market reaction to NIRP suggests a broadly consistent pattern compared with previous interest rate cuts in positive territory, albeit with significant variations. Moreover, results associated with NIRP appear to be qualitatively similar to those of QE announcements with generally larger declines in short-term rates (Table A.1).

\section{How could NIRP affect financial stability?}

The impact of NIRP may be analogous to very low but positive policy interest rates in many respects, but NIRP could pose risks to financial stability, particularly if rates go substantially below zero or if NIRP are employed for a protracted period of time. Adverse consequences of NIRP could include erosion of profitability of banks and other financial institutions and excessive risk-taking by investors.

This section first examines the impact of NIRP on financial intermediaries and presents an event study analyzing changes in financial-sector variables following NIRP announcements. It then considers how NIRP could affect risk-taking behavior and valuation of assets. Given that the impact of NIRP on financial stability depends on the level of interest rates, it concludes with a brief discussion of how deep policy rates can go into negative territory.

\subsection{Impact on financial intermediaries}

Banks. Since banks may be unwilling or unable to pass on negative deposit policy rates to their customers without eroding their savings base, NIRP could put pressure on their profitability by narrowing net interest margins - the gap between commercial banks' lending and deposit rates (Hannoun 2015). This is particularly relevant for retail depositors, which could face lower costs of substituting currency for deposits than large businesses and institutional investors (McAndrews 2015). Recent empirical evidence suggests a positive relationship between short-term interest rates and net interest margins, with the adverse effect on profitability being particularly significant in a low interest rate environment (Claessens, Coleman and Donnelly 2016; Borio et al. 2015). ${ }^{21}$

The effect of narrowing net interest margins on bank profitability under NIRP depends among other factors on the source of bank funding and the degree of downward stickiness of retail deposit rates. Bernanke (2016a), for instance, argues that modestly negative short-term rates should not be

\footnotetext{
${ }^{21}$ Genay and Podjasek (2014) also find that a low interest rate environment is associated with decreased profitability for banks, but they estimate the effect to be economically small and outweighed by other macroeconomic factors.
} 
expected to have large effects on bank profitability if banks depend primarily on wholesale funding, large depositors, and foreign depositors. Banks that rely primarily on retail deposits, which exhibit limited interest rate pass through from NIRP would likely suffer larger margin compression than banks that rely mainly on wholesale funding. The fact that interbank market rates have moved deeper into negative territory than retail deposit rates, as documented earlier, highlights this differentiated impact. The effect of NIRP on bank profitability also depends on banks' ability to diversify income sources and raise bank fees.

The euro area Bank Lending Survey of April 2016, found that there is a perception among banks that NIRP has already hurt or is expected to hurt profitability (Figure 11). For instance, more than 80 percent of banks participating in the survey stated that the negative deposit facility rate contributed to a decrease in their net interest income (ECB 2016b). According to the survey, the asset purchase programs of the ECB also reduced net interest margins and profitability of banks, despite improving capital gains. The decline in euro area bank equity prices since mid-2015 could partially be ascribed to market concerns about future profitability.

However, bank profitability depends more fundamentally on the overall health of the economy, affecting both the volume of lending and its quality. ${ }^{22}$ Stronger growth should help reduce nonperforming loans, reinforce banks' capital base and steepen the yield curve, which are all important factors supporting lending and profitability conditions (Shin 2016). Evidence suggests that net income of large euro area banks have not been significantly affected so far, thanks to lower impairments and higher non-interest income (ECB 2016c).$^{23}$ Across NIRP countries, bank lending margins remain within post crisis ranges, despite showing some signs of compression.

Recent empirical research documents an increase in loan growth upon the introduction of NIRP in the euro area. Rostagno et al (2016) show that under NIRP, euro area banks have become more likely to turn extra reserves into lending or bond purchases, and that total lending to companies has gone up relative to a counterfactual scenario. The ECB's July 2016 Bank Lending Survey also indicates that loan supply conditions for both enterprises and households continued to improve during the first half of 2016 (ECB 2016d). Across NIRP economies, credit growth has generally improved, albeit sluggishly in most cases.

\footnotetext{
${ }^{22}$ Beyond profitability, European banks appear to have been able to enhance somewhat their shock-absorbing capacity in recent years. According to the latest stress test results on 51 large European banks, 43 maintained a common equity tier 1 ratio above 8 percent in a severe recession scenario, showing improved resilience from similar tests in 2014 (EBA 2016). Having said that, concerns remain about euro area banks because of a large stock of legacy assets and non-performing loans (World Bank 2016b).

${ }^{23}$ Draghi (2016) emphasized that the ECB had "no evidence that [negative interest rates] hampered the transmission of monetary policy, and when we look at bank profitability, we see that 2015, the first full year with negative interest rates has not affected, or has not caused negative interest income, net interest income going down. As a matter of fact, it went up." He also noted that "Now, of course we've got to be cautious here because we talk about the aggregate of the banking system in the euro area, and of course aggregates may actually conceal different realities." Cœuré (2015) argued "... whether bank profitability really falls when policy rates are lowered depends more generally on the slope of the yield curve, on banks' investment policies and on factors driving non-interest income."
} 
Figure 11. Banking sector performance

\section{A. Impact of ECB's NIRP on banks}

Net percent $\quad$ Past six months $\square$ Next six months

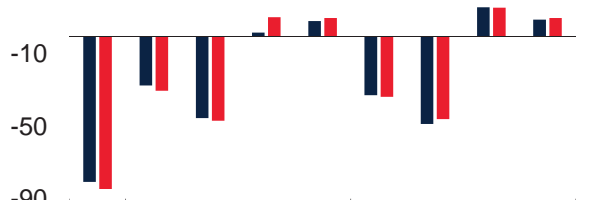

$-90$

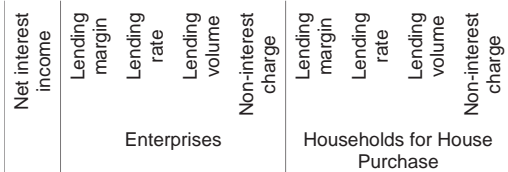

\section{Bank equity prices}

Index, Jan $2014=100$

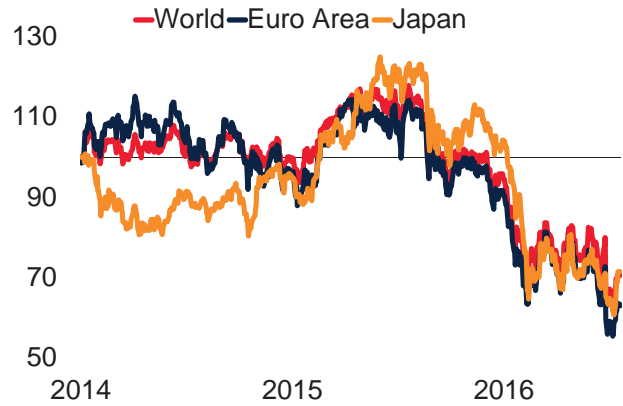

E. Interest margins on corporate lending Percentage points

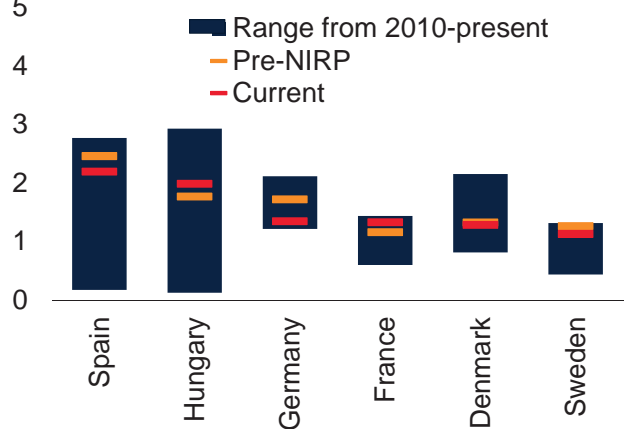

\section{B. Impact of ECB's QE on banks}

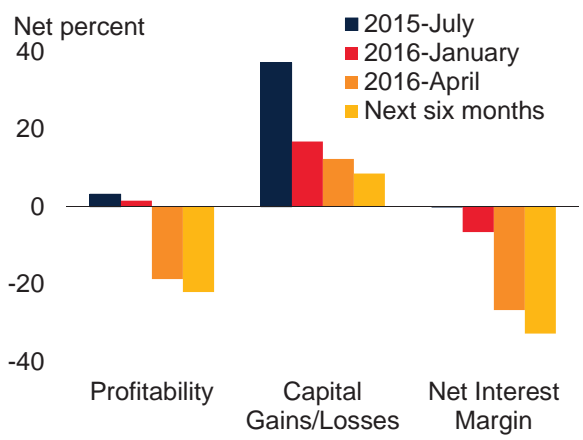

D. Interest margins on household lending

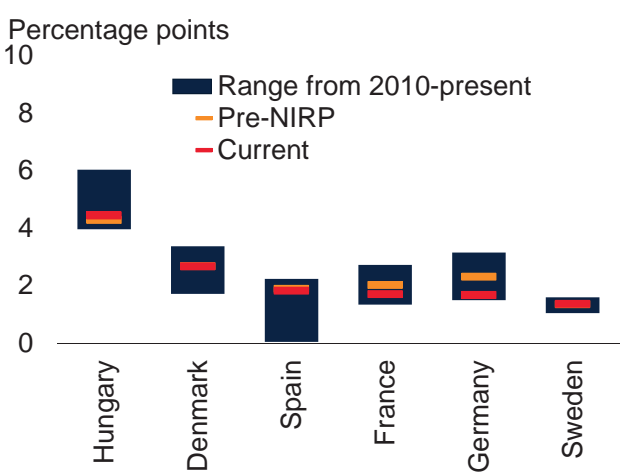

F. Credit growth

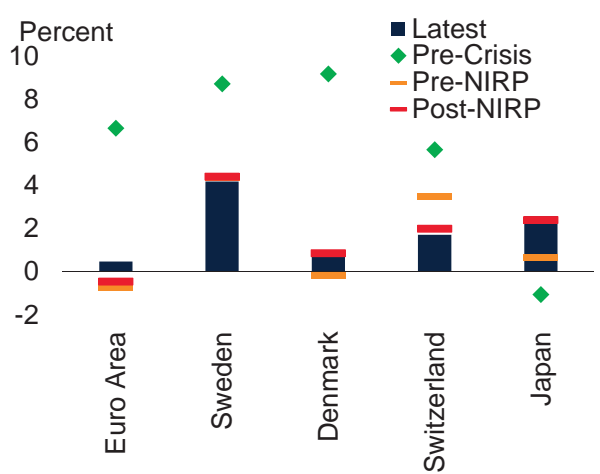

Sources: Bloomberg, European Central Bank (2016b), World Bank.

A. B. Results from ECB's Bank Lending Survey in April 2016. Questions start as: "Given the ECB's negative deposit facility rate, did or will this measure, either directly or indirectly, contribute to..." Net percent is calculated as the difference between the sum of responses mentioning "increased considerably" and "increased somewhat" and the sum of responses mentioning "decreased somewhat" and "decreased considerably", divided by the number of responding banks which did not reply "not applicable."

C. Last observation July 2016.

D. E. Lending margins are measured as the difference between rates applied to new household/non-financial corporation loans and a weighted average rate of rates applied to new deposits from households and non-financial corporations.

F: Year-on-year growth of credit to households and non-financial corporations. Pre-Crisis stands for average period between Jan. 2003 and Dec. 2007. Pre-NIRP stands for period between Jan. 2010 and beginning of NIRP date. Post-NIRP stands for the period between the beginning of NIRP and last observation. Last observation is March 2016 for Switzerland, May 2016 for Japan, and April 2016 for the other economies. 
Although a significant adverse impact of NIRP on bank profitability is yet unclear, persistently negative rates could lead to harmful effects over time and undermine the transmission of monetary policy. To mitigate this risk, central banks have adopted specific complementary measures. For example, the ECB's implementation of NIRP was part of a package of measures including expanded asset purchases, and perhaps most importantly for banks' profitability, the second generation of Targeted Long-term Refinancing Operations (TLTRO). ${ }^{24}$ The TLTRO program allows banks to borrow at zero or negative fixed interest rates, conditional on their expansion of credit to the private sector. If NIRP are seen as a tax on banks' deposits, this measure could be seen as subsidized borrowing. Should banks increase their lending enough to get the full interest rate discount on their TLTRO borrowing (i.e., a rate of -0.4 percent), the effect of negative central bank deposit rates on bank earnings could be offset, depending on the respective size of excess reserves and new refinancing operations.

Tiered deposit rate systems, in which negative rates apply only to a part of excess reserves, have been seen as another option to alleviate pressure on banks under NIRP. These systems are in place in Denmark, Switzerland and Japan. IMF (2015c) argues that the tiered system of SNB, along with banks' passing on the negative rates to wholesale depositors, mitigated the effects of negative interest rates on banks' profits in Switzerland. SNB (2015) claims that the negative rate levied on sight deposits at the central bank over set thresholds had a small impact on overall earnings for domestically-focused banks.

Non-bank financial institutions. Institutional investors, including insurance companies, asset managers, and pension, mutual and sovereign wealth funds, often maintain portfolios with large government bond holdings in pursuit of stable, risk-adjusted returns to meet long-term obligations. Insurance companies and pension funds might also be constrained to hold government bonds by prudential requirements. Under persistently low or negative-yielding bonds, pension and life insurance companies may struggle to generate adequate returns. In addition, some products such as fixed rate annuities might become less attractive and problems associated with mispriced options could be exacerbated (Hannoun 2015). Equity returns and the solvency of life insurers might hence deteriorate and become increasingly sensitive to interest rates, as observed in the United States since the global financial crisis (Berends et al. 2013). Differences in tax regimes and regulations imply that the sensitivity to interest rate risks could vary considerably across jurisdictions (Geneva Association 2015).

\footnotetext{
${ }^{24}$ In addition to the TLTRO, the package of measures includes expanded asset purchases through its Public Sector Purchase Program (PSPP), Asset Backed Securities Purchase Program (ABSPP), and Corporate Sector Purchase Program (CSPP).
} 
Figure 12. Insurance company equity prices

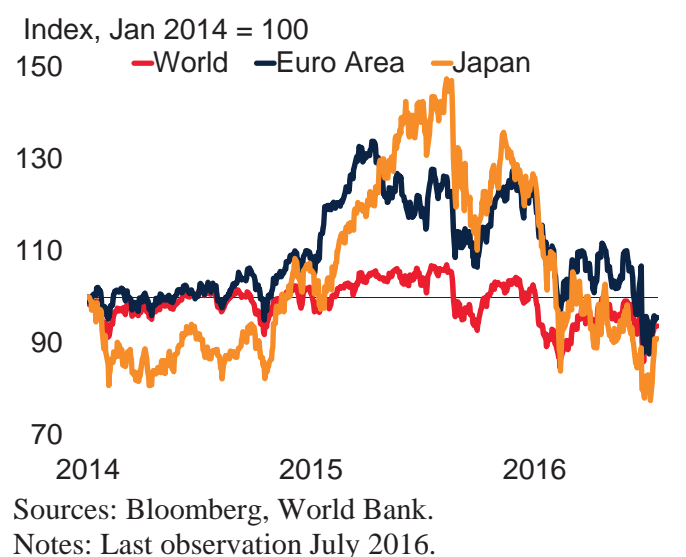

Consistent with the growing challenges faced by the sector, equity prices of insurance companies in the euro area and Japan have moved down during the NIRP period (Figure 12). ${ }^{25}$ However, insurance companies in Europe have taken actions to improve their solvency positions in recent years, partly in preparation to a new regulatory regime (ECB 2016c). Japan's experience with more than 20 years of very low nominal interest rates also illustrates that substantial changes in product portfolio and allocation of assets can help the insurance industry adjust under challenging circumstances (Nieder 2013).

Money market funds. Money market funds make conservative investments in cash-equivalent assets, such as highly-rated short-term corporate or government debt, to provide investors liquidity and capital preservation while paying a modest return. Because of their business model, these funds may face formidable challenges even at very low but positive rates. Specifically, money could flow out of these funds as very low but positive returns on short-term safe assets would likely produce negative net-of-expense nominal returns to money market fund investors (Di Maggio and Kacperczyk 2016).While these funds aim to avoid reductions in net asset values, this objective would not be attainable if rates in the market are negative for an extended period.

However, the experience with NIRP has so far indicated no major adverse impact on money market funds. For example, the Danish experience suggests that money market funds can pass through the negative rates without significant disruptions. Huttl (2014) documents that the volume of transactions in money markets declined somewhat upon introduction of NIRP, but this was mainly a reflection of an ongoing trend already started in 2010. In addition, the European money market fund sector has been growing amid NIRP and some funds have received continued inflows (ECB

\footnotetext{
${ }^{25}$ Gibas et al. (2015) present evidence on the adverse impact of low interest rates on some Swedish financial institutions, including life insurance companies. The growing systemic importance of life insurance companies and pension funds in the European financial sector could magnify the effect of NIRP on financial stability (IMF 2016c).
} 
2016c). Moreover, the maturity of the debt held by these funds has not changed dramatically under NIRP, suggesting that they have not altered significantly their business model and weathered the low interest rate environment relatively well.

Potential disruptions to the functioning of money markets are likely to be an important reason why NIRP are not seen as a preferred policy option in the United States. ${ }^{26}$ In particular, U.S. money market funds operate under rules that make it difficult for them to pay negative interest rates. These funds are usually considered to be a more important component of the financial system in the United States in comparison with Europe. ${ }^{27}$ A study by the Federal Reserve explores the market implications of low, zero, and modestly negative rates on excess reserves (Federal Reserve Board 2010). It concludes that reducing interest rates on excess reserves (IOER) to close-to-zero levels would trigger outflows from money market funds. Reducing the IOER to zero would accelerate the outflows and lead to revenue losses for Treasury-focused funds. Setting the IOER modestly below zero would imply further reductions in profitability of money market funds and increase the probability that some of them would become unviable. In addition, the auction process for new U.S. Treasury securities does not currently permit participants to submit bids with negative rates, adding to the operational difficulties in implementing NIRP.

\subsection{Changes in financial-sector variables following NIRP: An event study}

An event study is conducted to examine the changes in key financial-sector variables following the announcements of NIRP. As in section 4.4, the "event" is defined as a deposit policy rate cut announcement into (or within) negative territory, using a one-day event window around the announcement. The same caveats above apply to the interpretation of these event study results.

Despite the presumption of adverse effects, the initial reaction of bank equity prices to NIRP announcements has been mixed, while financial sector Credit Default Swap (CDS) spreads have generally declined (Figure 13). The average change in bank equity prices was negligible on the

\footnotetext{
${ }^{26}$ In both the U.S. and U.K., there have been discussions about the possible use of NIRP. For instance, Mankiw (2009) argued that the U.S. Federal Reserve should have considered this possibility during the Great Recession. Bernanke (2016a) and Kocherlakota (2016b) suggested that that the use of negative interest rate policies could be appropriate in the United States under certain circumstances. The BoE also discussed the feasibility of negative policy rates in an official letter to the Treasury Committee noting (Bank of England 2013): “... there are no significant technical or operational obstacles that would prevent the Bank from implementing a negative level of Bank Rate." However, Governor Mark Carney (2016a) was cautious about the use of NIPR because of financial stability considerations: “... As we have seen elsewhere, if interest rates are too low (or negative), the hit to bank profitability could perversely reduce credit availability or even increase its overall price." Carney (2016b) repeated the same message: "The MPC is very clear that 'lower bound' is a positive number and we will continue to be clear on that... I am not a fan of negative rates. We see the negative consequences through the financial system in other jurisdictions. We have other options available if more stimulus is needed."

${ }^{27}$ Cœuré (2015), for instance, states "This is [evidence that the lower interest rate environment in the United States adversely affects money market funds], however, less of a concern in Europe where money market funds are not central to the financial system."
} 
Figure 13. NIRP announcements: changes in financial sector variables over one-day window

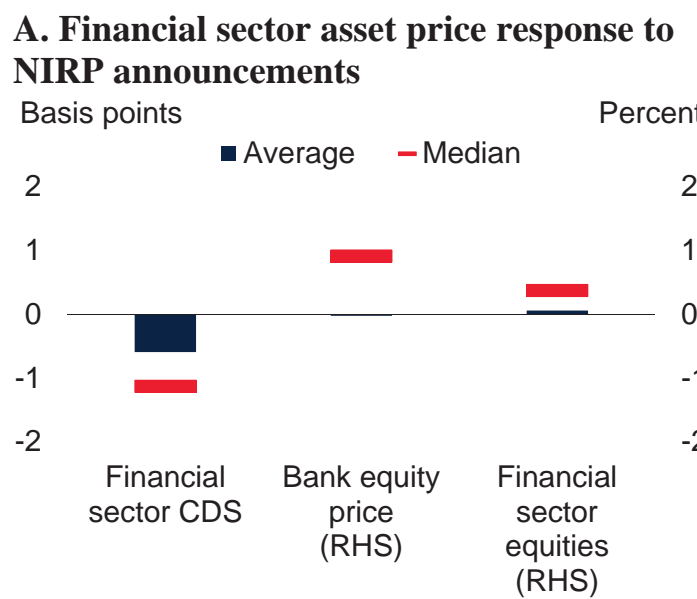

\section{B. Financial sector asset price response to NIRP announcements across countries}
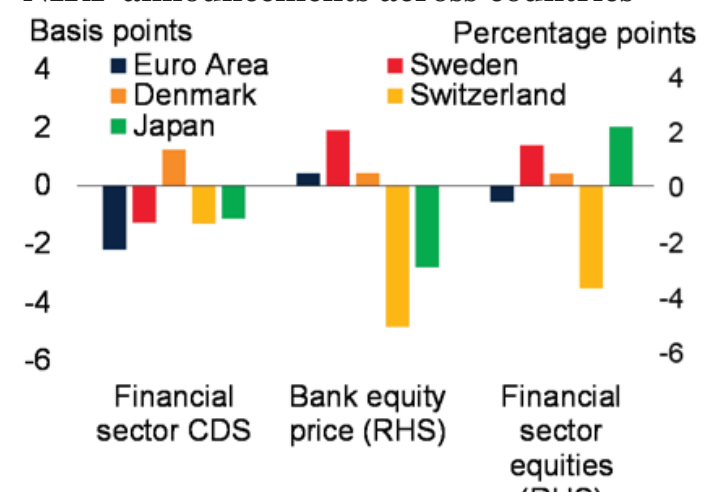

(RHS)

Sources: European Central Bank, Bank of Japan, Swedish Riksbank, Swiss National Bank, Danmarks Nationalbank, Central Bank of Hungary, Bloomberg, Haver Analytics, and World Bank.

Notes: Bank equity price is the percentage change of the largest bank in each country or area on the given announcement days. Financial sector equities is the broad financial sector index for each nation or area. Financial sector CDS is, for all the events caused by central banks in Europe, a Europe-wide senior bank debt CDS index, and, analogously for Japan.

announcement day, while the median increase was about 1 percent. In particular, the unanticipated decision of the SNB in January 2015 and of the Bank of Japan in January 2016 were accompanied by declines in bank equity prices. In the SNB case, this partly reflected a sharp appreciation of the Swiss Franc, which put pressure on earnings and led to a significant sell off in equity markets more generally. Regarding financial-sector CDS spreads, declines were broad-based across countries and events - with the noticeable exception of the NIPR announcement by the ECB on December 2015, likely a reflection of markets' expectation of more aggressive easing.

If the event window is extended from one day to one month, the evolutions of CDS spreads and bank equity prices are mixed, with a widening range of outcomes across events (Figure A.3). The SNB decision in January 2015 was followed by a persistent decline in equity prices against the backdrop of a significant appreciation of the Swiss Franc. The evolution of CDS spreads in the euro area after the ECB failed to ease as aggressively as expected in December 2015 is also noticeable. In the month following that ECB NIRP announcement episode, spreads increased back to levels prevailing prior to the ECB's hint in October 2015 of further policy easing, and started moving rapidly higher after that. These developments suggest that aggressive policy easing by the ECB, including NIRP, tends to relieve commercial bank stress, rather than contribute to it. NIRP announcements by the Swedish and Danish central banks have led to broadly positive responses. For example, bank equity prices rose by an average of 4 percent during the month following those policy decisions. 


\subsection{Other financial stability and macroeconomic concerns}

Excessive risk-taking. NIRP are seen as a natural extension of unconventional monetary policies that have been implemented over the past eight years. There has been an extensive debate about the financial stability implications of these unconventional monetary policies, including QE programs. Some argue that these unconventional policies could lead to a buildup of leverage, or asset bubbles by encouraging excessive risk taking by financial market participants (Caruana 2013; Feldstein 2013; and Stiglitz 2016).

Bank and non-bank investors may be encouraged by negative rates to take excessive risk in their search for yield (Hannoun 2015). Recent research also documents an inverse relation between short-term interest rates and bank risk-taking. ${ }^{28}$ Greater risk-taking may contribute to the formation of asset bubbles, which could be particularly damaging for the real economy if they take place in the housing market (Claessens, Kose and Terrones 2012; Mian, Sufi and Verner 2015). House price increases have so far remained moderate in most NIRP economies, albeit showing a noticeable upward trend and relatively high historical valuation in a few countries (Figure 14). Equity valuations have risen in varying degrees and price-earning ratios have generally picked up. In addition, the share of government debt in NIRP economies trading at negative yields has been increasing in recent months. However, there is no conclusive evidence as yet of a significant and broad based increase in leverage, or excessive asset price valuations which could signal looming risks of financial instability, while regulation and prudential standards have been reinforced since the global financial crisis.

Anomalies in the valuation of returns and payments streams. As interest rates approach zero, the calculation of present values of future cash flows becomes increasingly sensitive to the discount rate. For example, one way to describe the problem for pension and life insurance companies is to state that the steep drop in discount rates implies a sharp rise in the present value of their liabilities. This could become a contentious issue in the negotiation of fair value in legal settlements. As discount rates of zero or less have no "economic" meaning, a prolonged period of negative interest rates would create ambiguities for the valuation of assets and liabilities. Moreover, the issuance of interest bearing securities at negative yields may face legal and operational challenges (Garbade and McAndrews 2015).

Broader macroeconomic and policy challenges. Some claim that unconventional policies, including QE and NIRP, could also lead to unintended macroeconomic and policy challenges. For example, they argue that unconventional policies might lead to misallocation of resources and distortion of income and wealth distributions (White 2012; Dervis 2016; Stiglitz 2016). Some claim that the use of low or negative interest rates for a prolonged period could unduly hurt savers, risk central bank credibility, weaken the resolve to repair and reform financial entities, and delay

\footnotetext{
${ }^{28}$ Dell'Ariccia, Laeven, and Suarez (2013) and Jimenez et al. (2014) present detailed analyses of the links between interest rates and bank risk-taking.
} 
Figure 14. Asset prices under NIRP

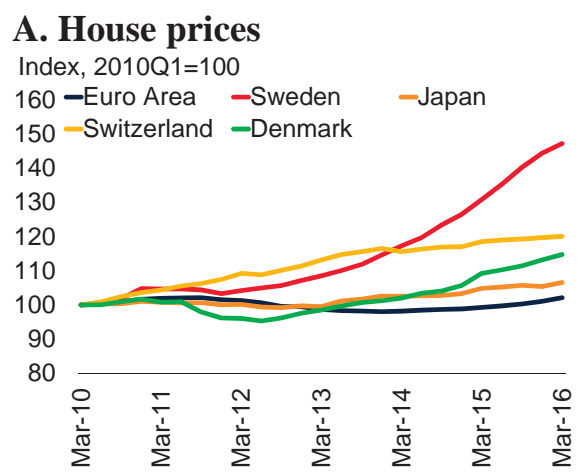

C. Equity prices

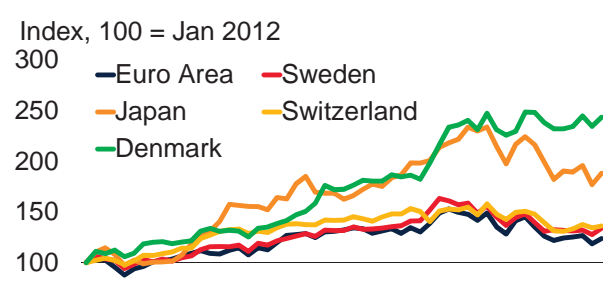

50

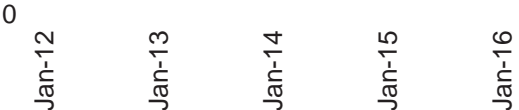

E. Share of government debt trading at negative yields over time
Percent
- Europe
- Japan
80

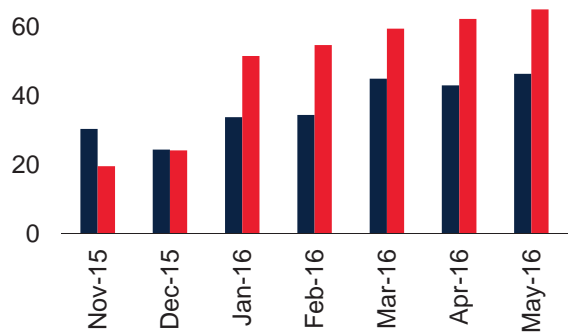

\section{B. House price to income ratio}

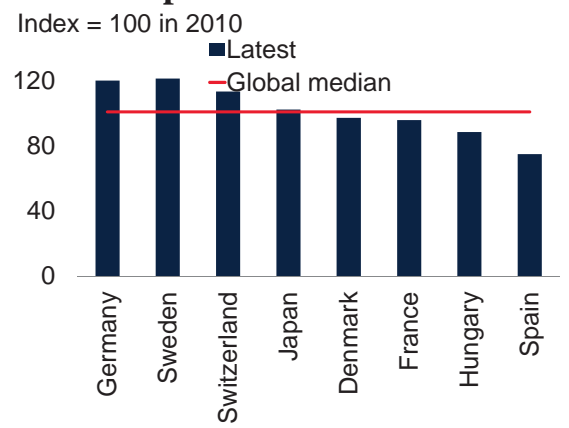

\section{Price-to-earnings ratio}

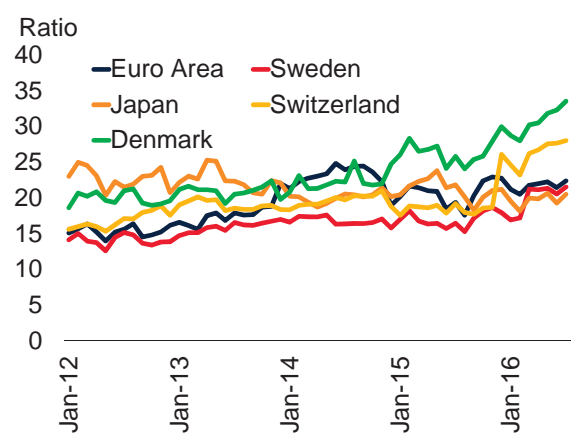

F. Share of government debt trading at negative yields by maturity

Percent of debt by market value

50

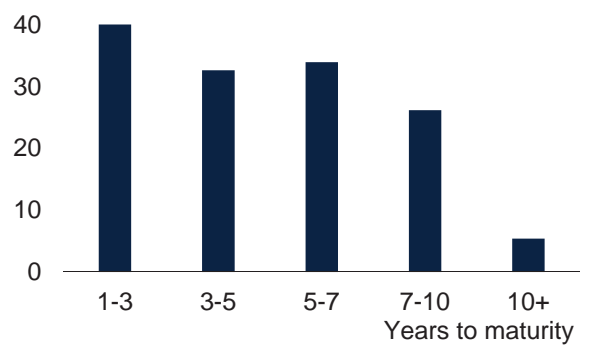

Sources: Bank for International Settlements, Bloomberg, European Central Bank, MSCI, J.P. Morgan, World Bank.

A. Real residential property prices, covering all types of dwellings in the whole country, in both new and existing dwelling markets. Last observation is 2016 Q1 for Switzerland and 2015 Q4 for the rest.

B. Price-to-income ratio, index, 2010=100. Last observation is $2015 \mathrm{Q} 4$.

C. Last observation is July 2016.

D. Earnings are trailing twelve month earnings. Last observation is July 2016.

E. Data from the J.P. Morgan Global Developed Market Bond Index. "Europe" includes Belgium, Denmark, France,

Germany, the Netherlands, Spain, and Sweden. Includes all bonds in the index with greater than one year maturity. Last observation is May 2016.

F. Includes: Belgium, Canada, Denmark, France, Germany, Italy, Japan, the Netherlands, Spain, Sweden, the United Kingdom, and the United States. 
necessary fiscal adjustments and structural reforms (Hannoun 2015; Folkerts-Landau 2016; Fink 2016). ${ }^{29}$

\subsection{How low can negative rates go?}

NIRP raise the question of how low negative rates can go before market distortions become significant enough to threaten financial stability. At the extreme, if central banks pushed policy rates too far into negative territory, there is a risk that large sectors of the economy could become cash-based.

The cost of storage, insurance, safekeeping and transportation of cash, along with the price of convenience, are key in determining the effective lower bound of interest rates. According to some estimates, the current cost of storing cash could range between 0.2 and 1.3 percent, depending in part on the size of available bills (Rostagno et al. 2016) ${ }^{30}$ Regarding the cost of convenience, it could be approximated by credit and debit card interchange fees. In the European Union, these fees have recently been capped at 0.3 percent, slightly above the cost that is estimated to make merchants indifferent between cash and card payments (European Commission 2015).

The effective lower bound also depends on a variety of country-specific factors. For example, a large presence of financial institutions that are likely to be affected adversely by low or negative interest rates, such as money market funds, pension, and insurance companies, could potentially impact the lower bound of policy interest rates. The average size of deposits could be another factor determining the lower bound, as the cost of storing cash increases with its amount. Finally, demographics might also be an important variable, as a greater share of households dependent on interest income could make banks more reluctant to lower deposit rates.

Given the multitude of the factors in play, it is unclear what the effective floor for NIRP is in each jurisdiction. However, the fact that the deposit policy rate has reached -0.4 in the euro area, -0.5 percent in Sweden, and -0.75 in Denmark and Switzerland without any readily discernible distortions so far suggests that the limit might be lower, albeit to various degrees across countries.

\footnotetext{
${ }^{29}$ NIRP is expected to reduce savings and promote investment and consumption in the short-run. However, NIRP could have the opposite impact on savings if households end up increasing their savings to smooth consumption over time. In this context, negative rates could induce households to increase savings in order to compensate for a potential loss of future pension income (Fink 2016; Cliffe 2016).

${ }^{30}$ Financial innovations to circumvent negative rates might eventually lower the opportunity cost of holding cash and impose a different floor on rates (Svensson 2015; Garbade and McAndrews 2012; Alsterlind et al. 2015). These types of financial innovations could include the creation of new institutions to handle and store cash on behalf of depositors. It could also include new behavioral responses, such as making advance tax payments to the government and earn a zero return until a refund is received from the government, thus avoiding negative rates (McAndrews 2015).
} 
Figure 15. Euro area deposit growth

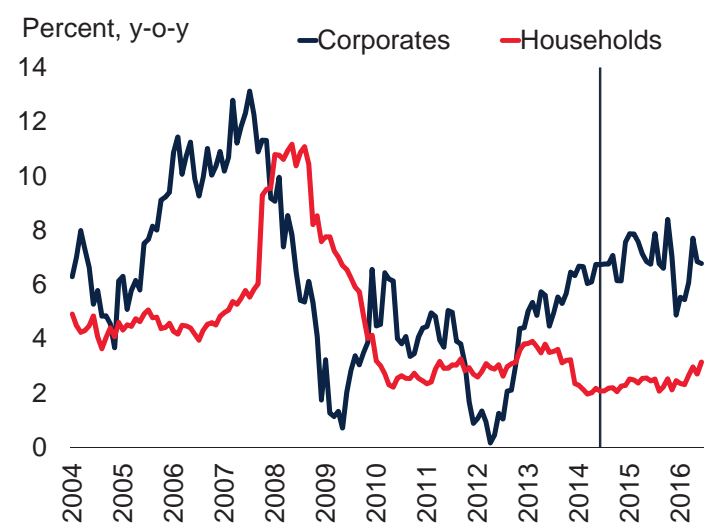

Sources: European Central Bank, World Bank.

Notes: Year-over-year growth rates of outstanding deposits at the end of the period (stocks). Outstanding deposits at all euro area Monetary Financial Institutions. The vertical line indicates the start of NIRP (June 2014) in the euro area. Last observation is May 2016.

In the euro area, deposits continue to grow at a broadly similar pace before and after NIRP, showing no sign of disintermediation risk as retail deposit rates stabilize around zero (Figure 15). More generally, there is no evidence as yet of a significant increase in cash hoarding across NIRP countries (Malinovskaya and Wessel 2016).

\section{What are the implications of NIRP for emerging market and developing countries?}

As the United States embarks on a gradual normalization of policy interest rates, NIRP along with other unconventional expansionary policies by major central banks could help contain the ensuing increase in global interest rates and support the appetite for riskier, higher-yielding assets, including those of EMDEs, supporting capital flows to these economies. While negative interest rates in Europe have already led to a notable pickup in euro-denominated bond issuances by EMDEs, increasing yield differentials between Europe, Japan and the United States could also maintain upward pressure on the U.S. dollar. The broad-based U.S. dollar appreciation since 2014 has been mirrored in considerable strain on some EMDE currencies, contributing to a higher cost of debt servicing and broader balance sheet pressures. This has been reinforced by deteriorating growth prospects and rising credit risks, particularly among commodity-exporting EMDEs.

This section first analyzes how NIRP could have an impact on financing conditions for EMDEs. It then considers the results of an event study on the responses of EMDE financial variables to NIRP announcements. It concludes with a brief discussion of policy responses to possible risks associated with NIRP. 


\subsection{Potential impact on financing conditions for EMDEs}

Cross-border impact of NIRP. Unconventional monetary policies, including NIRP, might affect capital flows to EMDEs through various channels. In particular, low or negative bond yields in NIRP countries could encourage further portfolio balance adjustments. Faced with negative shortterm rates, international investors are encouraged to search for higher yields, both domestically (higher risk and longer maturity assets) and internationally (similar duration but higher returns). This should help induce capital flows to EMDEs, maintain favorable financing conditions, and mitigate adverse effects of rising interest rates in the United States (Arteta et al. 2015).

In the post-crisis period, the use of highly accommodative monetary policies in some advanced economies coincided with an acceleration in capital inflows to EMDEs. Although there is no consensus on the size of the spillover effects, a number of studies show that quantitative easing (QE) measures were mostly associated with stronger capital inflows (Lim, Mohapatra, and Stocker 2014; Fratzscher, Duca, and Straub 2013; Ahmed and Zlate 2014). Some studies suggest that QE policies also supported EMDE equity prices while compressing government, corporate bond, and CDS spreads (Chen et al. 2011). Over time, large capital inflows could be associated with rapid credit growth and rising private sector leverage in some EMDEs. ${ }^{31}$

Role of NIRP economies in EMDE funding. Negative rates in Europe could be partly contributing to a gradual shift in the sources of funding for some EMDEs, from U.S. dollar- to eurodenominated debt instruments. Since the start of the ECB's QE and implementation of NIRP, EMDE borrowers have increased the volume of bond issuance in European markets, taking advantage of exceptionally low borrowing costs (Figure 16). In an effort to compensate for negative or extremely low interest rates at home, European insurance companies and other institutional investors have also shown increased appetite for higher-yielding investment-grade EMDE debt. In contrast, cross-border lending by European banks to EMDEs has stalled, equity markets underperformed and flows to emerging market bond and equity flows continued to stagnate.

EMDE regions that could benefit the most from low interest rates in the euro area include Europe and Central Asia (which has the largest share of capital inflows supplied by the euro area), followed by Latin America and the Caribbean (through FDI), Sub-Saharan Africa (primarily bank flows), and the Middle East and North Africa (portfolio and bank flows). The share of capital inflows originating in the euro area is significantly lower in East Asia and the Pacific, and South Asia.

\footnotetext{
${ }^{31}$ Using cross-country panel data, Arslan and Taskin (2014) and Lane and McQuade (2013) provide evidence of a positive correlation between capital inflows and domestic credit growth.
} 
Euro area banks play a major role in the provision of syndicated bank loans to EMDEs, accounting for about 23 percent of total bank flows to these countries, compared to 10 percent for U.S. banks. However, even when intermediated through euro area banks, syndicated loans remain primarily denominated in U.S. dollars, particularly to Latin America, Africa, and the Middle East and Asia. Europe and Central Asia is the only region where the euro surpasses the U.S. dollar as a currency of denomination for cross-border bank flows.

Risks associated with monetary policy divergence. Increasingly divergent monetary policies across major reserve currencies have partly contributed to a broad-based appreciation of the U.S. dollar, which has been accompanied by considerable pressure on some EMDE currencies. This pressure has contributed to a higher cost of debt servicing and rising credit risks (Hofmann, Shim,

\section{Figure 16. Capital flows and asset prices in EMDEs}

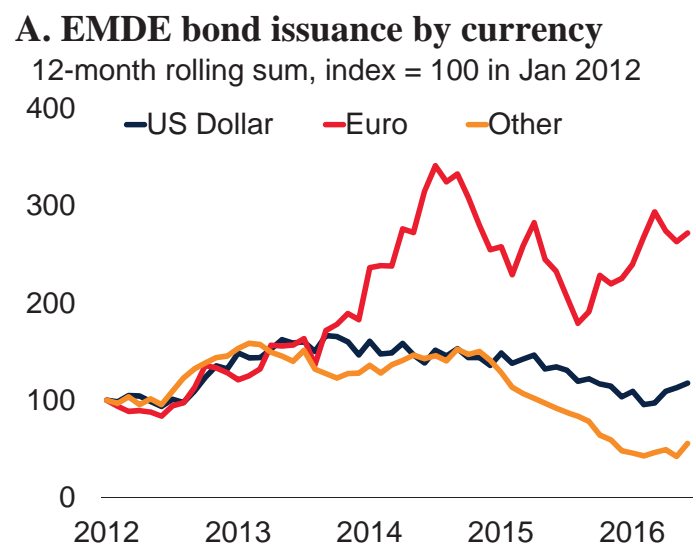

E. Share of inflows accounted by euro area residents

Percent of regional total

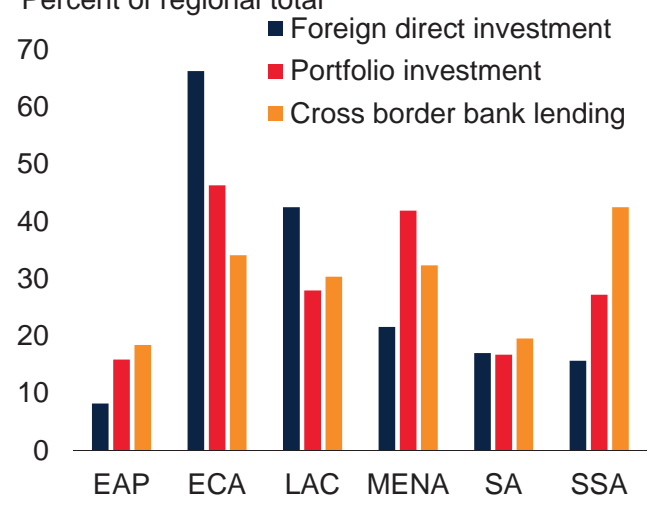

B. EMDE total bond issuance

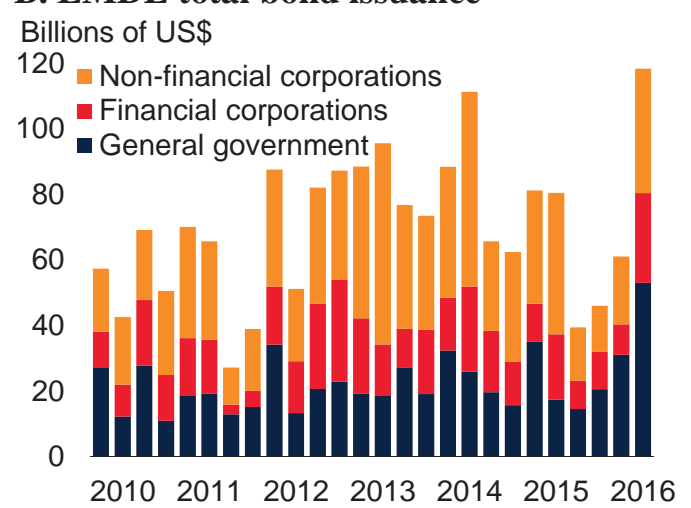

F. Currency denomination of cross-border bank lending in EMDEs

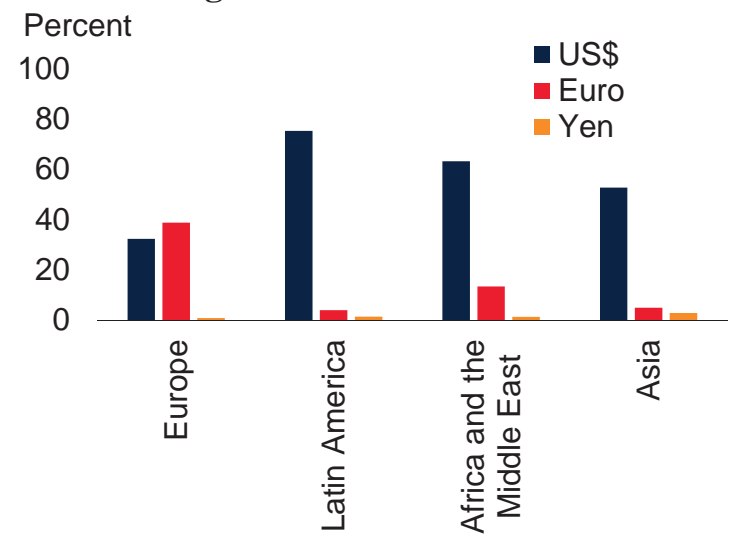

Sources: World Bank, Dealogic, Bloomberg, Bank for International Settlements, Adjiev and Takats (2016).

A.B. Bond issuance expressed in current U.S. dollar. Last observation is June 2016.

C. EAP is East Asia and the Pacific, ECA is Eastern Europe and Central Asia, LAC is Latin America and the Caribbean, MENA is the Middle East and North Africa, SA is South Asia, and SSA is Sub-Saharan Africa. Total portfolio investment data are as of June 2015. Foreign direct investment data are as of December 2014. Bank claims are as of December 2015.

D. Currency positions of cross-border bank lending in 2014Q4. 
Figure 17. Private sector credit and growth in EMDEs

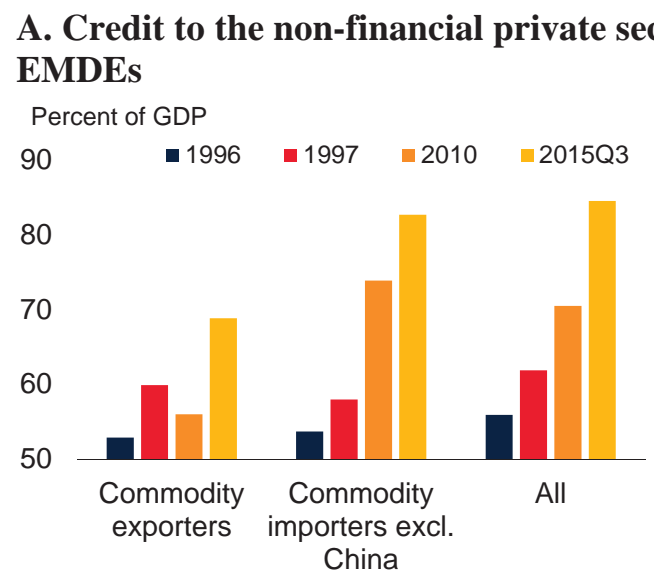

\section{B. Growth during develeraging episodes}

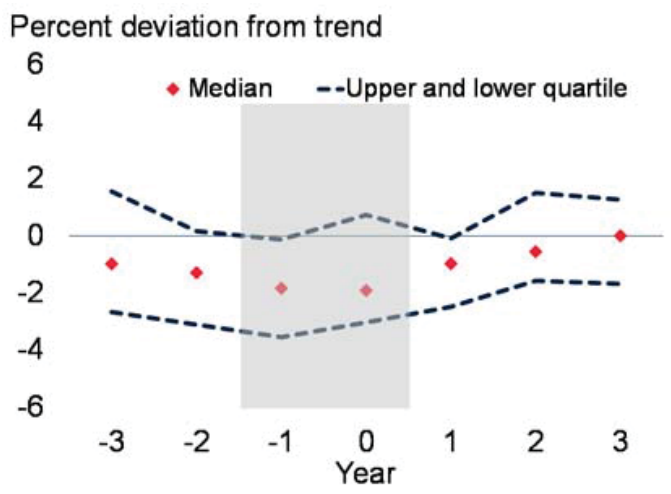

Sources: Bank for International Settlements, World Bank.

A. Simple average of claims (from residents and non-residents) on the non-financial private sector in 14 emerging markets and developing countries. Commodity exporters include Argentina, Brazil, Indonesia, Malaysia, Russia, Saudi Arabia, and South Africa. Commodity importers include China, Hungary, India, Mexico, Poland, Thailand, and Turkey.

B. A deleveraging episode is defined as an episode during which the cyclical component of the nonfinancial private sector credit-to-GDP ratio in the trough year is lower than -1.65 times its standard deviation. The cyclical components of the start of an episode fall below -1 times its standard deviation and end in a trough year when the private sector credit-to-GDP ratio starts to rise in the following years. " 0 " is the end (trough) year of the deleveraging episode. Median value (orange diamond) and the upper and lower quartiles (green dashed lines) of credit to the private sector during a deleveraging episode. It shows the cyclical component of real GDP in percent of its trend (based on a Hodrick-Prescott filter).

and Shin 2016). NIRP in Europe and Japan could lead to further volatility in currency markets and renewed upward pressure on the U.S. dollar, with repercussions for EMDEs.

The U.S. dollar plays a unique role in the international transmission of monetary policy shocks (Rey 2015). For instance, episodes of U.S. dollar appreciation tend to coincide with bank deleveraging and tighter global financial conditions (Bruno and Shin 2015; IMF 2015a). In the past, periods of rapid dollar appreciation have also been associated with a greater incidence of financial crises, such as in Latin America during the first half of 1980s and in Asia during second half of the 1990s. In the latter episode, countries with currencies tightly connected to the dollar experienced sudden stops of capital inflows and sharper economic downturns. Since the late 1990s, the share of both private and public debt denominated in foreign currency, and the number of countries with currency regimes tightly linked to the U.S. dollar, have declined.

However, foreign currency exposures are still elevated in some countries, especially in commodity exporters, as well as importers that have received large capital inflows since the end of the global financial crisis. Countries with significant short-term dollar-denominated debt are particularly vulnerable to rollover and interest rate risks and a drying up of foreign exchange liquidity (Chow et al 2015). More generally, high and rising private sector debt has become a growing source of vulnerability in EMDEs (Figure 17). While credit growth has been most pronounced in commodity exporting countries, nearing the pace associated with past credit booms, credit-to-GDP ratios also 
remain elevated in importing countries, with some close to levels that have in the past been associated with episodes of financial stress (World Bank 2016a). Rising leverage tends to increase the probability of capital flow reversals (Mendoza 2010; Elekdag and Wu 2011) and make recessions more severe in the presence of financial stress (Claessens, Kose and Terrones 2012).

Risks associated with deteriorating fundamentals in EMDEs. Macroeconomic fundamentals in EMDEs have weakened in recent years (Figure 18). While EMDEs continue to grow faster than advanced economies, the growth differential has narrowed. And credit risks have increased as sovereign ratings have been downgraded in a context of a growing stock of EMDE bonds maturing in the near term, raising roll-over risks. All these factors have reduced the relative attractiveness of EMDE assets. This could limit potential gains and increase risks associated with exceptionally favorable financing conditions in NIRP countries. EMDE growth has slowed for five consecutive years, reaching in 2015 its slowest pace since the global financial crisis. The slowdown has been significantly more pronounced than previously expected, reflecting a combination of external and domestic headwinds.

Weak global trade and declining commodity prices weighed heavily on EMDE prospects since 2012. Disappointing global trade growth has been attributed to a combination of factors, including anemic growth in advanced economies, weak global investment, slowing expansion of global value chains and limited progress on trade liberalization. The sharp drop in commodity prices has been an aggravating factor for commodity exporters (Baffes et al. 2015). From their peak in 2011 to the first quarter of 2016, commodity prices dropped by 33 percent for agriculture products, 53 percent for metals, and 65 percent for energy. As a reflection of these negative terms-of-trade shocks, commodity exporters account for 90 percent of EMDEs experiencing a protracted slowdown in recent years.

Beyond external factors, the slowdown also reflected domestic headwinds, including the unwinding of cyclically strong, policy-supported growth in the post-crisis period, as well as rising supply side constraints, demographic pressures, and lower productivity growth (World Bank 2016b; Didier et al. 2015). Moreover, fiscal and monetary policy space has narrowed, particularly in commodity exporters. Bouts of policy uncertainty and erosion of policy buffers also contributed to dampen confidence and activity. Investor concerns about growth prospects and rising vulnerabilities have been reflected in lower credit ratings, particularly among commodity exporters. Against this backdrop, NIRP is not expected to play a substantial role in boosting capital flows to EMDEs as earlier unconventional monetary policies did in the post-crisis period. 
Figure 18. Growth, sovereign ratings and policy space in EMDEs

\section{A. Growth by group}

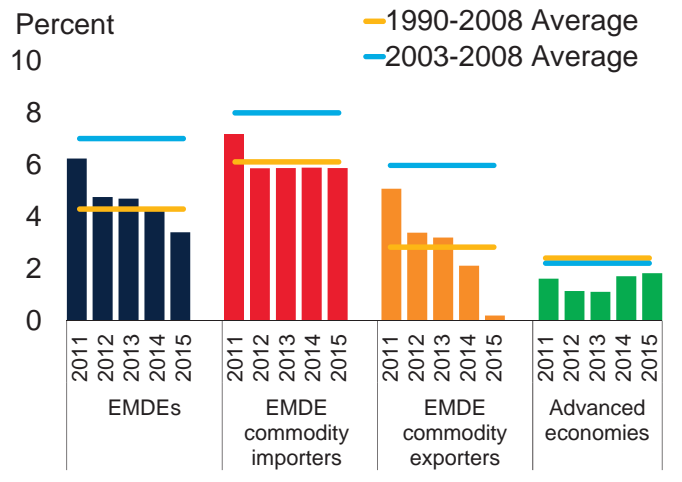

C. Sovereign rating and commodity prices Average sovereign rating Index -Commodity exporters

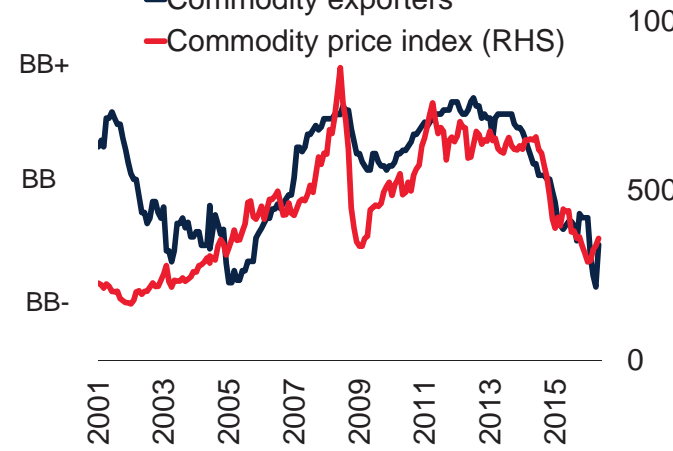

\section{E. 2015 fiscal balances}

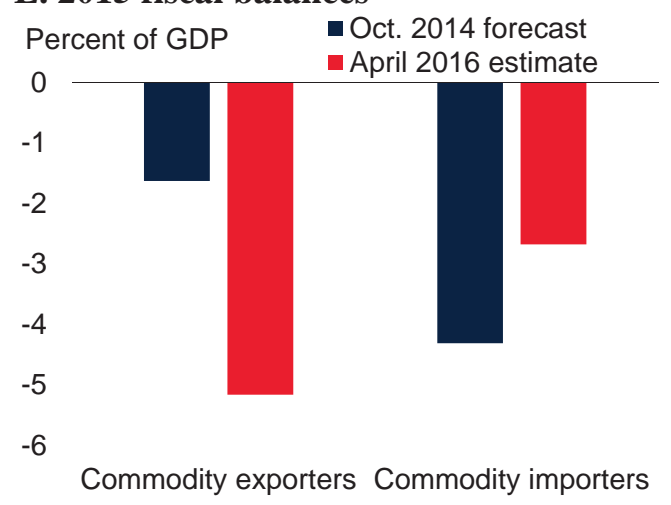

B. Growth Differential between EMDEs and advanced economies

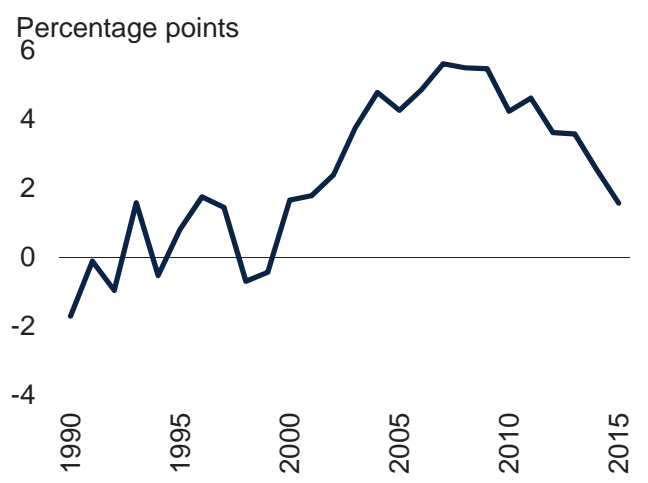

D. Stock of EMDE bonds maturing

Percent of gross bond issuance in 2015

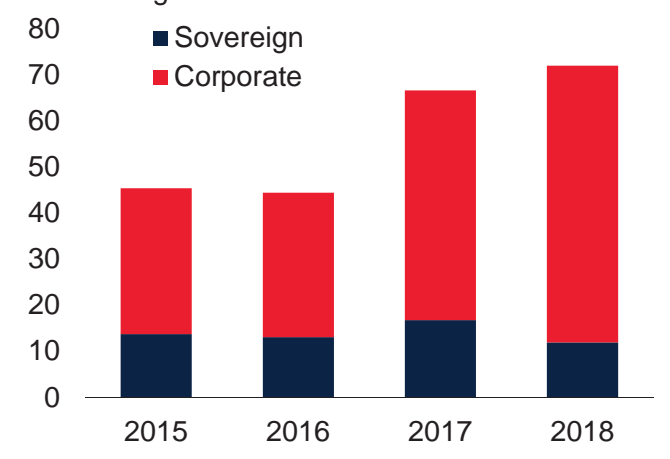

\section{F. Policy interest rates}

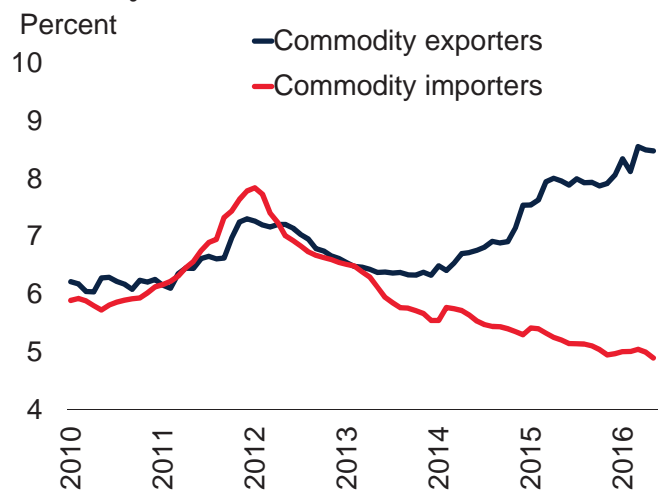

Sources: World Bank, Standard and Poor's, Haver Analytics, EPFR, International Monetary Fund.

C. Sample includes 44 EMDE commodity exporters. Simple average across country group. Last observation is April 2016.

D. Last observation is May 2016.

E. 2015 budget balances as predicted in October 2014 and estimated in April 2016. Simple average across country group.

F. Sample includes 29 commodity exporters and 21 commodity importers. Simple average across country group. Last observation is April 2016. 


\subsection{EMDE financial variables following NIRP announcements: An event study}

The same event study methodology used in section 4.4 is applied in an assessment of the immediate impact of NIRP announcements on financial market developments across EMDEs. Movements in high-frequency indicators on EMDE assets in response to policy changes by BoJ, ECB, and SNB are tracked over time. Isolating the specific effect of NIRP is particularly challenging in an international context, as many more factors come into play, requiring cautious interpretations of the results. Other caveats previously highlighted apply as well.

The approach is comparable to previous studies analyzing the spillover effects of unconventional monetary policies. For instance, Chen et al. (2011) study the spillover effects of QE policies by the U.S. Federal Reserve, BoJ, BoE, and ECB on some EMDEs in Asia and Latin America. They find that earlier asset purchase programs by the U.S. Federal Reserve had larger positive effects on EMDE equity prices and bond spreads, while similar policies by the BoE and ECB led to somewhat mixed results.

On average, the response of EMDE assets is broadly consistent with expectations and previous literature. Currencies appreciated, bond spreads declined, and equity prices increased on the day of the announcement (Figure 19, Table A.3). The average impact on EMDEs is directionally consistent with previous estimates for QE policies by major advanced economies. The reactions of bond spreads, nominal effective exchange rates and equity prices across major emerging markets are of particular interest. Bond spreads declined across the majority of large emerging markets. However, the responses of other emerging markets were rather muted. The positive stockmarket response was broad-based while the exchange rate response varied considerably across countries, both in terms of size and direction. The differences across countries likely reflect domestic developments or other changes in international financial markets on the day of the announcement. If the event window is extended from one day to one month, results show a considerable range of outcomes with no clear pattern, except for a seemingly persistent positive effect on median equity prices (Figure A.4). Mixed results over an extended window likely reflect the influence of a wide range of factors other than just NIRP announcements.

\subsection{What EMDE policy responses are appropriate?}

While NIRP type unconventional policies in some advanced economies could have immediate positive effects on EMDE financial conditions, these can abruptly change due to the impact of these policies on financial stability, suggesting the need for EMDEs to be ready to implement appropriate policy responses, depending on their cyclical positions and available policy room. Favorable borrowing costs thanks to NIRP might help deploy counter-cyclical fiscal policy, if needed, in EMDEs with adequate fiscal space. NIRP also has implications for EMDE monetary, macro-prudential, and capital flow management policies to help mitigate the implications of changes in external financing conditions. 
Figure 19. NIRP announcements: changes in EMDE financial variables over one-day window

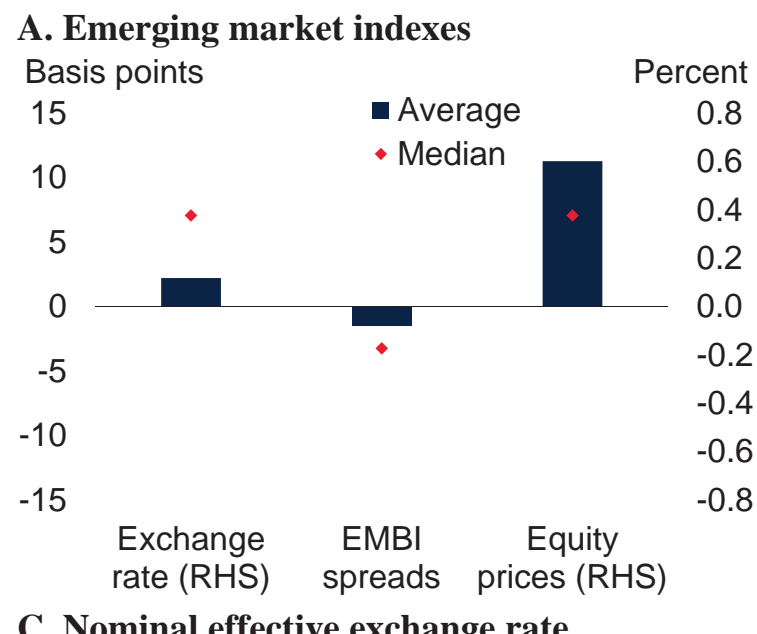

C. Nominal effective exchange rate

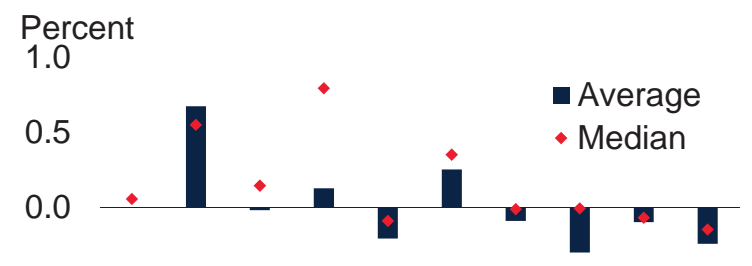

$-0.5$

$-1.0$

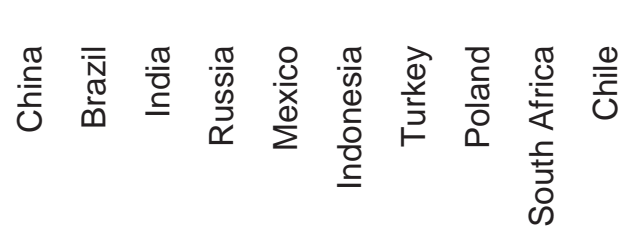

B. 10-year government bond yields

Basis points

15

10

5

Median

- Median

$-5$

$-10$

$-15$

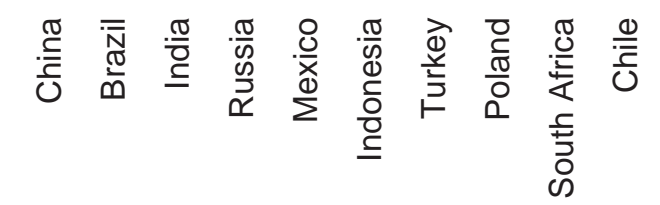

D. Equity market indexes

Percent

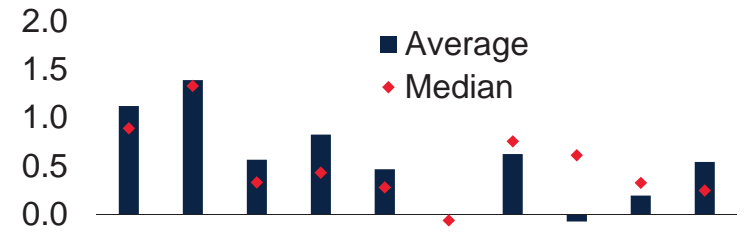

$-0.5$

$-1.0$

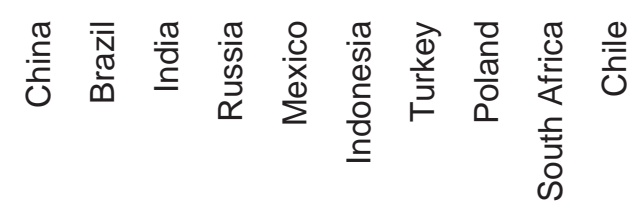

Sources: J.P. Morgan, Bloomberg, Haver Analytics, World Bank.

Notes: Basis points or percent change between closing values on the day before the NIRP announcement and closing values on the day of the announcement. NIRP announcements are those of the European Central Bank, the Bank of Japan, and that coinciding with the Swiss National Bank's decision to abandon the Swiss franc's floor against the euro. For emerging market indexes, exchange rate is the JP Morgan EM Foreign Exchange Index, EMBI spread is calculated as the average premium paid over a U.S. government bond with comparable 10 maturity, and equity prices are the MSCI Emerging and Frontier index.

B. Bond yields are for 10-year government bonds.

C. A decrease indicates depreciation.

D. Equities are the main stock market index for each country, expressed in local currency.

Monetary policy. In some commodity-exporting EMDEs, sharp depreciations and balance sheet vulnerabilities have already increased financial stability risks. Several central banks have responded with pro-cyclical tightening of policy and foreign exchange interventions or controls. Narrowing monetary policy space, especially in commodity exporters, places a premium on credible monetary policy frameworks that maintain price stability over the medium term, and institutional reforms that limit the risk of pro-cyclical policies associated with capital outflows.

Moderate inflation and more stable currencies in commodity-importing EMDEs might allow counter-cyclical monetary policy, but rising interest rates in the United States might eventually 
constrain room for action. In principle, the event studies presented earlier suggest that NIRP in advanced economies should provide some additional room for maneuver for monetary policy in EMDEs due to its generally benign effects on financing conditions, if renewed dollar appreciation pressures are contained.

Fiscal policy. Since the management of capital flows can constrain monetary policy, the availability of fiscal policy as a countercyclical tool becomes particularly important for EMDEs. On the one hand, sustained downward pressure on global interest rates should help contain borrowing costs and create some fiscal space to maneuver, if needed. On the other hand, fiscal policy should lean against temporary capital inflows associated with exceptionally accommodative monetary policies in advanced economies, including NIRP, and rebuild buffers before global financing conditions tighten again.

Although sovereign debt in EMDEs is significantly lower than in the early 2000s, fiscal space generally narrowed as fiscal deficits widened rapidly in the aftermath of the global financial crisis. Several EMDEs need to improve their fiscal positions to regain policy space for effective fiscal stimulus that may be needed when global interest rates start rising again. When a government with narrow space conducts expansionary fiscal policy, rising sovereign credit risks or expectations of higher taxes and lower spending in the future could significantly weaken the effectiveness of the policy (Huidrom, Kose, and Ohnsorge 2016; Huidrom et al. 2016; World Bank 2015b). Countries need to rebuild buffers at a pace appropriate to their specific circumstances, with commodity importers and exporters facing increasingly divergent policy challenges in this regard. Over the medium-term, credible and well-designed institutional arrangements, such as fiscal rules, stabilization funds, and medium-term expenditure frameworks, can help restore space for countercyclical fiscal policy, and strengthen policy outcomes.

Macro-prudential and capital flow management policies. Macro-prudential policies should be employed to mitigate systemic risks and reduce the pro-cyclicality of domestic financial sectors. ${ }^{32}$ Beyond the implementation of counter-cyclical capital buffers under Basel III requirements, macro-prudential frameworks can be reinforced through a range of instruments, including caps on loan-to-value or debt-to-income ratios, dynamic provisioning, and credible stress tests. Banks and non-financial corporates with elevated foreign currency mismatches and/or significant reliance on short-term debt warrant close monitoring (Claessens, Coleman, and Donnelly 2016).

If financial stress threatens financial stability-for example because of large foreign currency liabilities-intervention in foreign currency markets through the use of international reserve or swap market operations may be necessary. The removal of capital inflow restrictions or the imposition of temporary controls on outflows might be justified under certain circumstances, but

\footnotetext{
${ }^{32}$ For instance, using a dynamic equilibrium framework, Arslan, Guler, and Taskin (2015) show that macro-prudential policies help moderate fluctuations in house prices and mortgage default rates. For a broader discussion on the use of macroprudential policies during financial stress episodes, see Claessens et al. (2014).
} 
only as a complement to sound macroeconomic policies, financial supervision and regulation (Arteta et al. 2015).

\section{Conclusion}

A number of central banks, including the DNB, ECB, Riksbank, SNB, BoJ, and MNB, have employed NIRP to provide additional monetary policy stimulus over the past few years. These central banks are now charging (instead of paying) commercial banks for their excess reserves. Countries with short-term policy rates in negative territory now account for one-fourth of world GDP. The global economy has never before witnessed negative interest rates in such a large scale. The unprecedented step of deploying NIRP in multiple countries has not just extended the boundaries of unconventional monetary policies but also added fuel to an already polarized debate about the implications of these policies.

However, there has been only limited research on NIRP to inform this debate. This paper presents a comprehensive analysis of the implications of NIRP by exploring the reasons behind the implementation of these policies and by examining their domestic and international implications. This concluding section briefly answers the five questions posed at the beginning of the paper. It also discusses the next possible frontier for monetary policy and the need for a broader set of policies to promote growth and price stability in light of recent debates on these issues, and suggests directions for future research.

Why are some monetary policy rates negative? In a context of continued growth disappointments, depressed inflation expectations, and declining real equilibrium interest rates, the aforementioned central banks introduced NIPR to provide additional monetary policy accommodation. NIRP aimed to show central banks' resolve to meet their policy objectives, as the perceived zero lower bound constrained their ability to commit to additional policy easing. In particular, the main motivation for the implementation of NIRP by the ECB, BoJ, Riksbank, and MNB was the need to stabilize inflation expectations and support growth. In the case of the SNB and DNB, an immediate motivation was the need to respond to currency appreciation and capital inflow pressures. For central banks implementing quantitative easing (QE) policies, possibly two additional considerations were the narrowing pool of assets eligible for their purchase programs and the possibility of diminishing returns from QE.

How do the transmission channels of monetary policy operate under NIRP? Monetary transmission channels in the presence of NIRP are conceptually analogous to those at work under conventional monetary policy. Specifically, NIRP are expected to be transmitted mainly through the interest rate, credit, portfolio, and exchange rate channels. However, under NIRP, there are complications associated with these channels that could limit policy effectiveness, particularly if they have adverse effects on the financial sector. For example, in the case of the interest rate channel, banks may hesitate to impose negative rates on depositors in order to prevent a widespread shift to cash hoarding. This tendency may either limit the pass-through to lending rates, as banks 
seek to maintain interest margins, or negatively affect profitability, which could eventually weaken the transmission of monetary policy.

How have key financial variables evolved since the introduction of NIRP? Key financial variables have moved as implied by the standard transmission channels of monetary policy. For example, policy rate cuts to negative levels have been generally reflected in corresponding declines in money market rates and short-term government bond yields. The fall in bank wholesale funding costs has helped lower lending rates to varying degrees across countries. The decline in rates on new loans has been particularly notable in the euro area, although other policy initiatives make the specific contribution of NIRP difficult to isolate. The pass-through in other countries has been more limited. Inflation expectations have continued to decline in most NIRP economies. Currencies of countries implementing NIRP have on average depreciated since the corresponding policy decisions, with the exception of the appreciation of the Japanese yen and Swiss franc.

An event study indicates that money market rates and sovereign bond yields fall on the day of NIRP announcements, whereas inflation expectations do not change much and currency movements vary across countries. For the euro area, a comparison of the responses of key financial variables to announcements of NIRP, QE, and conventional interest rate cuts shows that the responses following NIRP are directionally consistent to those of conventional cuts, although somewhat smaller. Overall, despite its potential drawbacks, NIRP appear to have helped deliver additional monetary stimulus in a challenging macroeconomic environment.

How could NIRP affect financial stability? NIRP could pose risks to financial stability, particularly if rates go substantially below zero or if NIRP are employed for a protracted period of time. Adverse outcomes could include the erosion of profitability of banks and other financial intermediaries, and excessive risk taking. Available data so far provides inconclusive evidence of significant impact of NIRP on bank profitability. While some bank surveys indicate a perception among survey participants that NIRP are having an adverse impact on banks' net income, bank lending margins remain within post-crisis ranges and credit growth has improved, albeit sluggishly in most cases. An event study also shows that the initial reaction of bank equity prices to NIRP announcements has been muted in most cases, while financial sector CDS spreads have generally declined on the announcement day.

Most central banks have introduced complementary policy measures to mitigate the potentially negative impact of NIRP on bank profitability. For example, in the case of the ECB, the implementation of NIRP was part of a package of measures including exceptionally favorable refinancing conditions for banks as well as expanded asset purchases. The BOJ, Riksbank, DNB, and SNB also implemented additional measures to alleviate pressure on bank earnings stemming from NIRP.

With the rising share of negative-yielding debt securities, pension and life insurance companies could struggle to generate adequate returns to meet their long-term liabilities. NIRP, as other unconventional monetary policies, could also encourage excessive risk-taking, which could 
contribute over time to the formation of asset price bubbles. However, increases in house and equity prices have thus far remained moderate in most NIRP economies.

NIRP raise the question of how low negative rates can go before market distortions become significant enough to threaten financial stability. At the extreme, if central banks pushed policy rates too far into negative territory, there is a risk that large sectors of the economy could become cash-based. While some central banks have reduced their policy rates below -0.5 percent without any easily discernible financial market distortions, it is unclear whether rates could go much lower, or for a prolonged period, without raising financial stability concerns.

What are the implications of NIRP for emerging market and developing countries (EMDEs)? As the United States embarks on a gradual normalization of monetary policy, accommodative monetary policies, including NIRP, by other major central banks could help contain the ensuing increase in global interest rates and support demand for riskier, higher-yielding assets, including those of EMDEs. An event study shows that the responses of EMDE assets to NIRP announcements is on average broadly consistent with expectations: currencies of EMDEs appreciated, bond spreads declined, and equity prices increased on the day of the announcement. The average impact on EMDEs is also directionally consistent with previous estimates for QE policies by major central banks. While NIRP, as other unconventional monetary policies in major advanced economies, could have immediate positive effects on EMDE financial conditions, financial stability risks could combine with domestic vulnerabilities and lead to disruptions in capital inflows to EMDEs. EMDEs should rebuild the necessary policy buffers and implement policies to be able to effectively mitigate the impact of volatile capital flows.

What is the next frontier for monetary policy? Against the background of diminished long-term expectations for growth and inflation throughout the world economy (Figure 20), the introduction of NIRP has led to a vigorous debate about the next frontier for unconventional monetary policies. Reaching the effective floor of NIRP might not necessarily signal the limit of unconventional monetary policy experimentations. Expanding the size and coverage of asset purchase programs, setting higher inflation targets, targeting price levels instead of inflation, and transitioning into digital money or imposing a tax on money to eliminate the zero lower bound are other alternative tools that have been discussed recently. ${ }^{33}$

\footnotetext{
${ }^{33}$ Buiter (2014), Bernanke (2016), Citi (2016c), Deutsche Bank (2016b), and Morgan Stanley (2016b) present more detailed discussions of the "helicopter money". The feasibility of a tax on money has also been subject to debate in academic circles as a way to overcome the zero bound on interest rates (Goodfriend 2000 and 2002; Buiter and Panigirtzoglou 2003; Ilgmann and Menner 2011). Some studies also analyze the costs and benefits of phasing out paper currency as one way to eliminate the zero bound in interest rates (Agarwal and Kimball 2015). Rogoff (2014), for instance, suggests that the phasing-out procedure could begin with large-denomination notes, extended to others except small coins and bills, and finally abolishing the smallest ones. Buiter (2009) also argues that issuing only small notes such as 5 dollar bills would increase the cost of holding cash sufficiently to shift the effective lower bound to a deeper negative value.
} 
Figure 20. Long-term growth and inflation forecasts
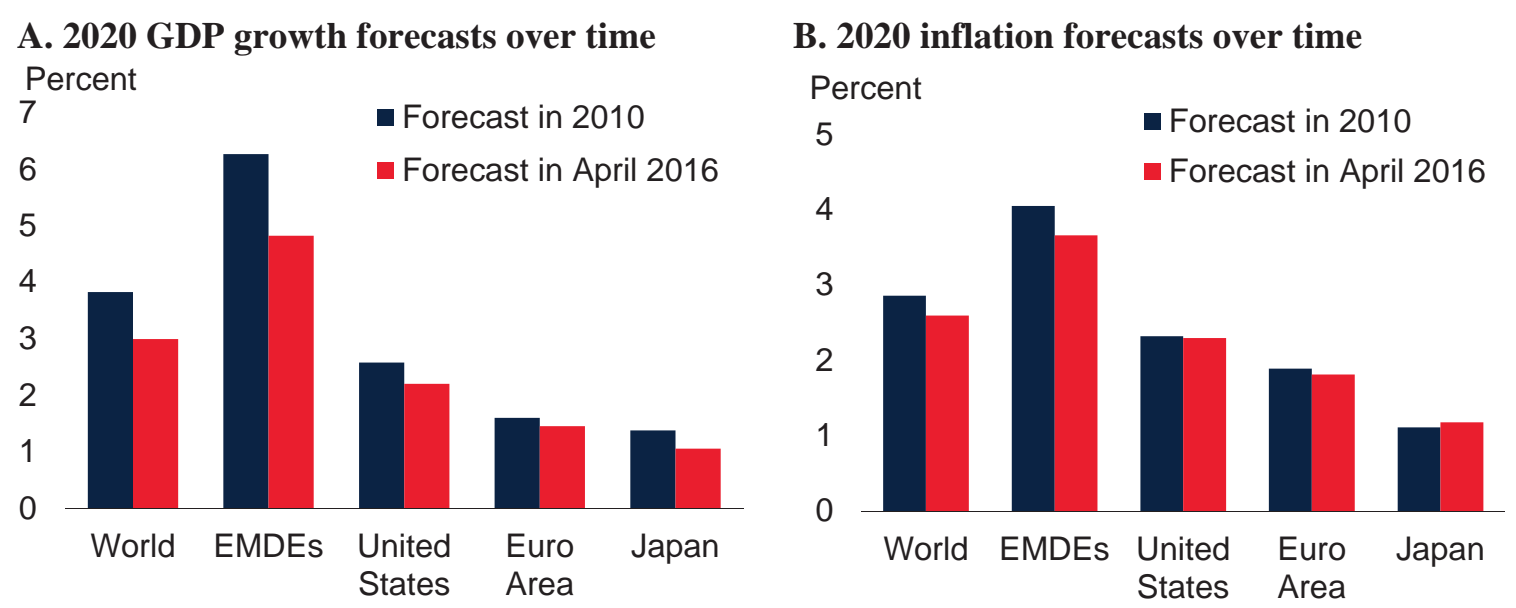

Sources: Consensus Economics, World Bank.

Notes: A: GDP-weighted average growth rates for World and EMDEs (emerging market and developing economies). The World aggregate is based on 45 countries for which long-term consensus forecast data are available. EMDEs consist of 22 economies.

B: GDP-weighted average CPI inflation rates for World and EMDEs. From these two aggregate groups, Venezuela, RB, is excluded due to high inflation forecast.

An additional and perhaps more controversial step might involve so-called "helicopter money," a concept initially floated by Friedman (1969). The practical implementation of such a policy was first suggested by Bernanke (2002) to address persistent deflation in Japan. The idea is to stimulate aggregate demand by increasing public spending and/or cutting taxes through monetary financing. The implementation of such policy might involve infrastructure spending or direct tax rebates to households financed through an increase in money supply. The growth in aggregate demand, all else being equal, could eventually inflate prices. However, more work on the logistical aspects and implications of these types of policies is necessary before their implementation.

Why is a broader mix of policies needed? The benefits of unconventional monetary policy might diminish over time, and the risks associated with their aggressive use point to the need for a broader mix of macroeconomic policies (Kose and Terrones 2015; World Bank 2016b). Specifically, monetary policy should be complemented by fiscal and structural policies that could support aggregate demand and help counter adverse shocks in the future (Cœuré 2016). Moreover, in a context of ultra-low interest rates and borrowing costs, and given the secular decline in public investment in many advanced economies, there is increased room for a mix of spending measures and tax reforms. The positive returns on public investment and the possible crowding in of private investment in infrastructure, education, and health make a case for a significant reorientation of public expenditure in that direction (IMF 2014; World Bank 2016a; Ball, De Long, and Summers 2014). 
What are the main issues for future research? The persistent need to use unconventional monetary policy amid sluggish global growth and very low inflation calls for additional research on NIRP in many frontiers. First, there is very little evidence on the macroeconomic and financial effects of NIRP. Once sufficiently long time series are available, future empirical research could examine these effects and conduct counterfactual analysis to disentangle the contribution of NIRP to activity and financial market developments. ${ }^{34}$ Alternatively, a general equilibrium framework could be employed through a monetary DSGE model with a relaxed zero lower bound assumption. That approach would be useful in understanding the channels of monetary policy transmission and welfare implications in a NIRP environment. ${ }^{35} \mathrm{~A}$ similar approach could be used to study spillover implications of NIRP within a multi-country DSGE framework. ${ }^{36}$

Second, it would be useful to compare the effects of NIRP with those of cuts in low and positive territory and of QE policies. Third, there is a need for further exploration of the determinants of cross-border lending activity by banks to better assess the global implications of NIRP. Fourth, it would be useful to provide empirical evidence about the impact of NIRP on the profitability of banks and non-bank financial institutions. Finally, the effective lower bound for policy rates-a crucial element for policy design—remains uncertain and deserves further investigation.

Securing benefits and mitigating risks. In an environment of weak growth, depressed real interest rates and inflation expectations, NIRP can help provide additional monetary policy stimulus, as long as policy interest rates are only modestly negative and they do not stay negative for too long as to avoid adverse effects on the financial sector. As such, these policies have a place in a policy maker's toolkit but they need to be handled with care to secure their benefits while mitigating risks.

\footnotetext{
${ }^{34}$ A number of recent papers study the impact of QE policies on inflation and output. Gombacorta, Hofmann, and Peersman (2014), Baumeister and Benati (2013), Kapetanios et al. (2012), and Weale and Wieladek (2016) employ different types of VAR models and document that QE policies had a positive impact on growth and inflation.

${ }^{35}$ In the context of a monetary DSGE model allowing for negative interest rates, Rognlie (2015) argues that using negative interest rates as a policy tool is most useful when cash demand is relatively inelastic and that NIRP could help lower the optimal long-run inflation target.

${ }^{36}$ For example, Dedola et al. (2013) and Gieck (2014) employ two-country DSGE models to study cross-border implications of unconventional monetary policies.
} 
Annexes:

Table A.1. Summary of the literature on the impact of QE policies

\begin{tabular}{|c|c|c|c|c|c|c|}
\hline Long term bond yields (bps) & Fed1 & Fed2 & Fed3 & BoE & ECB & Riksbank \\
\hline Bauer and Neely 2014 & -30.7 & -7.6 & -7.2 & & & \\
\hline Khrisnamurty and Vissing Jorgensen 2011 & -21.4 & -1.8 & & & & \\
\hline Gagnon et al 2010 & -11.4 & & & & & \\
\hline Glick and Leduc 2012 & -20.0 & 0.2 & & -9.8 & & \\
\hline Altavilla et al 2015 & & & & & -29.0 & \\
\hline \multicolumn{7}{|l|}{ Fukugana et al 2015} \\
\hline De Rezende et al 2015 & & & & & & -7.0 \\
\hline Georgiadis and Grab 2015 & & & & & -7.0 & \\
\hline \multicolumn{7}{|l|}{ Short term bond yields (bps) } \\
\hline Bauer and Neely 2014 & -10.7 & -2.3 & -2.2 & & & \\
\hline Khrisnamurty and Vissing Jorgensen 2011 & -5.0 & -0.2 & & & & \\
\hline Gagnon et al 2010 & -4.3 & & & & & \\
\hline Altavilla et al 2015 & & & & & -30.0 & \\
\hline De Rezende et al 2015 & & & & & & -7.0 \\
\hline \multicolumn{7}{|l|}{ Long-term inflation expectations (bps) } \\
\hline Khrisnamurty and Vissing Jorgensen 2011 & 19.0 & 1.0 & & & & \\
\hline Gagnon et al 2010 & -12.6 & & & & & \\
\hline Georgiadis and Grab 2015 & & & & & 8.0 & \\
\hline \multicolumn{7}{|l|}{ Currency markets (percent) } \\
\hline Glick and Leduc 2012 & -1.2 & -0.6 & & -0.7 & & \\
\hline Georgiadis and Grab 2015 & & & & & -1.8 & \\
\hline De Rezende et al 2015 & & & & & & -0.8 \\
\hline
\end{tabular}

Notes: This table summarizes the results of event studies analyzing domestic effects of QE policies. Fed1, Fed2, and Fed3 represent the three successive asset purchase programs undertaken by the US Federal Reserve. The event dates vary depending on the study (see the corresponding papers for detailed descriptions of events). Long term bond yield is the yield on the 10-year benchmark government debt securities. Short term bond yield is the yield on 1, 2, or 3-year government debt, depending on the study. Long term inflation expectations are 10-year inflation swap rates. Currency market reflects either nominal effective exchange rate, or bilateral exchange rate against USD or EUR, depending on the study. The reported numbers represent changes within one-day/two-day event windows or estimated coefficient of event dummy variables in regressions, depending on the study. 
Figure A.1. NIRP announcements: changes in selected financial variables up to one month

\section{A. 2-year government bond yields}

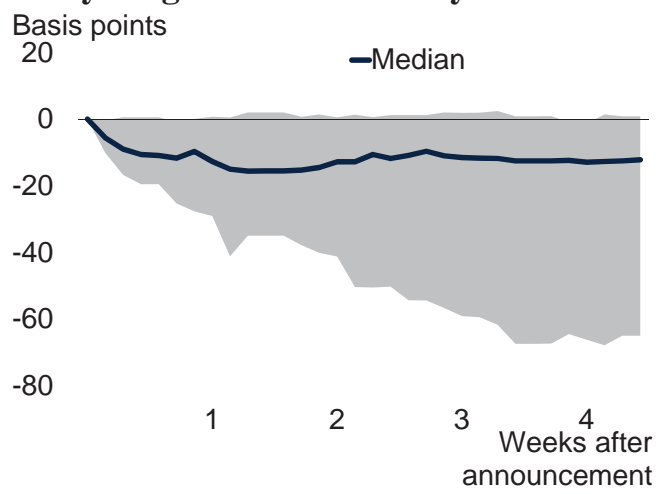

\section{Nominal effective exchange rates}

\section{Percent}

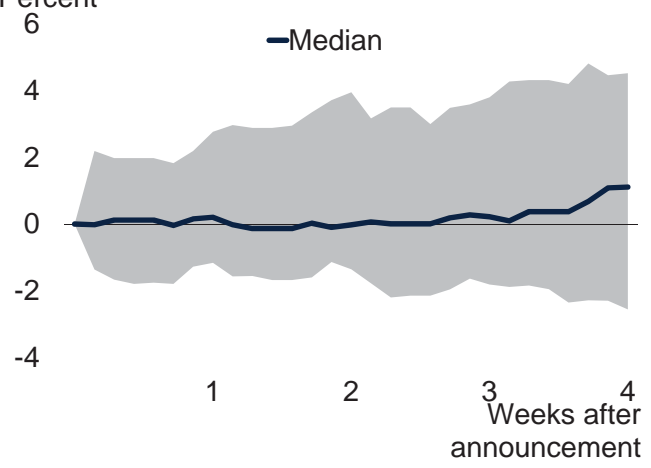

\section{B. 10-year government bond yields} Basis points

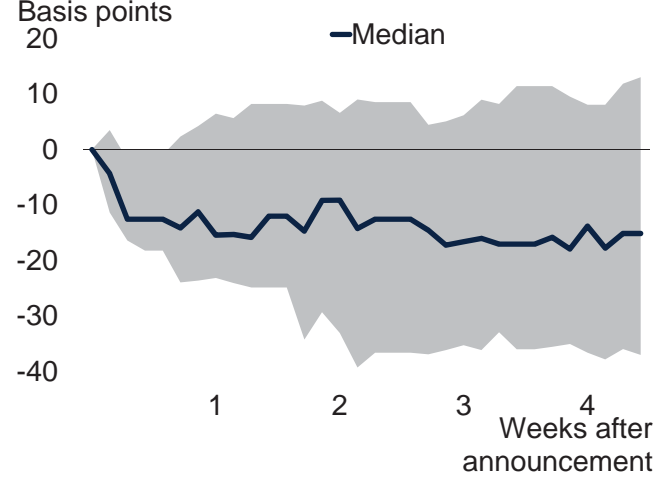

\section{Equities}

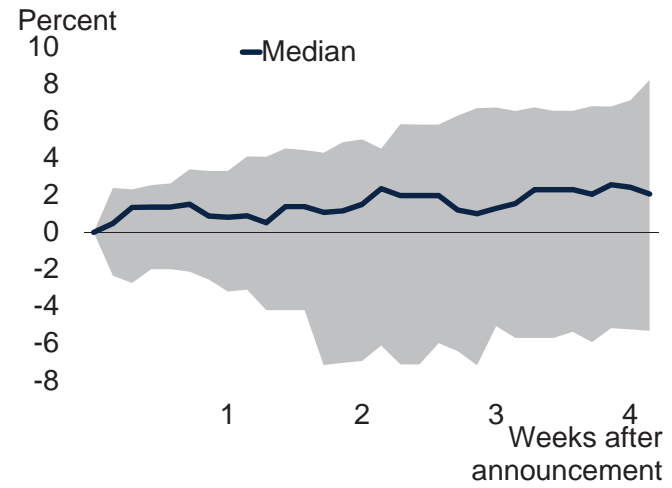

Sources: J.P. Morgan, Bloomberg, Haver Analytics, European Central Bank, World Bank.

Notes: Basis points or percent change from closing values on the day before the NIRP announcement. Line indicates median across 17 NIRP announcements. Grey area indicates $10^{\text {th }}$ and $90^{\text {th }}$ percentile range. Each event is extended out for 30 calendar days. Variable definitions and events are the same as in Figure 9.

C. A decrease in the nominal effective exchange rate indicates depreciation. 
Figure A.2. NIRP announcements: country-specific changes in selected financial variables over one-day window

\section{A. Interest rates and bond yields}

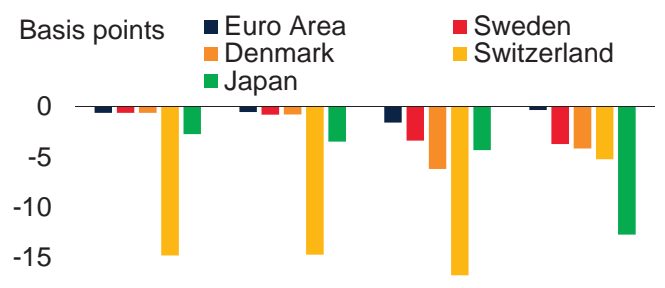

$-20$

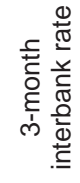

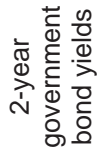

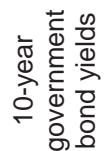

B. Inflation expectations, exchange rates, and equities

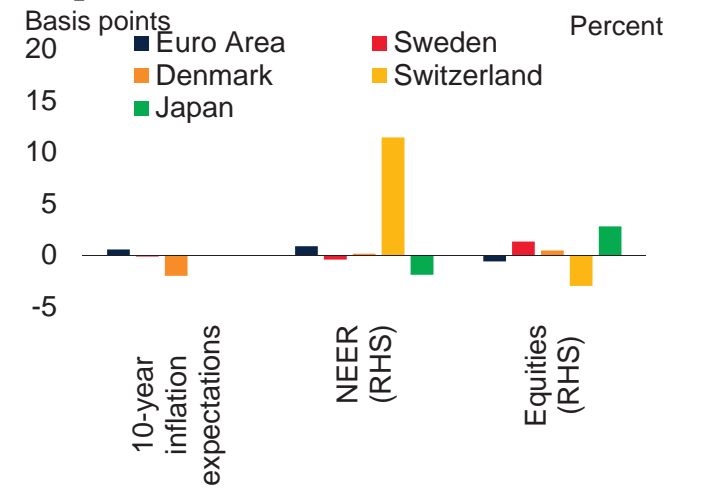

Sources: Bloomberg, Haver Analytics, World Bank.

Notes: Basis points or percent change between closing values on the day before the NIRP announcement and closing values on the day of the announcement. NIRP announcements are: four events for the European Central Bank, one for the Bank of Japan, two for the Swiss National Bank, four for the Swedish Riksbank, and six for Danmarks Nationalbank. Variable definitions are the same as in Figure 9. 
Table A.2. NIRP announcements: country-specific changes in selected financial variables over one-day window

\begin{tabular}{|c|c|c|c|c|c|c|c|c|c|}
\hline Central Bank (policy rate) & Date & Rate & $\begin{array}{l}\text { 1-month } \\
\text { interbank } \\
\text { rate }\end{array}$ & $\begin{array}{l}\text { 3-month } \\
\text { interbank } \\
\text { rate }\end{array}$ & $\begin{array}{l}\text { 2-year } \\
\text { government } \\
\text { bond yields }\end{array}$ & $\begin{array}{l}10 \text { year } \\
\text { government } \\
\text { bond yields }\end{array}$ & $\begin{array}{l}10 \text {-year } \\
\text { inflation } \\
\text { expectations }\end{array}$ & $\begin{array}{l}\text { Nominal } \\
\text { effective } \\
\text { exchange } \\
\text { s rate }\end{array}$ & Equities \\
\hline European Central Bank & June-2014 & -0.10 & -1.1 & -0.9 & -8.3 & -1.2 & 1.5 & 0.5 & 0.9 \\
\hline \multirow[t]{6}{*}{ (Overnight deposit facility rate) } & September-2014 & -0.20 & -0.2 & -0.1 & -6.7 & -7.3 & 2.7 & -1.6 & 1.8 \\
\hline & December-2015 & -0.30 & -0.7 & -0.6 & 9.2 & 13.7 & -3.3 & 3.1 & -3.6 \\
\hline & March-2016 & -0.40 & -0.4 & -0.5 & -0.3 & -6.3 & 1.3 & 1.6 & -1.5 \\
\hline & Total & & -2.4 & -2.1 & -6.2 & -1.2 & 2.2 & 3.6 & -2.4 \\
\hline & Average & & -0.6 & -0.5 & -1.5 & -0.3 & 0.6 & 0.9 & -0.6 \\
\hline & Median & & -0.6 & -0.6 & -3.5 & -3.8 & 1.4 & 1.0 & -0.3 \\
\hline Sveriges Riksbank & February-2015 & -0.10 & -0.5 & -0.1 & -2.2 & -2.8 & 1.5 & -0.7 & -0.6 \\
\hline \multirow[t]{6}{*}{ (One week repo rate) } & March-2015 & -0.25 & -0.6 & -1.3 & -9.6 & -16.5 & -5.0 & -1.2 & 1.7 \\
\hline & July-2015 & -0.35 & -1.2 & -0.6 & -1.3 & 6.1 & 3.0 & -0.3 & 2.2 \\
\hline & February-2016 & -0.50 & -0.1 & -1.1 & -0.3 & -1.6 & 0.0 & 0.5 & 2.1 \\
\hline & Total & & -2.4 & -3.1 & -13.4 & -14.8 & -0.5 & -1.7 & 5.3 \\
\hline & Average & & -0.6 & -0.8 & -3.4 & -3.7 & -0.1 & -0.4 & 1.3 \\
\hline & Median & & -0.6 & -0.9 & -1.8 & -2.2 & 0.8 & -0.5 & 1.9 \\
\hline Danmarks Nationalbank & July-2012 & -0.20 & -0.5 & -0.5 & -6.1 & -7.3 & * & 0.3 & 0.5 \\
\hline \multirow[t]{8}{*}{ (One week certificate of deposit rate) } & September-2014 & -0.05 & 0.3 & -0.5 & -5.6 & 1.8 & 2.0 & 0.7 & 0.3 \\
\hline & January-2015 & -0.20 & -2.3 & -2.0 & -9.9 & -6.8 & -2.0 & -0.9 & 2.0 \\
\hline & January-2015 & -0.35 & 0.3 & 0.3 & -2.9 & -6.7 & 3.0 & 1.5 & 0.2 \\
\hline & January-2015 & -0.50 & -0.8 & -1.0 & -2.3 & -1.5 & -13.0 & 0.0 & -0.2 \\
\hline & February-2015 & -0.75 & -0.5 & -0.8 & -10.3 & -4.3 & 0.0 & -0.7 & 0.0 \\
\hline & Total & & -3.5 & -4.5 & -37.1 & -24.8 & -10.0 & 0.9 & 2.8 \\
\hline & Average & & -0.6 & -0.8 & -6.2 & -4.1 & -2.0 & 0.1 & 0.5 \\
\hline & Median & & -0.5 & -0.6 & -5.9 & -5.5 & 0.0 & 0.1 & 0.2 \\
\hline Swiss National Bank & December-2014 & -0.25 & -2.1 & -5.0 & -7.3 & 0.0 & * & -0.2 & 2.7 \\
\hline \multirow[t]{4}{*}{ (Overnight sight deposit rate) } & January-2015 & -0.75 & -27.5 & -24.4 & -26.2 & -10.4 & * & 23.1 & -8.7 \\
\hline & Total & & -29.6 & -29.4 & -33.5 & -10.4 & * & 22.9 & -6.0 \\
\hline & Average & & -14.8 & -14.7 & -16.8 & -5.2 & * & 11.4 & -3.0 \\
\hline & Median & & -14.8 & -14.7 & -16.8 & -5.2 & * & 11.4 & -3.0 \\
\hline $\begin{array}{l}\text { Bank of Japan } \\
\text { (Current account deposit rate) }\end{array}$ & January-2016 & -0.10 & -2.7 & -3.4 & -4.3 & -12.7 & 0.0 & -1.9 & 2.8 \\
\hline
\end{tabular}

Sources: Bloomberg, Haver Analytics, European Central Bank, Riksbank, Danmarks Nationalbank, Swiss National Bank, Bank of Japan, Central Bank of Hungary, and World Bank.

Notes: "Rate" refers to the main deposit policy rate in most cases, and the main refinancing rate for the Riksbank. Basis points or percent change between closing values on the day before the NIRP announcement and closing values on the day of the announcement. Variable definitions are the same as in Figure 9 . The interes rates and inflation expectations are expressed in basis points, while the exchange rate and equities are in percent. 
Figure A.3. NIRP announcements: changes in financial sector variables up to one month

\section{A. Financial sector CDS}

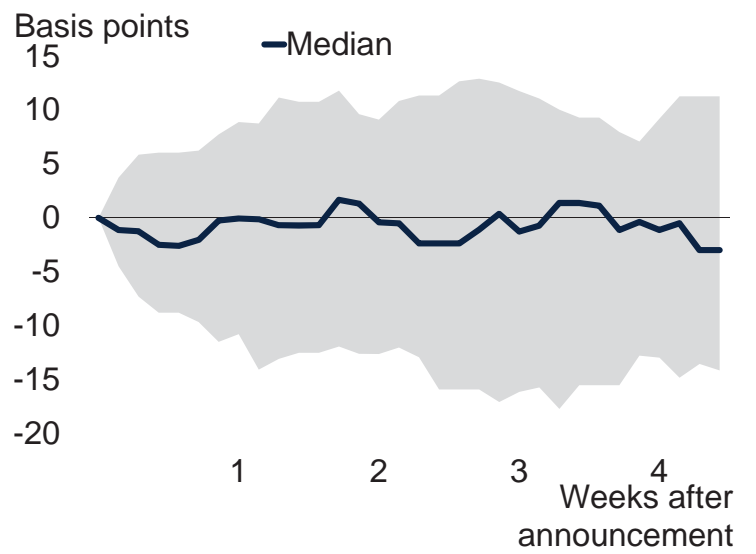

\section{B. Financial sector equities}

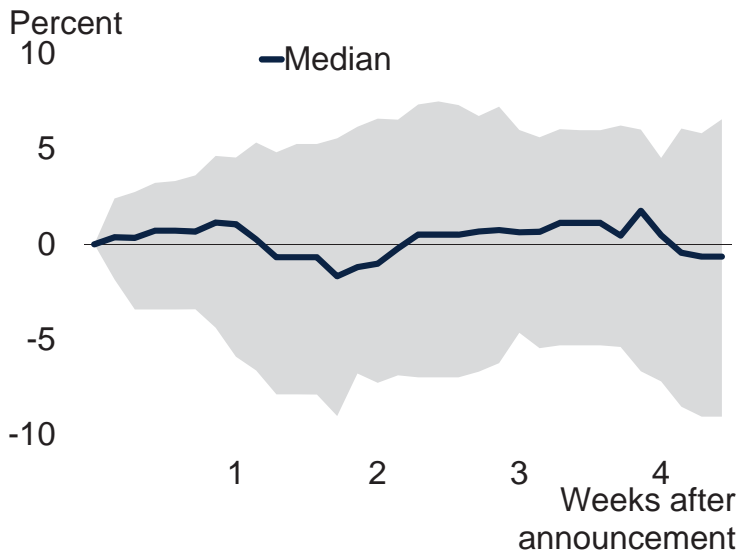

Sources: Bloomberg, World Bank.

Notes: Basis points or percent change from closing values on the day before the NIRP announcement. Line indicates median across 17 NIRP announcements. Grey area indicates $10^{\text {th }}$ and $90^{\text {th }}$ percentile range. Each event is extended out for 30 calendar days. Financial sector CDS is, for all the events caused by central banks in Europe, a Europe-wide senior bank debt CDS index, and, analogously for Japan. Financial sector equities are the broad financial sector index for each nation or area. 
Table A.3. NIRP announcements: changes in EMDE financial variables over one-day window

\section{A. Emerging market aggregates}

\begin{tabular}{|c|c|c|c|c|c|}
\hline Central Bank (policy rate) & Date & Rate & $\mathrm{FX}$ & $\begin{array}{l}\text { Bond } \\
\text { spreads }\end{array}$ & Equities \\
\hline European Central Bank & June-2014 & -0.10 & 0.5 & -3.4 & 0.4 \\
\hline \multirow[t]{4}{*}{ (Overnight deposit facility rate) } & September-2014 & -0.20 & -0.4 & -4.7 & -0.1 \\
\hline & December-2015 & -0.30 & 0.5 & -3.1 & -0.3 \\
\hline & March-2016 & -0.40 & 0.3 & -4.1 & 0.4 \\
\hline & Total & & 0.9 & -15.3 & 0.4 \\
\hline $\begin{array}{l}\text { Swiss National Bank } \\
\text { (Overnight sight deposit rate) }\end{array}$ & January-2015 & -0.75 & -0.7 & 3.1 & 0.4 \\
\hline \multirow[t]{3}{*}{$\begin{array}{l}\text { Bank of Japan } \\
\text { (Current account deposit rate) }\end{array}$} & January-2016 & -0.10 & 0.5 & 3.3 & 2.8 \\
\hline & Average & & 0.1 & -1.5 & 0.6 \\
\hline & Median & & 0.4 & -3.2 & 0.4 \\
\hline
\end{tabular}

\section{B. 10-year government bond yields (basis points)}

\begin{tabular}{|c|c|c|c|c|c|c|c|c|c|c|c|c|}
\hline Central Bank (policy rate) & Date & Rate & China & Brazil & India & Russia & Mexico & Indonesia & Turkey & Poland & $\begin{array}{l}\text { South } \\
\text { Africa }\end{array}$ & Chile \\
\hline European Central Bank & June-2014 & -0.10 & 7.0 & -10.8 & 3.7 & -10.0 & 2.3 & 0.1 & -24.8 & -3.3 & -4.0 & -1.0 \\
\hline \multirow[t]{4}{*}{ (Overnight deposit facility rate) } & September-2014 & -0.20 & 3.0 & 20.3 & 2.3 & 1.0 & -0.1 & -7.0 & -4.1 & 0.5 & -11.0 & 8.0 \\
\hline & December-2015 & -0.30 & -2.0 & 1.5 & -3.8 & 9.0 & 8.5 & 2.3 & 9.8 & 15.7 & 0.0 & 0.0 \\
\hline & March-2016 & -0.40 & -9.6 & 0.3 & -1.8 & 3.5 & 0.3 & -3.0 & -8.6 & 0.6 & -15.0 & 0.0 \\
\hline & Total & & -1.6 & 11.3 & 0.5 & 3.5 & 10.9 & -7.6 & -27.7 & 13.5 & -30.0 & 7.0 \\
\hline $\begin{array}{l}\text { Swiss National Bank } \\
\text { (Overnight sight deposit rate) }\end{array}$ & January-2015 & -0.75 & 0.0 & -0.4 & -11.0 & 0.0 & -5.8 & -3.6 & 2.3 & -9.0 & -8.0 & -4.0 \\
\hline \multirow[t]{3}{*}{$\begin{array}{l}\text { Bank of Japan } \\
\text { (Current account deposit rate) }\end{array}$} & January-2016 & -0.10 & -6.0 & -20.1 & -3.8 & 3.5 & -5.4 & -18.1 & -8.3 & -4.5 & -22.0 & -8.0 \\
\hline & Average & & -1.3 & -1.5 & -2.4 & 1.2 & -0.1 & -4.9 & -5.6 & 0.0 & -10.0 & -0.8 \\
\hline & Median & & -1.0 & 0.0 & -2.8 & 2.3 & 0.1 & -3.3 & -6.2 & -1.4 & -9.5 & -0.5 \\
\hline
\end{tabular}

C. Nominal effective exchange rate (percent)

\begin{tabular}{|c|c|c|c|c|c|c|c|c|c|c|c|c|}
\hline Central Bank (policy rate) & Date & Rate & China & Brazil & India & Russia & Mexico & Indonesia & Turkey & Poland & $\begin{array}{l}\text { South } \\
\text { Africa }\end{array}$ & Chile \\
\hline European Central Bank & June-2014 & -0.10 & -0.3 & 0.9 & 0.0 & 0.8 & 0.5 & 0.2 & 1.0 & -0.1 & 0.5 & 0.2 \\
\hline \multirow[t]{4}{*}{ (Overnight deposit facility rate) } & September-2014 & -0.20 & 0.5 & 0.1 & 0.6 & 0.8 & 0.0 & 0.3 & 0.6 & -0.4 & 0.3 & -0.3 \\
\hline & December-2015 & -0.30 & -0.8 & 1.5 & -1.3 & -3.3 & -1.2 & -0.9 & -1.6 & 0.2 & -1.1 & -0.4 \\
\hline & March-2016 & -0.40 & -0.1 & 0.2 & -0.5 & -1.3 & -1.1 & 0.4 & -0.9 & 0.1 & -1.9 & -1.1 \\
\hline & Total & & -0.7 & 2.7 & -1.0 & -3.1 & -1.8 & 0.0 & -0.9 & -0.2 & -2.2 & -1.6 \\
\hline $\begin{array}{l}\text { Swiss National Bank } \\
\text { (Overnight sight deposit rate) }\end{array}$ & January-2015 & -0.75 & 0.3 & -0.5 & 0.2 & 1.8 & -0.2 & 0.4 & -0.6 & -2.3 & -0.5 & 0.1 \\
\hline \multicolumn{13}{|l|}{ (Current account deposit rate) } \\
\hline & Average & & 0.0 & 0.7 & 0.0 & 0.1 & -0.2 & 0.3 & -0.1 & -0.3 & -0.1 & -0.2 \\
\hline & Median & & 0.1 & 0.6 & 0.1 & 0.8 & -0.1 & 0.4 & 0.0 & 0.0 & -0.1 & -0.1 \\
\hline \multicolumn{13}{|c|}{ D. Equity prices (percent) } \\
\hline Central Bank (policy rate) & Date & Rate & China & Brazil & India & Russia & Mexico & Indonesia & Turkey & Poland & Africa & Chile \\
\hline European Central Bank & June-2014 & -0.10 & 1.0 & -0.5 & 0.9 & 0.7 & 0.5 & 0.1 & 1.8 & 0.8 & 0.1 & 0.5 \\
\hline \multirow[t]{4}{*}{ (Overnight deposit facility rate) } & September-2014 & -0.20 & 0.7 & -1.7 & -0.2 & 0.2 & 0.6 & -0.4 & 1.1 & 1.0 & 0.6 & -0.1 \\
\hline & December-2015 & -0.30 & 0.7 & 3.3 & -0.9 & -0.8 & -0.9 & -0.2 & -1.2 & -1.0 & -1.4 & 0.0 \\
\hline & March-2016 & -0.40 & -1.9 & 1.9 & -0.7 & -0.2 & -0.3 & -0.4 & 0.4 & 0.5 & 0.1 & 0.6 \\
\hline & Total & & 0.6 & 2.9 & -0.9 & -0.1 & -0.1 & -0.9 & 2.1 & 1.2 & -0.7 & 0.9 \\
\hline $\begin{array}{l}\text { Swiss National Bank } \\
\text { (Overnight sight deposit rate) }\end{array}$ & January-2015 & -0.75 & 2.9 & 0.8 & 2.7 & 2.6 & 0.0 & 0.6 & 0.2 & -3.1 & 1.0 & -0.4 \\
\hline \multirow[t]{3}{*}{$\begin{array}{l}\text { Bank of Japan } \\
\text { (Current account deposit rate) }\end{array}$} & January-2016 & -0.10 & 3.2 & 4.6 & 1.6 & 2.5 & 2.9 & 0.3 & 1.5 & 1.4 & 0.9 & 2.7 \\
\hline & Average & & 1.1 & 1.4 & 0.6 & 0.8 & 0.5 & 0.0 & 0.6 & -0.1 & 0.2 & 0.5 \\
\hline & Median & & 0.9 & 1.3 & 0.3 & 0.4 & 0.3 & -0.1 & 0.8 & 0.6 & 0.3 & 0.2 \\
\hline
\end{tabular}

Sources: JP Morgan, Bloomberg, Haver Analytics, World Bank.

A. "Rate" refers to the main deposit policy rate in most cases, and the main refinancing rate for the Riksbank. Exchange rate is the J.P. Morgan EM Foreign Exchange Index, EMBI spread is calculated as the average premium paid over a U.S. government bond with comparable 10 maturity, and equity prices are the MSCI Emerging and Frontier index. The bonds spreads are expressed in basis points, while the exchange rate and equities are in percent. 
Figure A.4. NIRP announcements: changes in EMDE financial variables up to one month

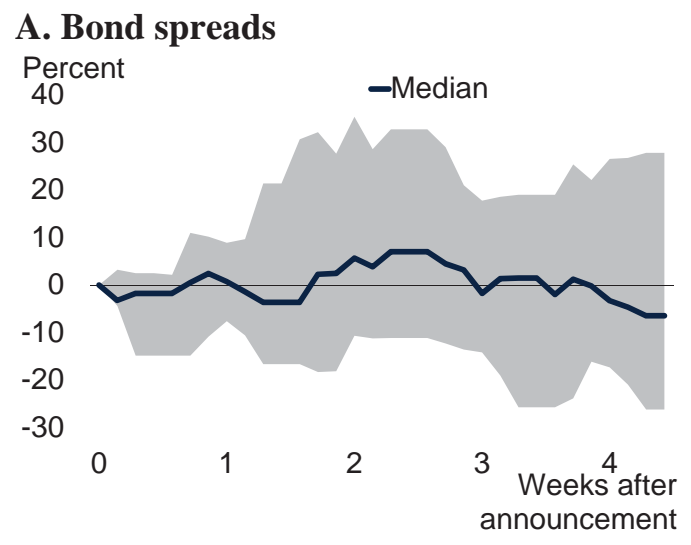

B. Nominal effective exchange rates

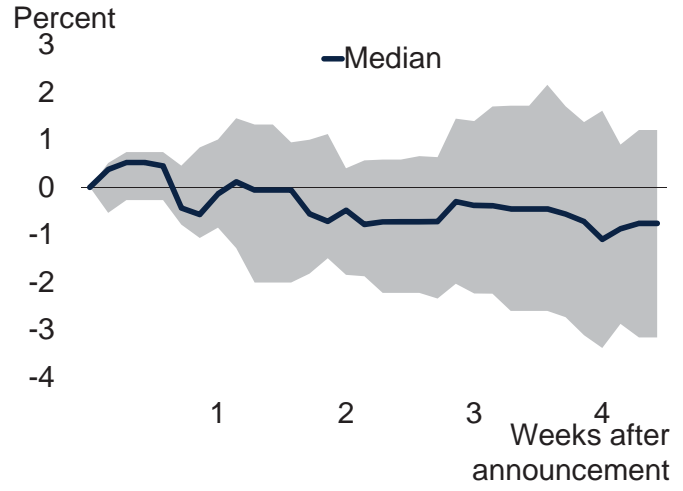

\section{Equities}

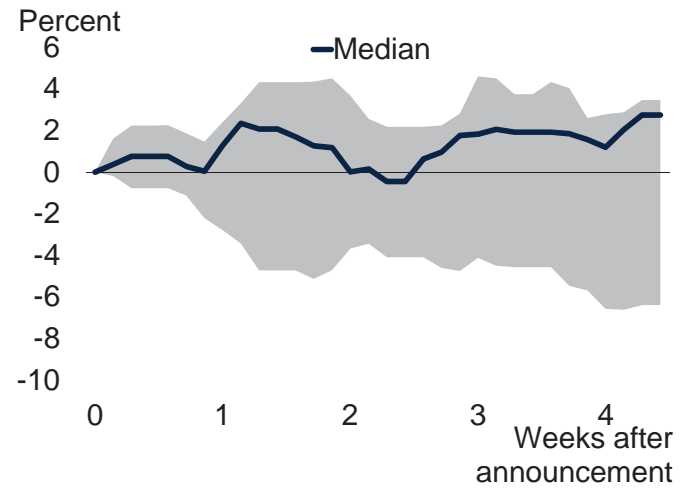

Sources: J.P. Morgan, Bloomberg, Haver Analytics, World Bank.

Notes: Basis points or percent change from closing values on the day before the NIRP announcement. Line indicates median across 6 NIRP announcements. Grey area indicates $10^{\text {th }}$ and $90^{\text {th }}$ percentile range. Each event is extended out for 30 calendar days.

A. Bond spreads are the EMBI Index spread, calculated as the average premium paid over a U.S. government bond with comparable 10 maturity.

B. Effective exchange rate is the J.P. Morgan EM Foreign Exchange Index.

C. Equities are the MSCI Emerging and Frontier index. 


\section{References}

Agarwal, R. and M. Kimball. 2015. "Breaking Through the Zero Lower Bound.” IMF Working Paper: $15 / 224$.

Ahmed, S. and A. Zlate. 2014. "Capital Flows to Emerging Market Economies: A Brave New World?" Journal of International Money and Finance, 48 (B): 221-248.

Alsterlind, J., H. Armelius, D. Forsman, B. Jonsson and A. Wretman. 2015. "How Far Can the Repo Rate be Cut?" Sveriges Riksbank, Economic Commentary: 2015/11.

Altavilla, C., G. Carboni and R. Motto. 2015. "Asset Purchase Programmes and Financial Markets: Lessons from the Euro Area.” European Central Bank, Working Paper Series: 1864.

Armstrong, A., F. Caselli, J. Chadra and W. den Haan. 2015. "Monetary Policy at the Zero Lower Bound." VoxEU, August 2, 2015.

Arslan, Y., B. Guler and T. Taskin. 2015. "Joint Dynamics of House Prices and Foreclosures." Journal of Money, Credit and Banking, 47 (S1): 133-169.

Arslan, Y. and T. Taskin. 2014. "International Evidence on the Interaction between Cross-Border Capital Flows and Domestic Credit Growth." Central Bank of the Republic of Turkey, Working Paper: $14 / 18$.

Arteta, C., M. A. Kose, F. Ohnsorge and M. Stocker. 2015. "The Coming U.S. Interest Rate Tightening Cycle: Smooth Sailing or Stormy Waters?" Policy Research Note: 15/02, World Bank, Washington, D.C.

Baele, L., G. Bakaert, K. Inghelbrecht and M. Wei. 2014. "Flights to Safety." Finance and Economics Discussion Series: 2014-46, Federal Reserve Board, Washington, D.C.

Baffes, J., M. A. Kose, F. Ohnsorge and M. Stocker. 2015. "The Great Plunge in Oil Prices: Causes, Consequences, and Policy Response." Policy Research Note: 15/01, World Bank, Washington, D.C.

Ball, L., B. DeLong, and L. Summers. 2014. "Fiscal Policy and Full Employment." Center on Budget and Policy Priorities, April 2, 2014.

Bank for International Settlements (BIS). 2013. "Asset Encumbrance, Financial Reform and the Demand for Collateral Assets." Committee on the Global Financial System Paper: 49.

Bank of England (BoE). 2013. "Note on Negative Interest Rates for Treasury Committee." May $16,2013$.

Bank of Japan (BoJ). 2016a. "Introduction of Quantitative and Qualitative Monetary Easing with a Negative Interest Rate.” Press release, January 29, 2016.

Bank of Japan (BoJ). 2016b. "Outline of Outright Purchases of Japanese Government Bonds." Press release, April 28, 2016.

Bauer, M. and C. Neely. 2014. "International Channels of the Fed's Unconventional Monetary Policy." Journal of International Money and Finance, 44: 24-46. 
Baumeister, C. and L. Benati. 2013. "Unconventional Monetary Policy and the Great Recession: Estimating the Macroeconomic Effects of a Spread Compression at the Zero Lower Bound." International Journal of Central Banking, 9 (2): 165-212.

Bean, C., C. Broda, T. Ito and R. Kroszner. 2015. "Low for Long? Causes and Consequences of Persistently Low Interest Rates." Geneva Reports on the World Economy 17, International Center for Monetary and Banking Studies.

Bech, M. and A. Malkhozov. 2016. "How Have Central Banks Implemented Negative Policy Rates?" Bank for International Settlements, Quarterly Review, March 2016.

Berends, K., R. McMenamin, T. Plestis and R. Rosen. "The Sensitivity of Life Insurance Firms to Interest Rate Changes.” Economic Perspectives, 2013/Q2, Federal Reserve Bank of Chicago.

Bernanke, B. 2002. "Deflation: Making Sure 'It' Doesn't Happen Here." Remarks by Governor Ben S. Bernanke before the National Economists Club, Washington, D.C.

Bernanke, B. 2005. "The Global Saving Glut and the U.S. Current Account Deficit." Speech at the Sandridge Lecture at the Virginia Association of Economists, Richmond, March 10, 2005.

Bernanke, B. 2016a. "What Tools Does the Fed Have Left? Part 1: Negative Interest Rates." Brookings Institution (blog), March 18, 2016.

Bernanke, B. 2016b. "What Tools Does the Fed Have Left? Part 2: Targeting Longer-Term Interest Rates.” Brookings Institution (blog), March 24, 2016.

Bernanke, B. 2013. The Federal Reserve and the Financial Crisis. Princeton, New Jersey: Princeton University Press.

Bernanke, B. and M. Gertler. 1995. "Inside the Black Box: The Credit Channel of Monetary Policy Transmission." Journal of Economic Perspectives, 9 (4): 27-48.

Bernanke, B., M. Gertler and S. Gilchrist. 1999. "The Financial Accelerator in a Quantitative Business Cycle Framework." Handbook of Macroeconomics, Edited by J. B. Taylor and M. Woodford.

Blanchard, O., D. Furceri, and A. Pescatori. 2014. "A Prolonged Period of Low Real Interest Rates?" In Secular Stagnation: Facts, Causes and Cures, edited by C. Teulings and R. Baldwin. London: Centre for Economic Policy Research.

Blinder, A. S. 2013. After the Music Stopped: The Financial Crisis, the Response, and the Works Ahead. New York: Penguin Press.

Boivin, J., M. Kiley and F. Mishkin. 2010. "How Has the Monetary Transmission Mechanism Evolved Over Time?" Federal Reserve Board, Finance and Economics Discussion Series, 201026.

Borio, C., L. Gombacorta and B. Hofmann. 2015. "The Influence of Monetary Policy on Bank Profitability.” Bank for International Settlements, Working Paper: 514.

Brunnermeier, M. and Y. Koby. 2016. "The 'Reversal Rate': Effective Lower Bound on Monetary Policy." Presentation at the BIS Research Network Meeting, March 14, 2016

Bruno, V. and H. Shin. 2015. "Cross-Border Banking and Global Liquidity." Review of Economic Studies, 82 (2), 535-564. 
Buiter, W. 2009. "Negative Nominal Interest Rates: Three Ways to Overcome the Zero Lower Bound.” NBER Working Paper: 15118.

Buiter, W. 2014. "The Simple Analytics of Helicopter Money: Why It Works - Always." Economics: The Open-Access, Open-Assessment E-Journal, 8 (2014-28): 1-38.

Buiter, W. and N. Panigirtzoglou. 2003. "Overcoming the Zero Bound on Nominal Interest Rates With Negative Interest on Currency: Gesell's Solution." The Economic Journal, 113: 723-746.

Caballero, R., F. Emmanuel and P. Gourinchas. 2008. "An Equilibrium Model of "Global Imbalances' and Low Interest Rates.” American Economic Review, 98 (1): 358-393.

Carney, M. 2016a. "Uncertainty, the Economy and Policy." Speech by Mr. Mark Carney, Governor of the Bank of England, June 30, 2016.

Carney, M. 2016b. "Inflation Report Press Conference.” Bank of England, August 4, 2016.

Caruana, J. 2013. "Hitting the Limits of 'Outside the Box' Thinking? Monetary Policy." in The Crisis and Beyond, Official Monetary and Financial Institutions Forum lecture. London.

Cecchetti, S. 1988. "The Case of the Negative Nominal Interest Rates: New Estimates of the Term Structure of Interest Rates during the Great Depression." Journal of Political Economy, 96 (6): 1111-1141.

Chen, Q., A. Filardo, D. He and F. Zhu. 2011. "International Spillovers of Central Bank Balance Sheet Policies.” Bank for International Settlements, BIS Papers: 66.

Chow, J., F. Jaumotte, S. Park and Y. Zhang. 2015. "Spillovers from Dollar Appreciation.” IMF, Washington, D.C.

Citi. 2016a. "Global Economics Review, Negative Policy Rates - What's Next? Who's Next?" Citi Research, February 11, 2016.

Citi. 2016b. "Global Economics Review, High Time to Get Low: Getting Rid of the Lower Bound on Nominal Interest Rates." Citi Research, April 9, 2015.

Citi. 2016c. "Global Economic Outlook and Strategy.” Citi Research, July 27, 2016.

Claessens, S. 2014. "An Overview of Macroprudential Policy Tools." IMF Working Paper: 14/214, International Monetary Fund, Washington, D.C.

Claessens, S., N. Coleman and M. Donnelly. 2016. "Low-for-long Interest Rates and Net Interest Margins of Banks in Advanced Foreign Economies." Federal Reserve Board, IFDP Notes, April $11,2016$.

Claessens, S., M. A. Kose and M. E. Terrones. 2012. "How Do Business and Financial Cycles Interact?" Journal of International Economics, 87(1): 178-190.

Claessens, S., M. A. Kose, L. Laeven and F. Valencia. 2014. "Financial Crises: Causes, Consequences, and Policy Responses." IMF Publications.

Cliffe, M. 2016. “Negative Rates, Negative Reactions.” VoxEU February 28, 2016.

Cœuré, B. 2015. "Embarking on Public Sector Asset Purchases." Speech at the Second International Conference on Sovereign Bond Markets in Frankfurt, March 10, 2015. 
Cœuré, B. 2016. "Assessing the Implications of Negative Interest Rates." Speech at the Yale Financial Crisis Forum in New Haven, July 28, 2016.

Danmarks Nationalbank (DNB). 2015a. "Suspension of Government Bond Issuance." January 2015.

Danmarks Nationalbank (DNB). 2015b. "Danmarks Nationalbank's Experience with Negative Interest Rates.” Special Topic Article from Danmarks Nationalbank, July 2015.

Danmarks Nationalbank (DNB). 2015c. "Financial Stability, First Half.” June, 2015.

De Rezende, R., D. Kjellberg and O. Tysklind. 2015. "Effects of the Riksbank's Government Bond Purchases on Financial Prices.” Economic Commentaries, 2015/13.

Dedola, L., P. Karadi and G. Lombardo. 2013. "Global Implications of National Unconventional Policies." Journal of Monetary Economics, 60: 66-85.

Dell' Ariccia, G., L. Laeven, and G. Suarez. 2013. "Bank Leverage and Monetary Policy's RiskTaking." IMF Working Paper 13/143, International Monetary Fund, Washington, D.C.

Derviş, K. 2016. “Time for Helicopter Money?” Project Syndicate, March 3, 2016.

Deutsche Bank. 2016a. "Impact of Negative Short Rates and Lower Long Rates on NIMs." Deutsche Bank Markets Research, February 16, 2016.

Deutsche Bank. 2016b. "Helicopters 101: Your Guide to Monetary Financing.” Deutsche Bank Research, Special Report, April 14, 2016.

Di Maggio, M. and M. Kacperczyk. 2016. "The Unintended Consequences of the Zero Lower Bound Policy." Journal of Financial Economics, forthcoming.

Didier, T., M. A. Kose, F. Ohnsorge and L. S. Ye. 2015. "Slowdown in Emerging Markets:

Rough Patch or Prolonged Weakness?" Policy Research Note: 15/04, World Bank.

Draghi, M. 2016. "Introductory Statement to the Press Conference.” April 21, 2016.

Duffee, G. 2013. "Bond Pricing and the Macroeconomy." In Handbook of the Economics of Finance, Edited by George Constantinides, Milt Harris, and Rene Stulz.

Elekdag, S. and Y. Wu. 2011. "Rapid Credit Growth: Boon or Boom-Bust?” IMF Working Paper: 11/241, International Monetary Fund, Washington, D.C.

Elliott, D., C. Jackson, M. Raczko and M. Roberts-Sklar. 2015. "Does oil drive financial market measures of inflation expectations?" Bank of England blog (bankunderground.co.uk), October 2015.

European Banking Authority (EBA). 2016. “2016 EU-Wide Stress Tests Results.” July 29, 2016.

European Central Bank (ECB). 2016a. "Monetary Policy Decisions.” March 10, 2016.

European Central Bank (ECB). 2016b. "Euro Area Bank Lending Survey.” April, 2016.

European Central Bank (ECB). 2016c. "Euro Area Financial Stability Review.” May, 2016.

European Central Bank (ECB). 2016d. "Euro Area Bank Lending Survey.” July, 2016. 
European Commission. 2015. "Survey on Merchants' Costs of Processing Cash and Card Payments: Final Report." European Commission, Directorate-General for Competition, March 2015.

Federal Reserve Board. 2010. "Reducing the IOER Rate: An Analysis of Options." August 5, 2010.

Feldstein, M. 2013. “The Taper Chase.” Project Syndicate, September 30, 2013.

Fink, L. 2016. “To My Fellow Shareholders.” Chairman's Letter, Blackrock.

Folkerts-Landau, D. 2016. "The ECB Must Change Course.” Deutsche Bank Research, June 8, 2016.

Fratzscher, M., M. Lo Duca and R. Straub. 2013. "On the International Spillovers of US Quantitative Easing." ECB Working Paper: 1557.

Friedman, M. 1969. "The Optimum Quantity of Money." in The Optimum Quantity of Money and Other Essays. Chicago: Aldine Publishing Company.

Fukugana, I., N. Kato and J. Koeda. 2015. "Maturity Structure and Supply Factors in Japanese Government Bond Markets." Institute for Monetary and Economic Studies, Discussion Paper: 2015-E-10.

Gagnon, J. 2016. "Quantitative Easing: An Underappreciated Success." Policy Brief: 16-4, Peterson Institute for International Economics.

Gagnon, J., M. Raskin, J. Remache and B. Sack. 2011. "The Financial Market Effects of the Federal Reserve's Large-Scale Asset Purchases." International Journal of Central Banking, March 2011.

Garbade, K and J. McAndrews. 2012. "If Interest Rates Go Negative... Or, Be Careful What You Wish For.” Liberty Street Economics (blog), Federal Reserve Bank of New York, April 29, 2012.

Garbade, K. and J. McAndrews. 2015. "Interest-Bearing Securities when Interest Rates are Below Zero.” Liberty Street Economics (blog), Federal Reserve Bank of New York, May 4, 2015.

Genay, H. and R. Podjasek. 2014. "What is the Impact of a Low Interest Rate Environment on Bank Profitability?" Chicago Fed Letter, 324 (July), Federal Reserve Bank of Chicago.

Geneva Association. 2015. "The Impact of Low Interest Rates on the Insurance Sector and Its Economic Role.” Research Report.

Georgiadis, G. and J. Grab. 2015. "Global Financial Market Impact of the Announcement of the ECB's Extended Asset Purchase Programme." Federal Reserve Bank of Dallas, Globalization and Monetary Policy Institute, Working Paper: 232.

Gibas, N., R. Juks and J. Soderberg. 2015. "Swedish Financial Institutions and Low Interest Rates." Swedish Riksbank, Economic Commentaries, 2015/16.

Gieck, J. 2014. "Unconventional Monetary Policy in an Open Economy.” Deutsche Bundesbank, Discussion Paper: 41/2014.

Glick, R. and S. Leduc. 2012. "Central Bank Announcements of Asset Purchases and the Impact on Global Financial and Commodity Markets." Journal of International Money and Finance, 31 (8): 2078-2101. 
Goldman Sachs. 2016. "Eight Questions on Negative Interest Rates.” Japan Economics Analyst: $16 / 04$

Gombacorta, L., B. Hofmann and G. Peersman. 2014. "The Effectiveness of Unconventional Monetary Policy at the Zero Lower Bound: A Cross-Country Analysis." Journal of Money, Credit and Banking, 46 (4): 615-642.

Goodfriend, M. 2000. "Overcoming the Zero Bound on Interest Rate Policy." Federal Reserve Bank of Richmond, Working Paper: 00-03.

Goodfriend, M. 2002. "Interest on Reserves and Monetary Policy." Federal Reserve Bank of New York, Economic Policy Review, 2002: 77-84.

Hamilton, J. 2016. “Negative Interest Rates.” Econbrowser (blog), February 7, 2016.

Hannoun, H. 2015. "Ultra-Low or Negative Interest Rates: What They Mean for Financial Stability and Growth." Speech at the Eurofi High-Level Seminar, Riga, April 22, 2015.

Hofmann, B., I. Shim and H. S. Shin. 2016. "Sovereign Yields and the Risk-Taking Channel of Currency Appreciation.” BIS Working Paper: 538.

Holston, K., T. Laubach and J. Williams. 2016. "Measuring the Natural Rate of Interest: International Trends and Determinants." Federal Reserve Bank of San Francisco Working Paper: 2016-11.

Huidrom, R., M. A. Kose and F. Ohnsorge. 2016a. "Challenges of Fiscal Policy in Emerging and Developing Economies.” CEPR Discussion Paper: 11347.

Huidrom, R., M. A. Kose, J. Lim, and F. Ohnsorge. 2016b. "Do Fiscal Multipliers Depend on Fiscal Positions?" CEPR Discussion Paper: 11346.

Huttl, P. 2014. "Negative Deposit Rates: The Danish Experience.” Bruegel (blog), June 5, 2014, Brussels.

Ilgmann, C. and M. Menner, 2011, "Negative Nominal Rates: History and Current Proposals." International Economics and Economic Policy, 8: 383-405.

International Monetary Fund (IMF). 2014. "World Economic Outlook: Legacies, Clouds, Uncertainties." October 2014, IMF, Washington D.C.

International Monetary Fund (IMF). 2015a. "Spillover Report.” July 2015. IMF, Washington, DC. International Monetary Fund (IMF). 2015b. “Article IV Consultation, Sweden.” December 2015, IMF, Washington, D.C.

International Monetary Fund (IMF). 2015c. "Article IV Consultation, Switzerland.” May 2015, IMF, Washington, D.C.

International Monetary Fund (IMF). 2016a. "Article IV Consultation, Euro Area: Selected Issues Papers.” June 2016, IMF, Washington, D.C.

International Monetary Fund (IMF). 2016b. “Article IV Consultation, Euro Area, July 2016.” IMF, Washington, D.C.

International Monetary Fund (IMF). 2016c. "Global Financial Stability Report.” April 2016, IMF, Washington, D.C. 
Jackson, H. 2015. "The International Experience with Negative Policy Rates." Bank of Canada Staff Discussion Paper: 2015-13.

Japan Ministry of Finance. 2016. "JGB Issuance Plan for Fiscal Year 2016.” Newsletter, January $2,2016$.

Jimenez, G., S. Ongena, L. Peydro and J. Saurina. 2014. "Hazardous Times for Monetary Policy: What Do Twenty-Three Million Bank Loans Say About the Effects of Monetary Policy on Credit Risk-Taking?" Econometrica, 82 (2): 463-505.

J.P. Morgan. 2016. "Negative Policy Rates: The Bound is Lower than You Think.” Special Report, February 9, 2016.

Kapetanios, G., H. Mumtaz, I. Stevens and K. Theodoridis. 2012. "Assessing the Economy-Wide Effects of Quantitative Easing." The Economic Journal, 122: 316-347.

Kocherlakota, N. 2016a. "Use the Power of Negative Rates." Bloomberg View (blog), March 10, 2016.

Kocherlakota, N. 2016b. "Sluggish Inflation Expectations: A Markov Chain Analysis." NBER Working Paper: 22009.

Kose, M. A. and M. Terrones. 2015. Collapse and Revival: Understanding Global Recessions and Recoveries. International Monetary Fund, Washington, D.C.

Kozicki, S., E. Santor and L. Suchanek. 2011. "Unconventional Monetary Policy: The International Experience with Central Bank Asset Purchases." Bank of Canada Review, Spring 2011.

Krishnamurthy, A. and A. Vissing-Jorgensen. 2011. "The Effects of Quantitative Easing on Interest Rates." Brookings Papers on Economic Activity, Fall 2011.

Lane, P. and P. Mcquade. 2014. "Domestic Credit Growth and International Capital Flows." Scandinavian Journal of Economics, 116 (1): 218-252.

Lim, J., S. Mohapatra and M. Stocker. 2014. "Tinker, Taper, QE, Bye? The Effect of Quantitative Easing on Financial Flows to Developing Countries.” The World Bank, Policy Research Working Paper: 6820.

Lo, A. 2012. "Reading about the Financial Crisis: A 21-Book Review." Massachusetts Institute of Technology, mimeo.

Malinovskaya, A. and D. Wessel. 2016. "Did Negative Rates in Europe Trigger Massive Cash Hoarding?” Brookings Institution (blog), June 17, 2016.

Mankiw, G. 2009. "It May be Time for the Fed to Go Negative.” New York Times, April 19, 2009.

McAndrews, J. 2015. "Negative Nominal Central Bank Policy Rates: Where Is the Lower Bound?" Speech at the University of Wisconsin in Madison, May 8, 2015.

Mendoza, E. 2010. "Sudden Stops, Financial Crises, and Leverage." American Economic Review, 100: 1941-1966.

Meggyesi, P. 2010. "Reflections on Negative Interest Rates in Switzerland.” J.P. Morgan, May 14, 2010. 
Mian, A., A. Sufi, and E. Verner. 2015. "Household Debt and Business Cycle Worldwide.” NBER Working Paper: 21581.

Mishkin, F. 1995. "Symposium on the Monetary Transmission Mechanism." Journal of Economic Perspectives, 9 (4): 3-10.

MNB (Central Bank of Hungary). 2016. "Press Release on the Monetary Council Meeting." March $22,2016$.

Moore, J., N. Sunwoo, S. Myeongguk and A. Tepper. 2013. "Estimating the Impact of U.S. LSAPs on Emerging Market Economies' Local Currency Bond Markets." Federal Reserve Bank of New York, Staff Report: 595.

Morgan Stanley. 2016a. "Negative Rates: A 'Dangerous Experiment' with Diminishing Positive Impact?” Morgan Stanley Research, February 17, 2016.

Morgan Stanley. 2016b. "Central Banks: What's Left in the Toolkit?” Morgan Stanley Research, February 22, 2016.

Nieder, D. 2013. "10 Years of Low Interest Rate Environment-Experiences from the Japanese Life Insurance Market.” GenRe Insurance Issues Series, April 2013.

Perez-Segura, A. and R. Vigfusson. 2016. "The relationship between oil prices and inflation compensation.” IFDP Notes, Board of Governors of the Federal Reserve System, April 2016.

Rachel, L. and T. Smith. 2015. "Secular Drivers of the Global Real Interest Rate." Bank of England Staff Working Paper: 571.

Rey, H. 2015. "International Credit Channel and Monetary Policy Autonomy." Paper prepared for the 15th Jacques Polak IMF Annual Research Conference.

Riksbank. 2015. "Riksbank Cuts Repo Rate to -0.10 per cent, Buys Government Bonds for SEK 10 billion and is Prepared to Do More at Short Notice." Press Release, February 12, 2015.

Riksbank. 2016. "Repo Rate Cut to -0.50 per cent.” Press Release, February 11, 2016.

Roach, S. 2016. “Central Banking Goes Negative.” Project Syndicate, February 18, 2016.

Rogoff, K., 2014. "Costs and Benefits to Phasing out Paper Currency." NBER Working Paper: 20126.

Rohde, L. 2015. "Monetary Policy, Foreign Exchange Intervention and GDP Growth Seen Rising." Speech by Mr. Lars Rohde, Governor of the DNB, Copenhagen, March 25, 2015.

Rostagno, M., U. Bindseil, A. Kamps, W. Lemke, T. Sugo and T. Vlassopoulos. 2016. "Breaking through the zero line: The ECB's Negative Interest Rate Policy." Presentation at Brookings Institution seminar Negative interest rates: Lessons learned...so far, Washington D.C., June 6, 2016.

Shin, H. S. 2016. "Bank Capital and Monetary Policy Transmission." Panel Remarks at the ECB and Its Watchers XVII Conference, Frankfurt, April 7, 2016.

Stiglitz, J. 2016. “What's Wrong with Negative Rates?” Project Syndicate, April 13, 2016.

Summers, L. H. 2014. "U.S. Economic Prospects: Secular Stagnation, Hysteresis, and the Zero Lower Bound." Business Economics, Vol. 49, No. 2. 
Sussman, N. and O. Zohar. 2015. "Oil prices, inflation expectations, and monetary policy." VoxEU blog, September 2015.

Swiss National Bank (SNB). 2015. “Quarterly Bulletin.” June 2015.

Swiss National Bank (SNB). 2016. “Monetary Policy Assessment.” March 2016.

Svensson, L.E.O, 2015. "Negative Interest Rates: Helpful or Harmful?" Goldman Sachs Global Macro Research Top of Mind, No. 32, February 2015.

Tong, H. 2016. "Negative Interest Rate Policy and Bank Deposit Rate.” Japan Selected Issues Papers, IMF Country Report: 16/268.

Viñals, J., S. Gray, and K. Eckhold .2016. "The Broader View: The Positive Effects of Negative Nominal Interest Rates.” International Monetary Fund, iMFdirect, Blog, April 10, 2016.

Waller, C. J. 2016. "Negative Interest Rates: A Tax in Sheep's Clothing.” Federal Reserve Bank of St. Louis, On the Economy (blog), May 2, 2016.

Walsh, C. 2010. "Monetary Theory and Policy." Third Edition, The MIT Press, Cambridge, Massachusetts.

Weale, M. 2016. "Unconventional Monetary Policy." Speech Given at the University of Nottingham, March 8, 2016.

Weale, M. and T. Wieladek. 2016. "What are the Macroeconomic Effects of Asset Purchases?" Journal of Monetary Economics, 79: 81-93.

Wessel, D. and P. Olson. 2016. "Are Negative Rates a "Calamitous Misadventure"? ECB Economists Say No" Brookings Institution (blog), June 16, 2016.

White, W. 2012. "Ultra Easy Monetary Policy and the Law of Unintended Consequences." Federal Reserve Bank of Dallas, Globalization and Monetary Policy Institute. Working Paper: 126.

White, W. 2014. "The Monetary System is Dangerously Unanchored." Interview with Finanz und Wirtschaft, December 19, 2014.

Williams, J. 2014. "Monetary Policy at the Zero Lower Bound: Putting Theory into Practice." Hutchins Center on Fiscal and Monetary Policy at Brookings, January 16, 2014.

World Bank. 2015a. "Global Economic Prospects: The Global Economy in Transition.” June 2015. World Bank. 2015b. "Global Economic Prospects: Having Fiscal Space and Using It.” January 2015.

World Bank. 2016a. "Global Economic Prospects: Divergences and Risks.” June 2016.

World Bank. 2016b. “Global Economic Prospects: Spillovers amid Weak Growth.” January 2016.

Zurbrugg, F. 2015. “A New Premise for SNB Monetary Policy?” Speech by Mr. Fritz Zurbrugg, Vice Chairman of the SNB Governing Board, KOF Forecast Conference, Berne, October 1, 2015. 